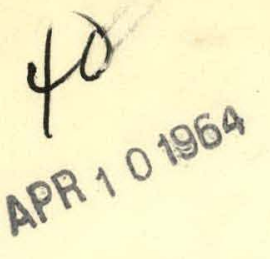

Classification cancelled (tongang

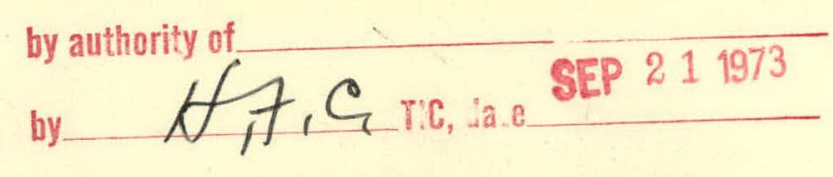

UNCLASSIFIED
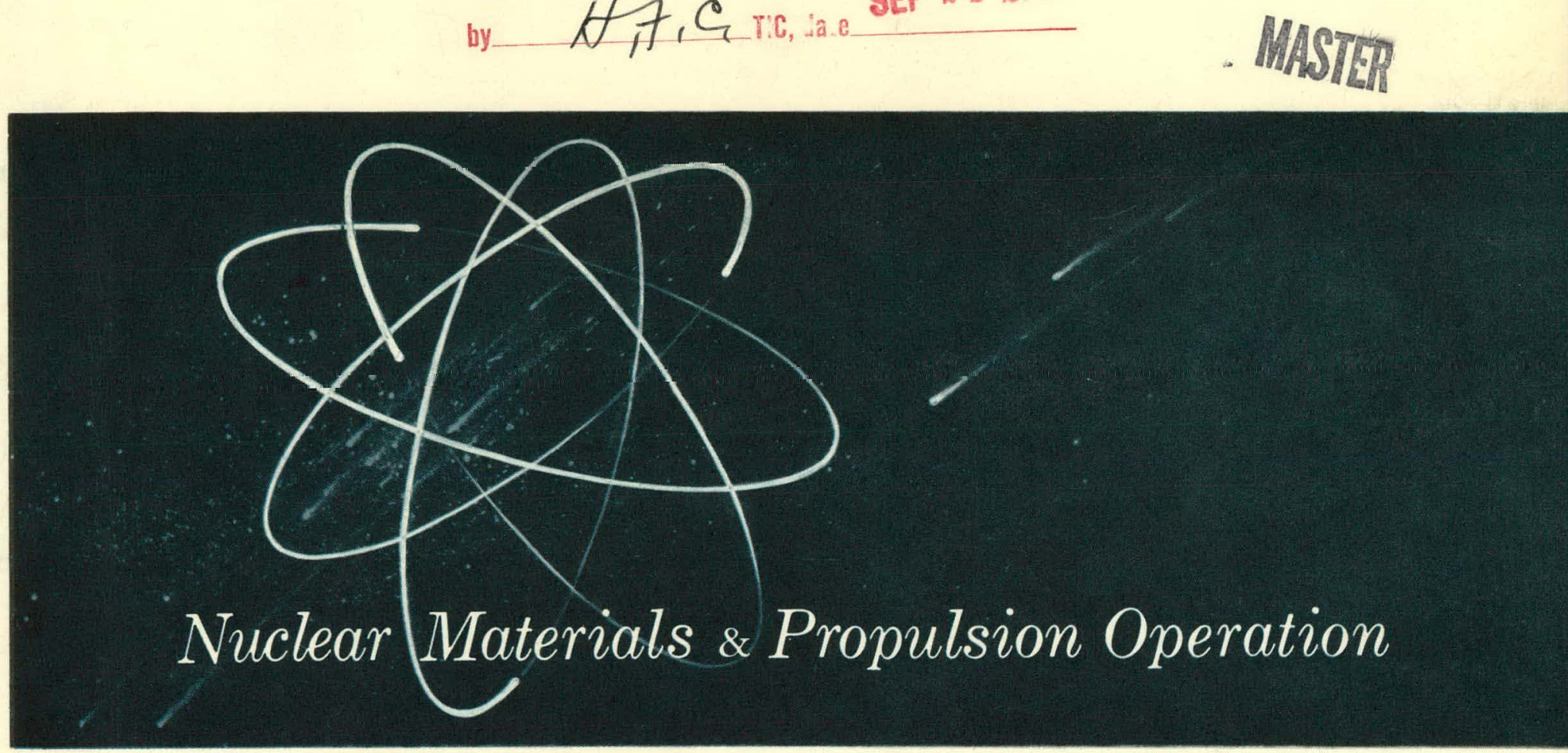

\title{
THE $\mathrm{UO}_{2}-\mathrm{UO}_{3}-\mathrm{Y}_{2} \mathrm{O}_{3}$ SYSTEM AND EVALUATION OF THE $\mathrm{UO}_{2.9} \cdot 3 \mathrm{Y}_{2} \mathrm{O}_{3}$ COMPOSITION
}

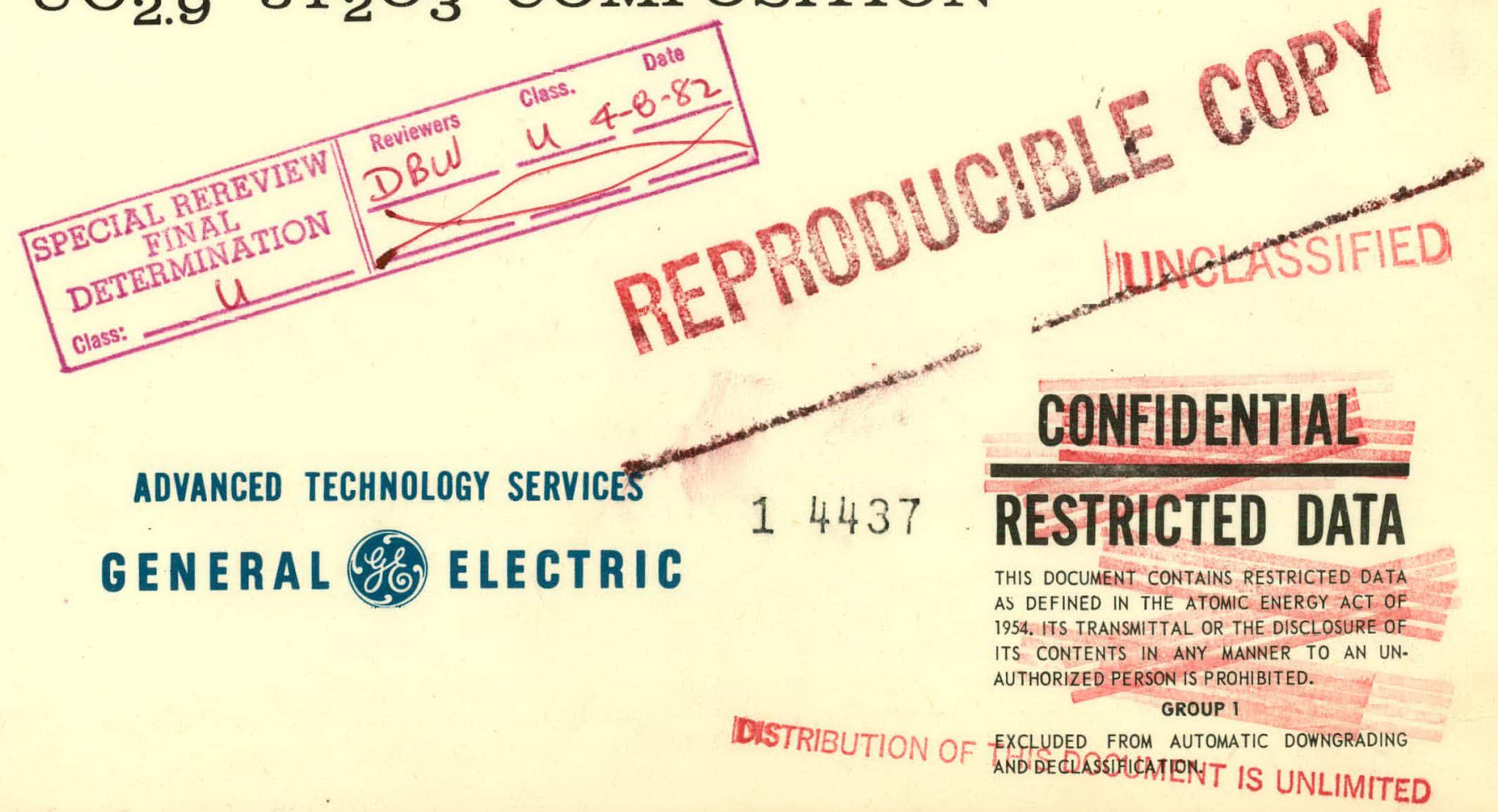




\section{DISCLAIMER}

This report was prepared as an account of work sponsored by an agency of the United States Government. Neither the United States Government nor any agency Thereof, nor any of their employees, makes any warranty, express or implied, or assumes any legal liability or responsibility for the accuracy, completeness, or usefulness of any information, apparatus, product, or process disclosed, or represents that its use would not infringe privately owned rights. Reference herein to any specific commercial product, process, or service by trade name, trademark, manufacturer, or otherwise does not necessarily constitute or imply its endorsement, recommendation, or favoring by the United States Government or any agency thereof. The views and opinions of authors expressed herein do not necessarily state or reflect those of the United States Government or any agency thereof. 


\section{DISCLAIMER}

Portions of this document may be illegible in electronic image products. Images are produced from the best available original document. 


\section{LEGAL NOTICE}

This report was prepared as an account of Government sponsored work. Neither the United States, nor the Commission, nor any person acting on behalf of the Commission:

A. Makes any warranty or representation, expressed or implied, with respect to the accuracy, completeness, or usefulness of the information contained in this report, or that the use of any information, apparatus, material, method, or process disclosed in this report may not infringe privately owned rights; or

B. Assumes any liabilities with respect to the use of, or for damages resulting from the use of any information, apparatus, material, method, or process disclosed in this report.

As used in the above, "person acting on behalf of the Commission" includes any employee or contractor of the Commission, or employee of such contractor, to the extent that such employee or contractor of the Commission, or employee of such contractor prepares, disseminates, or provides access to, any information pursuant to his employment or contract with the Commission or his employment with such contractor. 


\section{CONFDENA \\ GEMP - 263 \\ C-44a Nuclear Technology - Materials M-3679 (33rd Edition) \\ UNCLASSIFIED}

\section{THE $\mathrm{UO}_{2}-\mathrm{UO}_{3}-\mathrm{Y}_{2} \mathrm{O}_{3}$ SYSTEM \\ AND EVALUATION OF THE $\mathrm{UO}_{2.9} \cdot 3 \mathrm{Y}_{2} \mathrm{O}_{3}$ COMPOSITION}

\author{
J.F. White \\ E. F. Juenke \\ D.E. Burgbacher
}

March 31, 1964
This report was prepared as an account of work sponsored by the United States Government. Neither the United States nor the United States Atomic Energy Commission, nor any of their employees, nor any of their contractors, subcontractors, or their employees, makes any warranty, express or implied, or assumes any legal liability or responsibility for the accuracy, completeness or usefulness of any information, apparatus, product or process disclosed, or represents that its use would not infringe privately owned rights.

\section{NUCLEAR MATERIALS and PROPULSION -OPERATION \\ ADVANCED TECHNOLOGY SERVICES

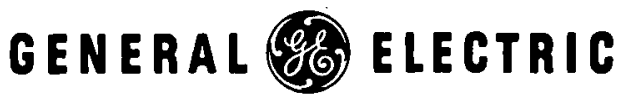

Cincinnati 15, Ohio

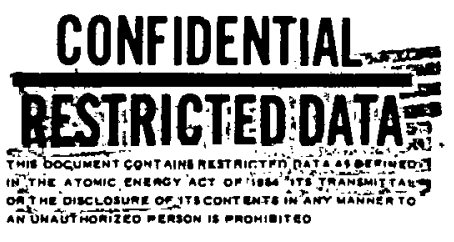

UNCLASSIFIED 
EXTERNAL

AEC Headquarters

E. M. Douthett

I. Hoffman

T. W. McIntosh

R. E. Pahler

W. S. Scheib

F. C. Schwenk

J. M. Simmons

W. R. Voigt

G. W. Wensch

M. J. Whitman

AEC, OROO

D. F. Cope (3)

D. S. Zachry, Jr.

AEC, CANEL Project Office

A. J. Alexander

AFC, CAO

C. L. Karl

J. F. Weissenberg

AEC, SAN

Lt. Col. J. B. Radcliffe, Jr. General Atomic

G. B. Engle

M. V. Goeddel

Pratt and Whitney Aircraft (CANEL)

L. M. Raring (3)

Argonne National Laboratory

R. Noland

\section{INTERNAL}

E. A. Altken

W. G. Baxter

J. C. Blake

B. Bonini

H. C. Brassfield

R. W. Brisken

D. E. Burgbacher

J. J. Cadwell, HAPO

V. P. Calkins

B. A. Chandler

C. L. Chase

C. G. Collins

E. S. Collins

J. F. Collins

P. K. Conn

J. B. Conway

E. B. Delson

H. S. Edwards
E. W. Filer

R. E. Fryxell

E. S. Funston

M. B. Goldsteln

G. F. Hamby

J. O. Hibbits

L. D. Jordan

R. A. Joseph

E. F. Juenke

G. Korton

M. C. Leverett, HAPO

W. H. Long

R. A. Lutter

J. W. Morfitt

J. Moteff

R. E. Motsinger

G. T. Muehlenkamp
ORNL

R. E. Blanco

R. E. Clausing

D. A. Douglas, Jr.

W. R. Grimes

W. O. Harms

W. D. Manly

G. B. Marrow

A. J. Miller

N. W. Rosenthal

BMI

R. W. Dayton

LASL

R. D. Baker

Lawrence Radiation Laboratory

R. E. Batzel

C. Cline

A. J. Rothman

NASA Headquarters

J. J. Lynch

NASA Lewis Research Center

J. W. Creagh

N. Saunders

N. R. Thielke

Westinghouse, Astronuclear Lab.

D. C. Goldberg

Westinghouse (NASA)

D. E. Thomas

Atomics International

R. Balent
C. E. Niemeyer

W. E. Nlemuth

R. E. Nightingale, HAPO

G. W. Pomeroy

W. Z. Prlckett

R. C. Rau

F. C. Robertshaw

E. J. Schmldt, ATS

M. T. Schoenberger

R. J. Spera

G. Thornton

P. P. Turner

F. O. Urban

H. E. Wagner

J. F. White

O. G. Wolke

R. E. Wood

Llbrary (10) 


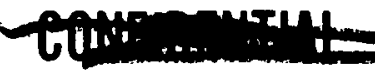

\section{ABSTRACT}

The tentative $\mathrm{UO}_{2}-\mathrm{UO}_{3}-\mathrm{Y}_{2} \mathrm{O}_{3}$ ternary phase equilibrium diagram was developed for temperatures to $1700^{\circ} \mathrm{C}$. Four phases were identified in the system at the temperatures between $1000^{\circ} \mathrm{C}$ and $1700^{\circ} \mathrm{C}$ : (1) $\mathrm{U}_{3} \mathrm{O}_{8}$, (2) a face-centered cubic solid solution, (3) a body-centered cubic solid solution, and (4) a rhombohedral phase of the composition $(\mathrm{U}, \mathrm{Y})_{7} \mathrm{O}_{12}$ ranging from 52.5 to 75 mole percent $\mathrm{Y}_{2} \mathrm{O}_{3}$.

The rhombohedral phase $\left(\mathrm{UO}_{2} \cdot 9^{\cdot} \cdot 3 \mathrm{Y}_{2} \mathrm{O}_{3}\right)$ was selected for detailed investigation as a nuclear fuel because it showed unusually good stability in air at elevated temperatures. Preparation, fabrication, and properties of this material are described including use of the material as a cladding on BeO tubes for high specific-power thermal-reactor fuel elements.

Property measurements of the $\mathrm{UO}_{2 .} \cdot 3 \mathrm{Y}_{2} \mathrm{O}_{3}$ composition show that it can be used in air for 500 hours at $1700^{\circ} \mathrm{C}$ without appreciable loss of $\mathrm{UO}_{2}$. The strength properties are about the same as those of $\mathrm{UO}_{2}$. Thermal expansion of the material is very similar to $\mathrm{BeO}$ which suggests its use on $\mathrm{BeO}$ as a fuel. Electrical conductivity of the material was found to be mainly electronic below $1500^{\circ} \mathrm{C}$. Thermal conductivity is slightly lower than that of $\mathrm{UO}_{2}$. 


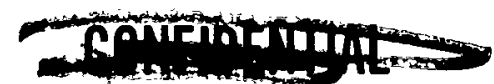

\section{CONTENTS}

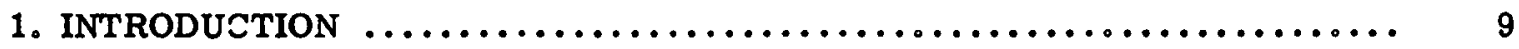

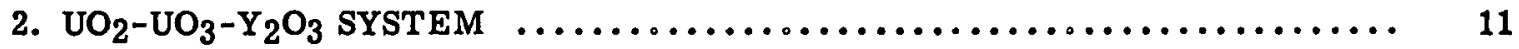

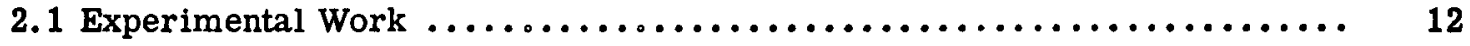

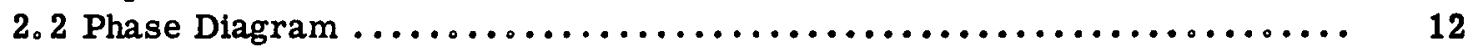

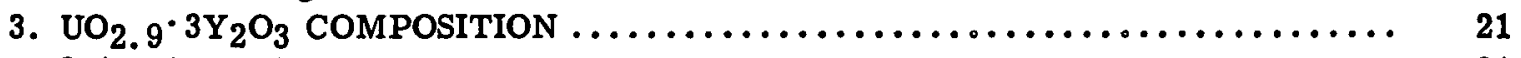

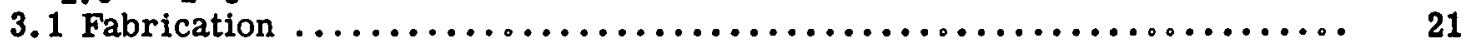

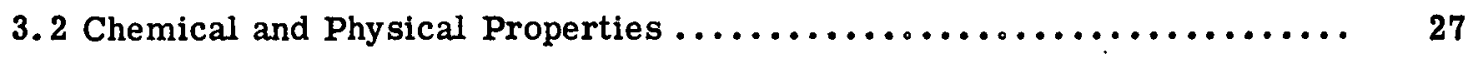

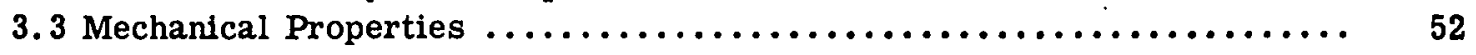

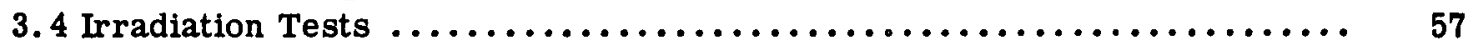

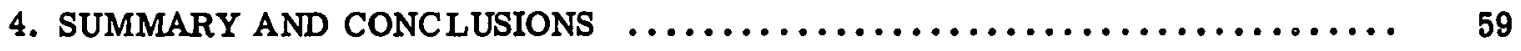

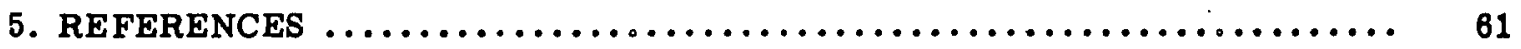




\section{FIGURES}

2.1 - The $\mathrm{UO}_{2}-\mathrm{UO}_{3}-\mathrm{Y}_{2} \mathrm{O}_{3}$ ternary diagram from $1000^{\circ}$ to $1700^{\circ} \mathrm{C} \ldots \ldots \ldots \ldots$

2.2 - The $\mathrm{UO}_{2}-\mathrm{UO}_{3}-\mathrm{Y}_{2} \mathrm{O}_{3}$ system (low-temperature oxidation below $1000^{\circ} \mathrm{C}$ ) ...

2.3 - Comparison of equivalent cubic lattice parameter of $\left(U_{1-X}, Y_{X}\right) O_{2.25-y}$ composition as a function of cation fraction of yttrium $\ldots \ldots \ldots \ldots \ldots \ldots$

2.4 - Lattice parameters of BCC solid solution of $\mathrm{UO}_{2}-\mathrm{Y}_{2} \mathrm{O}_{3} \ldots \ldots \ldots \ldots \ldots \ldots$

3.1 - Effect of grinding media-to-powder ratio on sintered density

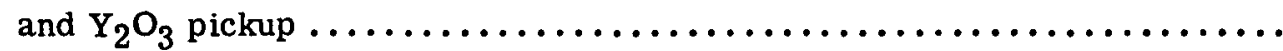

3. 2 - Effect of water-to-powder ratio on sintered density and $\mathrm{Y}_{2} \mathrm{O}_{3}$ pickup ....

3.3 - Effect of milling time on sintered density and $\mathrm{Y}_{2} \mathrm{O}_{3}$ pickup...........

3.4 - Extrusion pressure versus extrusion flow rate of $\mathrm{UO}_{2+\mathrm{x}} \cdot 3 \mathrm{Y}_{2} \mathrm{O}_{3}$ dispersed in a solution of 20 percent polyacrylamide in $\mathrm{H}_{2} \mathrm{O} \ldots \ldots \ldots \ldots$.

3.5 - Extrusion pressure versus extrusion flow rate of $\mathrm{UO}_{2+\mathrm{x}} \cdot 3 \mathrm{Y}_{2} \mathrm{O}_{3}$ dispersed in a solution of 15 percent polyacrylamide, 20 percent

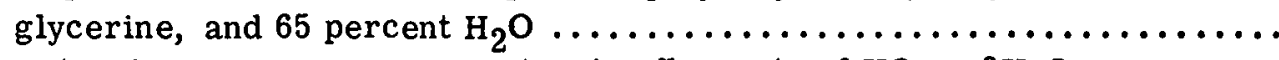

3. 6 - Extrusion pressure versus extrusion flow rate of $\mathrm{UO}_{2+x^{\cdot}} 3 \mathrm{Y}_{2} \mathrm{O}_{3}$ dispersed in a solution of 15 percent hydroxy-methyl cellulose, 20 percent glycerine, and 65 percent $\mathrm{H}_{2} \mathrm{O} \ldots \ldots \ldots \ldots \ldots \ldots \ldots \ldots \ldots \ldots$

3. 7 - Extrusion pressure versus extrusion flow rate of $\mathrm{UO}_{2+\mathrm{x}} \cdot 3 \mathrm{Y}_{2} \mathrm{O}_{3}$ dispersed in a solution of 4 percent polyacrylamide, 10 percent hydroxy-methyl cellulose, 6.7 percent glycerine, and 79.3 percent $\mathrm{H}_{2} \mathrm{O}$..

3. 8 - Coextruded $\mathrm{BeO}-\mathrm{UO}_{2 .} \cdot 9^{\cdot} 3 \mathrm{Y}_{2} \mathrm{O}_{3}$ tube dip coated with BeO cladding

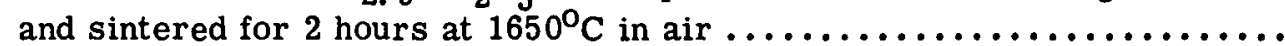

3. 9 - Microstructure of milled $\mathrm{UO}_{2.9} \cdot 3 \mathrm{Y}_{2} \mathrm{O}_{3}$ powder sintered in oxygen

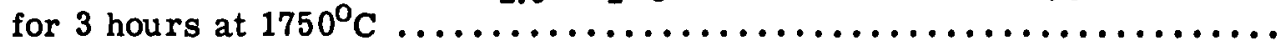

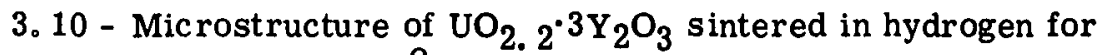

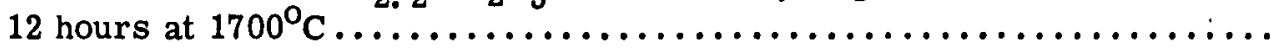

3. 11 - Microstructure of $\mathrm{UO}_{2} .2 \cdot 3 \mathrm{Y}_{2} \mathrm{O}_{3}$ sintered in hydrogen for 12 hours at $1700^{\circ} \mathrm{C}$ and then normalized in air for 60 hours at $1450^{\circ} \mathrm{C} \ldots \ldots \ldots \ldots$

3. 12 - Microstructure of $\mathrm{UO}_{2} .9^{\cdot} 3 \mathrm{Y}_{2} \mathrm{O}_{3}$ sintered in oxygen for 3 hours at $1750^{\circ} \mathrm{C}$. .

3. 13 - Microstructure of oxygen-sintered $\mathrm{UO}_{2} .9^{\cdot} \cdot 3 \mathrm{Y}_{2} \mathrm{O}_{3}$ after heating for

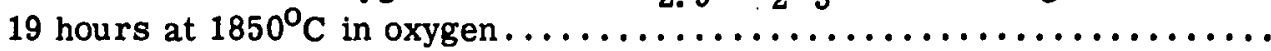

3. 14 - Microstructure of oxygen-sintered $\mathrm{UO}_{2} .9^{\cdot} \cdot 3 \mathrm{Y}_{2} \mathrm{O}_{3}$ after heating for

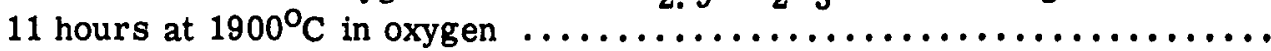

3. 15 - Microstructure of oxygen-sintered $\mathrm{UO}_{2.9} \cdot 3 \mathrm{Y}_{2} \mathrm{O}_{3}$ after heating for

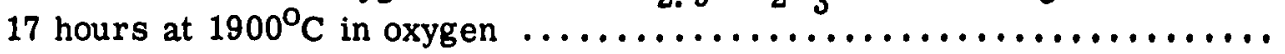

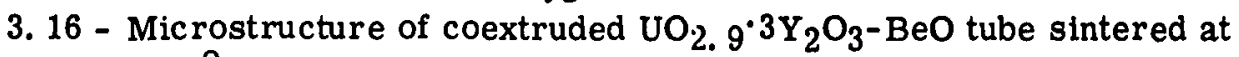

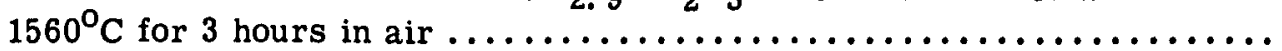

3. 17 - Microstructure of coextruded $\mathrm{UO}_{2.9} \cdot 3 \mathrm{Y}_{2} \mathrm{O}_{3}-\mathrm{BeO}$ tube sintered at $1560^{\circ} \mathrm{C}$ for 3 hours in air and heated for 224 hours at $1560^{\circ} \mathrm{C}$ in dry air ...

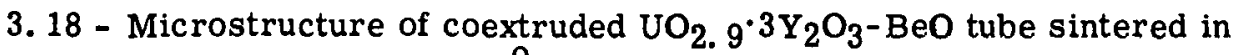
air for 2 hours at $1600^{\circ} \mathrm{C}$ 


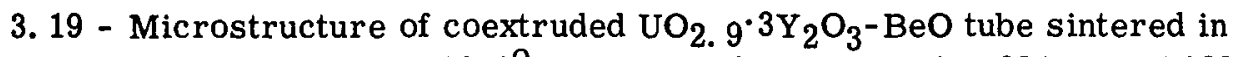
air for 2 hours at $1600^{\circ} \mathrm{C}$ and heated in dry air for 82 hours at $1600^{\circ} \mathrm{C} \ldots$.

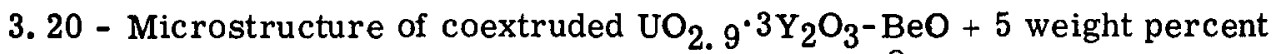
$\mathrm{ZrO}_{2}$ tube sintered in air for 2 hours at $1600^{\circ} \mathrm{C} \ldots \ldots \ldots \ldots \ldots \ldots \ldots$

3. 21 - Mic rostructure of coextruded $\mathrm{UO}_{2} .9 \cdot 3 \mathrm{Y}_{2} \mathrm{O}_{3}-\mathrm{BeO}+5$ weight percent $\mathrm{ZrO}_{2}$ tube sintered in air for 2 hours at $1600^{\circ} \mathrm{C}$ and heated in dry air for

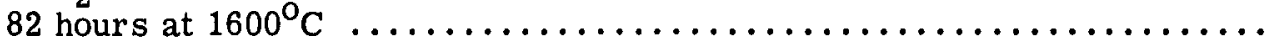

3. 22 - Coextruded $\mathrm{BeO}-\mathrm{UO}_{2} .9^{\cdot} 3 \mathrm{Y}_{2} \mathrm{O}_{3}$ tube dip coated with $\mathrm{BeO}$ cladding

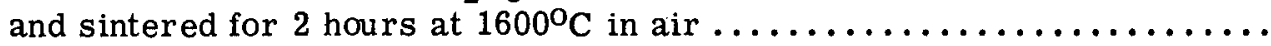

3.23 - Coextruded dip coated $\mathrm{BeO}-\mathrm{UO}_{2.9} \cdot 3 \mathrm{Y}_{2} \mathrm{O}_{3}$ tube sintered for 2 hours at $1600^{\circ} \mathrm{C}$ in air and heated for 979 hours in dry air at $1370^{\circ} \mathrm{C} \ldots \ldots \ldots \ldots . . . .37$

3. 24 - Thermal expansion of $\mathrm{BeO}$ and $\mathrm{UO}_{2 .} \cdot 9^{\cdot} 3 \mathrm{Y}_{2} \mathrm{O}_{3}$ in air $\ldots \ldots \ldots \ldots \ldots \ldots \ldots . . \ldots$

3.25 - Thermal expansion curves for hydrogen-sintered samples measured in air to $1200^{\circ} \mathrm{C}$ and $1425^{\circ} \mathrm{C} \ldots \ldots \ldots \ldots \ldots \ldots \ldots \ldots \ldots \ldots \ldots \ldots \ldots$

3. 26 - Linear thermal expansion of oxygen-sintered sample measured

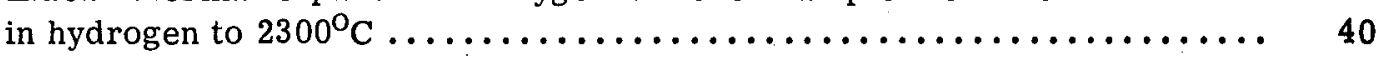

3. 27 - Thermal expansion of reduced $\mathrm{UO}_{2+\mathrm{x}} \cdot 3 \mathrm{Y}_{2} \mathrm{O}_{3}, \mathrm{UO}_{2}$, and $\mathrm{Y}_{2} \mathrm{O}_{3}$

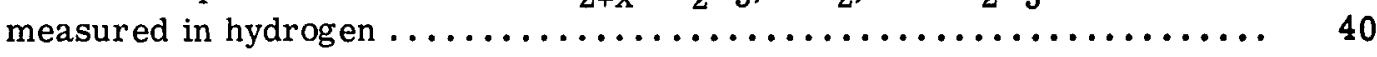

3.28 - Thermal conductivity versus mean temperature for $\mathrm{UO}_{2+\mathrm{x}} \cdot 3 \mathrm{Y}_{2} \mathrm{O}_{3}$ and $\mathrm{UO}_{2} \cdot 41$

3. 29 - Resistivity as a function of temperature for oxidized and reduced

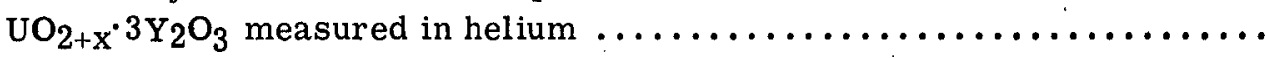

3. 30 - Schematic diagram of apparatus for electrical resistivity and

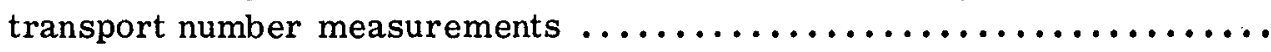

3. 31 - Electrical conductivity as a function of reciprocal temperature for two compositions in the $\mathrm{UO}_{2}-\mathrm{UO}_{3}-\mathrm{Y}_{2} \mathrm{O}_{3}$ system $\ldots \ldots \ldots \ldots \ldots \ldots \ldots$

3.32 - Electrical conductivity versus reciprocal temperature for $2 \mathrm{UO}_{3-\mathrm{x}} \cdot 3 \mathrm{Y}_{2} \mathrm{O}_{3}$ (initially $\left.\sim 50 \% \mathrm{FCC}, 50 \% \mathrm{Rh} \mathrm{I}\right) \ldots \ldots \ldots \ldots \ldots \ldots \ldots \ldots . \ldots \ldots$

3.33 - Ionic conductivity as a function of temperature for $2 \mathrm{UO}_{3-\mathrm{x}} \cdot 3 \mathrm{Y}_{2} \mathrm{O}_{3}$

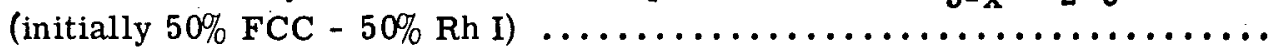

3.34 - Electrical conductivity versus reciprocal temperature for

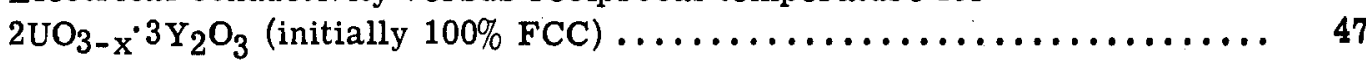

3. 35 - Ionic conductivity as a function of temperature for $2 \mathrm{UO}_{3}-\mathrm{x}^{\cdot} \cdot 3 \mathrm{Y}_{2} \mathrm{O}_{3}$

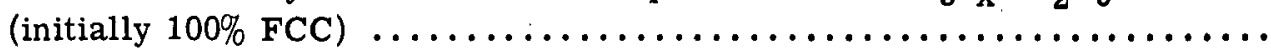

3.36 - Thermogravimetric analysis of $2 \mathrm{UO}_{3-\mathrm{x}} \cdot 3 \mathrm{Y}_{2} \mathrm{O}_{3}$ (FCC) showing reversible oxygen dissociation upon thermal cycling in air ........... 48

3.37 - Vapor pressure of $\mathrm{UO}_{3}$ over $\mathrm{UO}_{2+\mathrm{x}} \cdot 3 \mathrm{Y}_{2} \mathrm{O}_{3} \ldots \ldots \ldots \ldots \ldots \ldots \ldots \ldots \ldots \ldots \ldots$

3.38 - Enthalpy of $\mathrm{UO}_{2+\mathrm{x}} \cdot 3 \mathrm{Y}_{2} \mathrm{O}_{3}$ and $\mathrm{UO}_{2}$ as a function of temperature ........ 51

3.39 - Transgranular fracture of $\mathrm{UO}_{2} .9 \cdot 3 \mathrm{Y}_{2} \mathrm{O}_{3}$, sintered in oxygen for 3 hours at $1750^{\circ} \mathrm{C}$.

3. 40 - Fracture pattern of UOX-grade beryllia plus 0.5 weight percent $\mathrm{MgO}$, sintered in hydrogen for 3 hours at $1540^{\circ} \mathrm{C} \ldots \ldots \ldots \ldots \ldots \ldots \ldots \ldots$

3. 41 - Fracture pattern of alumina (Linde A) plus 0.25 weight percent $\mathrm{MgO}$, sintered in hydrogen for 10 hours at $1700^{\circ} \mathrm{C} \ldots \ldots \ldots \ldots \ldots \ldots \ldots \ldots$

3. 42 - Dynamic modulus of elasticity versus temperature for $\mathrm{UO}_{2} .9^{\cdot} 3 \mathrm{Y}_{2} \mathrm{O}_{3} \ldots \ldots$

3.43 - Dynamic shear modulus versus temperature for $\mathrm{UO}_{2 .} 9^{\cdot 3 \mathrm{Y}_{2} \mathrm{O}_{3} \ldots \ldots . . . .}$

3.44 - Calculated Poisson's ratio versus temperature for $\mathrm{UO}_{2 .} \cdot{ }^{\cdot} 3 \mathrm{Y}_{2} \mathrm{O}_{3} \ldots \ldots \ldots$ 


\section{TABLES}

2.1 - Phase relationships and oxygen-to-uranium ratios in the $\mathrm{UO}_{2}-\mathrm{UO}_{3}-\mathrm{Y}_{2} \mathrm{O}_{3}$

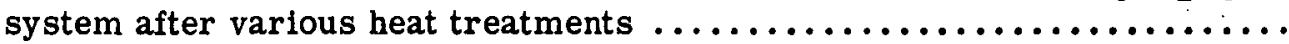

2.2 - Phase relationships and oxygen-to-uranium ratios in the $\mathrm{UO}_{2}-\mathrm{UO}_{3}-\mathrm{Y}_{2} \mathrm{O}_{3}$ system after various heat treatments in a $10 \mathrm{CO}_{2}-1 \mathrm{CO}$ atmosphere at

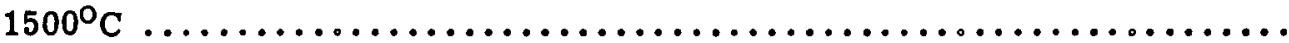

2.3 - Hexagonal unit cell dimensions for the rhombohedral phases ...........

2.4 - Behavior of coprecipitated $\mathrm{UO}_{2}+x^{\cdot} 7 \mathrm{Y}_{2} \mathrm{O}_{3}\left(87.5\right.$ mole $\left.\% \mathrm{Y}_{2} \mathrm{O}_{3}\right)$ solid solution

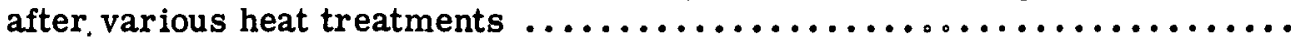

2.5 - Phases present as a function of oxygen-to-uranium ratio for the $\mathrm{UO}_{2+\mathrm{x}} \cdot 3 \mathrm{Y}_{2} \mathrm{O}_{3}$ composition after heating at high temperatures $\ldots \ldots \ldots \ldots$

3.1 - Composition and phases present for $\mathrm{UO}_{2.9} \cdot 3 \mathrm{Y}_{2} \mathrm{O}_{3}$ pellets after high-

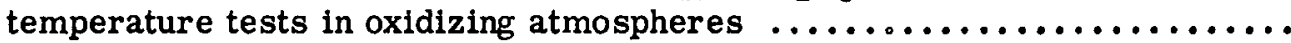

3.2 - X-ray diffraction and chemical analyses of $\mathrm{UO}_{2.99} \cdot 3 \mathrm{Y}_{2} \mathrm{O}_{3}$ powder after

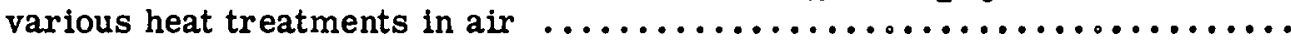

3.3 - Phase change of reduced $\mathrm{UO}_{2}{ }_{2} \cdot 3 \mathrm{Y}_{2} \mathrm{O}_{3}$ thermal expansion specimens

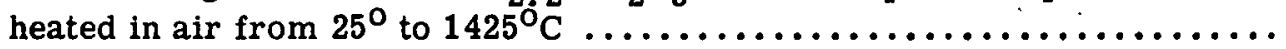

3.4 - X-ray diffraction and chemical analyses of conductivity specimens ....... 45

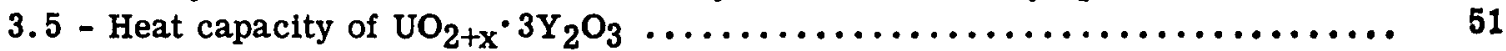

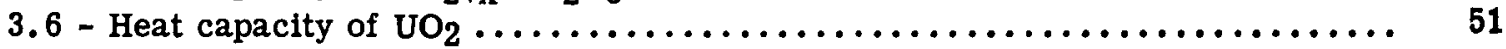

3.7 - Modulus of rupture of oxygen- and hydrogen-sintered $\mathrm{UO}_{2+x} \cdot 3 \mathrm{Y}_{2} \mathrm{O}_{3}$ composition and of oxygen-sintered, reduced, and reoxidized samples ....... 53

3.8 - Modulus of rupture of $\mathrm{UO}_{2.9} \cdot 3 \mathrm{Y}_{2} \mathrm{O}_{3}$ at various temperatures $\ldots \ldots \ldots \ldots \ldots .55$

3.9 - Comparison of calculated stresses in three types of fuel elements for a constant heat removal rate of $150 \mathrm{~g}-\mathrm{cal} / \mathrm{cm}^{2}-\mathrm{sec} \ldots \ldots \ldots \ldots \ldots \ldots$ 

Previous investigations $1,2,3^{*}$ of the $\mathrm{UO}_{2}-\mathrm{UO}_{3}-\mathrm{Y}_{2} \mathrm{O}_{3}$ system revealed the presence of four phases: (1) $\mathrm{U}_{3} \mathrm{O}_{8}$, (2) a mixed oxide phase having the fluorite structure, (3) a phase having rhombohedral symmetry, and (4) a phase of the body-centered $\mathrm{Y}_{2} \mathrm{O}_{3}$ structure. In recent years, a number of studies ${ }^{4-11}$ have been carried out on the solid solutions of the trivalent rare earth oxides $\mathrm{La}_{2} \mathrm{O}_{3}, \mathrm{Ce}_{2} \mathrm{O}_{3}, \mathrm{Pr}_{2} \mathrm{O}_{3}, \mathrm{Nd}_{2} \mathrm{O}_{3}$, and $\mathrm{Sm}_{2} \mathrm{O}_{3}$ with the tetravalent oxides $\mathrm{ZrO}_{2}, \mathrm{CeO}_{2}$, and $\mathrm{PrO}_{2}$. In each of the systems, a homogenous region having the fluorite structure was found to exist from 0 to about 45 mole percent $\mathrm{R}_{2} \mathrm{O}_{3}$. Oxygen deficiency leads to random vacancies in the anion lattice as shown by $X$-ray line intensities and by correlation of density measurements with theoretical densities for anion vacancy and cation interstitial models.

In some of the systems, when the flourite lattice becomes sufficiently anion deficient, the lattice transforms to rhombohedral symmetry. Baenziger et al12,13 reported two different rhombohedral oxide structures for praseodymium ( $\mathrm{PrO}_{1.71}$ and $\mathrm{PrO}_{1.85}$ ) and similarly for terbium oxide. The $\mathrm{MO}_{1.71}$ rhombohedral structure also was identified in the $\mathrm{UO}_{2}-\mathrm{UO}_{3}$ $\mathrm{Y}_{2} \mathrm{O}_{3}$ system in air at the composition $\mathrm{UO}_{3} \cdot 3 \mathrm{Y}_{2} \mathrm{O}_{3}$. Unpublished work by one of the authors of this report (Juenke) also established the existence of the rhombohedral phase solid solutions of urania with oxides of $\mathrm{La}$ and the rare earths $\mathrm{Pr}, \mathrm{Nd}, \mathrm{Sm}, \mathrm{Eu}, \mathrm{Gd}, \mathrm{Tb}, \mathrm{Dy}, \mathrm{Ho}, \mathrm{Er}$, $\mathrm{Tm}, \mathrm{Yb}$, and $\mathrm{Lu}$.

Studies by Hund and Peetz 5 and by Hund, Peetz, and Kottenbahn ${ }^{1}$ showed that fluorite phases occur in solid solutions prepared at $1200^{\circ} \mathrm{C}$ in air by the reaction of $\mathrm{U}_{3} \mathrm{O}_{8}$ with various Group III oxides, including $\mathrm{Y}_{2} \mathrm{O}_{3}, \mathrm{La}_{2} \mathrm{O}_{3}$, and many of the other rare earth sesquioxides crystallizing with the "C-type" structure. For $\mathrm{Y}_{2} \mathrm{O}_{3}$, the fluorite phase extended from 18 to 48 mole percent $\mathrm{Y}_{2} \mathrm{O}_{3}$. Below 18 mole percent $\mathrm{Y}_{2} \mathrm{O}_{3}$, a two-phase.region was reported which consisted of $\mathrm{U}_{3} \mathrm{O}_{8}$ as one phase and the fluorite-boundary mixed crystal as the other. At about 38 mole percent $\mathrm{Y}_{2} \mathrm{O}_{3}$, the cation and anion sites became fully occupled, and at higher concentrations of $\mathrm{Y}_{2} \mathrm{O}_{3}$, anion vacancies were present. Near 48 mole percent $\mathrm{Y}_{2} \mathrm{O}_{3}$, the authors reported the inability to attain complete conversion after heating at $1200^{\circ} \mathrm{C}$ for 8 hours in air.

Anderson, Ferguson, and Roberts, ${ }^{8}$ and Ferguson and $\mathrm{Fogg}^{9}$ reacted $\mathrm{UO}_{2}$ and $\mathrm{Y}_{2} \mathrm{O}_{3}$ in vacuum at $2000^{\circ} \mathrm{C}$ to form fluorite solid solutions. $X$-ray and chemical analysis together with color changes indicated that these solld solutions had a strong affinity for oxygen, oxidizing rapidly in air at room temperature. Reacting $\mathrm{UO}_{2}$ and $\mathrm{Y}_{2} \mathrm{O}_{3}$ in evacuated and sealed quartz capsules containing clean uranium metal at $10000 \mathrm{C}$ for 1 to 3 days produced a highly reduced solid solution. Under these conditions, a fluorite soltd solution was obtained from 0 to 48 mole percent $\mathrm{Y}_{2} \mathrm{O}_{3}$. Between 48 and 64 mole percent $\mathrm{Y}_{2} \mathrm{O}_{3}$, the measured fluorite cell constants behaved irregularly. Between 64 and 93 mole percent, a miscibllity gap was observed. Beyond 93 mole percent, a body-centered cubic solld solution was observed.

Previous results on the behavior of mixed oxides prepared under both reducing and oxidizing conditions are somewhat incomplete in the $\mathrm{Y}_{2} \mathrm{O}_{3}-$ rich region. This report attempts

*Superscripts refer to the references listed in Section 5 . 
to clarify some of the phase relationships in this region under various oxidizing and reducing conditions. A tentative phase diagram was constructed from the data obtained.

\subsection{EXPERIMENTAL WORK}

Urania-yttria solid solutions were prepared by blending Mallinckrodt grade $\mathrm{UO}_{2}$ (purity 99.99 percent) and $\mathrm{Y}_{2} \mathrm{O}_{3}$ (purity 99.9 percent) powders. The homogenous mixture was fired in air in platinum or zirconia crucibles at $1480^{\circ} \mathrm{C}$ for 60 hours. The powders were then reduced in a hydrogen atmosphere at various temperatures and times. Some compositions were reacted directly in hydrogen without pre-reacting in air and showed no difference in the X-ray diffraction pattern. The X-ray and chemical analyses were performed after each treatment and are summarized in Table 2.1. One composition ( 60 mole percent $\mathrm{Y}_{2} \mathrm{O}_{3}$ ) was pre-reacted at $1850^{\circ} \mathrm{C}$ in air for 2 hours before reduction in hydrogen to overcome the apparently slow reaction rate characteristic of this composition. Compositions which were urania-rich showed a tendency to oxidize spontaneously in air at room temperature and were handled under an argon blanket to prevent oxidation.

The hydrogen-reduced compositions were re-oxidized in air at low temperatures $\left(<540^{\circ} \mathrm{C}\right)$ and at high temperatures $\left(>1300^{\circ} \mathrm{C}\right)$. These results are summarized in Table 2.1. The amounts of each phase present were determined quantitatively by comparing the relative contribution of the most prominent X-ray peak intensities for each phase. The phase boundaries in two-phase regions were then determined by application of the "lever" rule. The oxygen-to-uranium ratio was determined by chemical analysis for $\mathrm{U}^{+4}$ and total uranium, and the $U^{+6}$ content was determined by difference. An inter mediate level in the oxidation state was obtained by heating powders in a 10:1 $\mathrm{CO}_{2}$ - $\mathrm{CO}$ atmosphere. As shown in Table 2.2, both oxidized and reduced solid solutions were used as starting materials to determine if equilibrium could be established. A heat treatment of 20 hours at $1500^{\circ} \mathrm{C}$ was considered sufficient to reach equilibrium; however, the rate of approach to equilibrium from the oxidized direction appeared to be slower, particularly at the 60 mole percent $\mathrm{Y}_{2} \mathrm{O}_{3}$ composition.

For reacted compositions heated in hydrogen at $1700^{\circ} \mathrm{C}$, the structures were believed to be essentially at equilibrium, although this was not determined in all cases. The degree of reduction increased with higher heating temperatures or lower oxygen partial pressures. During oxidation below $500^{\circ} \mathrm{C}$, the oxygen-to-uranium ratio comes to equilibrium in a few hours with respect to whatever lattice structure is present as a result of reduction at high temperatures; during oxidation at high temperatures, it equillbrated rapidly relative to the sluggish structure changes which require cation mobility as well as anion mobility.

\subsection{PHASE DIAGRAM}

The ternary phase diagram is shown for two temperature regions, between $1000^{\circ}$ and $1700^{\circ} \mathrm{C}$ and below $1000^{\circ} \mathrm{C}$. The higher temperature diagram shown in Figure 2.1 represents essentially an equillbrium system where the solld lines represent established phase boundarles and the dashed lines represent probable boundaries which are not well established. The lighter dashed lines describe the approximate composition line for three conditions: (1) hydrogen, $-40^{\circ} \mathrm{C}$ dewpoint, $1700^{\circ} \mathrm{C}$; (2) air, $1000^{\circ} \mathrm{C}$; and (3) $10 \mathrm{CO}_{2}-1 \mathrm{Co}$ at $1500^{\circ} \mathrm{C}$. The symbols designate the phases observed at the various compositions. Twophase regions are indicated by overlapping symbols.

The region along the $\mathrm{UO}_{2}-\mathrm{UO}_{3}$ join was not studied in this work; this portion of the diagram was constructed from the work of others. ${ }^{14}$ The extent of the solubility of $\mathrm{Y}_{2} \mathrm{O}_{3}$ in the $\mathrm{U}_{4} \mathrm{O}_{9}$ phase or in the $\mathrm{U}_{3} \mathrm{O}_{8}$ phase was not determined. The $\mathrm{UO}_{3}$ corner was not constructed because its stable range occurs at pressures which are outside the range of interest. The region along the $\mathrm{UO}_{2}-\mathrm{Y}_{2} \mathrm{O}_{3}$ join was drawn from the results of the work done

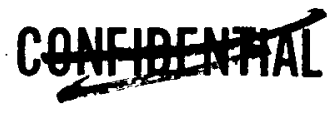


TABLE 2.1

PHASE RELATIONSHIPS AND OXYGEN-TO-URANIUM RATIOS
IN THE UO ${ }_{2}-\mathrm{UO}_{3}-\mathrm{Y}_{2} \mathrm{O}_{3}$ SYSTEM AFTER VARIOUS HEAT TREATMENTS

\begin{tabular}{|c|c|c|c|c|c|c|c|c|c|c|c|c|c|c|c|c|c|}
\hline \multicolumn{2}{|c|}{ Composition } & \multicolumn{4}{|c|}{ Hydrogen Reaction ${ }^{2}$} & \multicolumn{4}{|c|}{ Low-Temperature Oxidation } & \multicolumn{4}{|c|}{ High-Temperature Oxidation } & \multicolumn{4}{|c|}{ Air Reaction } \\
\hline $\begin{array}{l}\mathrm{UO}_{2} \\
\text { Mole \% }\end{array}$ & 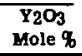 & $\begin{array}{c}\begin{array}{c}\text { Temperature, } \\
{ }^{\circ} \mathrm{C}\end{array} \\
\end{array}$ & $\begin{array}{c}\text { Time, } \\
\mathrm{hr}\end{array}$ & Phases & $o / u^{b}$ & $\begin{array}{c}\text { Temperature, } \\
{ }^{\circ} \mathrm{C}\end{array}$ & $\begin{array}{c}\text { Time, } \\
\mathrm{hr}\end{array}$ & Phases & $\mathrm{O} / \mathrm{U}^{\mathrm{b}}$ & $\begin{array}{c}\text { Temperature, } \\
{ }^{\circ} \mathrm{C}\end{array}$ & $\begin{array}{l}\text { Time, } \\
\text { hr }\end{array}$ & phases & $\mathrm{o} / \mathrm{U}^{\mathrm{b}}$ & $\begin{array}{l}\text { Temperabure, } \\
{ }_{0}^{\circ} \mathrm{C}\end{array}$ & $\begin{array}{c}\text { Time, } \\
\mathrm{hr}\end{array}$ & Phases & $\mathrm{o} / \mathrm{u}^{\mathrm{b}}$ \\
\hline 12.5 & 87.5 & $1650^{c}$ & 3 & BCC & 203 & 540 & 2 & BCC & 2.8 & & & & & & & & \\
\hline & & $\begin{array}{l}1700 \\
1700^{d}\end{array}$ & $\begin{array}{l}12 \\
18\end{array}$ & $\begin{array}{c}\text { BCC } \\
93 \% \text { BCC }-7 \% \text { Rh I }\end{array}$ & $\begin{array}{l}2.28 \\
2.24\end{array}$ & 540 & 65 & $\mathrm{BCC}$ & & $\begin{array}{l}1315 \\
1400\end{array}$ & $\begin{array}{l}45 \\
16\end{array}$ & $\begin{array}{l}50 \% \text { BCC }-50 \% \text { Rh I } \\
55 \% \text { BCC }-45 \% \text { Rh I }\end{array}$ & 2. 99 & & & & \\
\hline 14. 3 & 85.7 & $1700^{d}$ & 18 & $90 \%$ BCC - $10 \%$ Rh I & 2. 23 & & & & & 1400 & 16 & $45 \%$ BCC $-55 \%$ Rh I & 2. 99 & & & & \\
\hline 16.7 & 89.3 & $\begin{array}{l}1650^{c} \\
1700^{d}\end{array}$ & $\begin{array}{r}3 \\
18\end{array}$ & $\begin{array}{l}\text { BCC - Trace PCC } \\
\text { BO BCC - 12\% Rh I }\end{array}$ & $\begin{array}{l}2.04 \\
\text { 2. } 25\end{array}$ & 540 & 2 & BCC - Trace FCC & & 1400 & 16 & $30 \% \mathrm{BCC}-70 \% \mathrm{Rh} \mathrm{I}$ & 2. 99 & & & & \\
\hline 20.0 & 80.0 & $1700^{d}$ & 18 & $83 \%$ BCC - $17 \%$ Rh I & 2.27 & & & & & 1400 & 16 & $22 \% \mathrm{BCC}-7 \% \% \mathrm{Rh} \mathrm{I}$ & 2. 99 & & & & \\
\hline 22.2 & 77. 8 & 1700 & 12 & $72 \%$ BCC $-28 \% \mathrm{Rh} \mathrm{I}$ & 2.25 & 288 & 71 & $72 \%$ BCC $-20 \%$ Rh II & & & & & & & & & \\
\hline 25.0 & 75.0 & $\begin{array}{l}1650 c \\
1700 d\end{array}$ & $\begin{array}{r}3 \\
18\end{array}$ & $\begin{array}{l}70 \% \text { BCC }-30 \% \text { FCC } \\
70 \% \text { BCC - 30\% Fh I }\end{array}$ & $\begin{array}{l}2.10 \\
2.20\end{array}$ & 540 & 2 & $70 \% \mathrm{BCC}-30 \%$ FCC & 2.8 & 1400 & 16 & $10 \%$ BCC $-90 \%$ Rh I & 2.97 & $\begin{array}{l}1850 \\
1370\end{array}$ & $\begin{array}{r}2 \\
16\end{array}$ & $\begin{array}{l}100 \% \mathrm{Rh} \mathrm{I} \\
100 \% \mathrm{Rh} \mathrm{I}\end{array}$ & 2. 99 \\
\hline & & 1700 & 30 & $72 \%$ BCC $-28 \%$ Rh I & 2. 28 & 540 & 20 & 72\% BCC - 28\% Rh II & & 1315 & 5 & $100 \%$ Rh I & & & & & \\
\hline 30.8 & 69.2 & $\begin{array}{l}1650 C \\
1700\end{array}$ & $\begin{array}{r}9 \\
66\end{array}$ & $\begin{array}{l}60 \% \text { BCC }-10 \% \text { FCC } \\
60 \% \text { BCC }-10 \% \text { Ph } 1\end{array}$ & $\begin{array}{l}2.06 \\
2.27\end{array}$ & $\begin{array}{l}540 \\
288\end{array}$ & $\begin{array}{r}2 \\
71\end{array}$ & $\begin{array}{l}60 \% \mathrm{BCC}-40 \% \mathrm{FCC} \\
60 \% \mathrm{BCC}-40 \% \text { Rh II }\end{array}$ & $\begin{array}{l}2.9 \\
2.71\end{array}$ & 1480 & 100 & $60 \%$ Rh $1-40 \%$ FCC & & 1970 & 25 & $80 \%$ Rh I- $20 \%$ FCC & \\
\hline 33.3 & 66.7 & 1700 & 66 & $44 \%$ BCC - 5\% Rh I & 2. 28 & 288 & 71 & $44 \%$ BCC $-56 \%$ Rh I & 2.79 & 1650 & 16 & $50 \%$ Rh I $-50 \%$ FCC & & 1370 & 25 & $60 \% \mathrm{Rh} 1-40 \% \mathrm{FCC}$ & \\
\hline 40.0 & 60.0 & $\begin{array}{l}1540 \\
1700\end{array}$ & $\begin{array}{r}3 \\
12\end{array}$ & $\begin{array}{c}\text { Rh I } \\
200 \% \text { BCC - } 800 \% \text { Rh I }\end{array}$ & $\begin{array}{l}23 \\
22\end{array}$ & $\begin{array}{l}260 \\
540\end{array}$ & $\begin{array}{l}52 \\
25\end{array}$ & $\begin{array}{c}\mathrm{Rh} \mathrm{I} \\
20 \% \mathrm{BCC}-\mathrm{BOO} \text { Rh II }\end{array}$ & & $\begin{array}{l}1315 \\
1850 \\
1460\end{array}$ & $\begin{array}{r}4 \\
5 \\
16\end{array}$ & $\begin{array}{c}\text { Trace Rh I- FCC } \\
100 \% \text { FCC } \\
\text { Trace Rh 1-FCC }\end{array}$ & & 1850 & 2 & $100 \%$ FCC & \\
\hline 45.5 & 54.5 & 1700 & 12 & $15 \%$ BCC -855 Rh 1 & 2.25 & 288 & 71 & $15 \%$ BCC - 85\% Rh II & & & & & & & & & \\
\hline 50.0 & 50.0 & 1700 & 66 & SOO Rh I - 700 FCC & $2.58^{e}$ & 288 & 71 & $30 \%$ Rh II $-70 \%$ FCC & 2.88 & & & & & 1370 & 25 & $100 \% \mathrm{FCC}$ & 2. 88 \\
\hline 60.0 & 40.0 & 1700 & 66 & $100 \%$ FCC & $2.63^{\mathrm{e}}$ & 288 & 71 & $1008 \mathrm{FCC}$ & 2. 67 & & & & & 1370 & 25 & $100 \mathrm{FCC}$ & 2. 68 \\
\hline 66.7 & 33.3 & 1700 & 12 & 1008 FCC & $-e$ & 288 & 65 & $100 \%$ FCC & 2. 52 & & & & & 1300 & 16 & $100 \%$ FCC & 2.52 \\
\hline 71.5 & 28.5 & 1700 & 12 & $1008 \mathrm{FCC}$ & e & 288 & 65 & $100 \%$ FCC & 2.44 & & & & & 1300 & 16 & $90 \%$ FCC $-10 \% \mathrm{U}_{3} \mathrm{O}_{8}$ & 2.53 \\
\hline 77. $\mathrm{c}$ & 23.0 & 1700 & 12 & $100 \$$ FCC & $-\mathbf{e}$ & 288 & 65 & $100 \%$ FCC & 2. 36 & & & & & 1300 & 16 & $708 \mathrm{FCC}-308 \mathrm{U} \mathrm{U}_{3} \mathrm{O}_{8}$ & 2.56 \\
\hline 82.5 & 17.5 & 1700 & 12 & $100 \%$ FCC & $-\mathbf{e}$ & 288 & 65 & $100 \%$ FCC & 2. 26 & & & & & 1300 & 16 & $50 \%$ FCC $-50 \% \mathrm{U}_{3} \mathrm{O}_{8}$ & 2.59 \\
\hline 88.3 & 11.7 & 1700 & 12 & $1008 \mathrm{FCC}$ & -e & 288 & 65 & $100 \%$ FCC & 2.18 & & & & & 1300 & 16 & $36 \% \mathrm{FCC}-64 \% \mathrm{U}_{3} \mathrm{O}_{8}$ & 2.62 \\
\hline 95 & 5 & 1700 & 40 & $\begin{array}{l}\text { PCC }+ \\
\text { Trace } \mathrm{DO}_{2+2}\end{array}$ & 2.05 & 288 & 24 & $\begin{array}{l}\text { FCC } \\
\text { FCC } \\
\text { Trace Tetrag. } U_{3} \mathrm{O}_{7}\end{array}$ & & $800^{\circ} \mathrm{C}$ & 24 & $\begin{array}{l}\mathrm{U}_{3} \mathrm{O}_{8} \\
\text { Trace ECC }\end{array}$ & & & & & \\
\hline 98 & 2 & 1700 & 60 & $\begin{array}{l}708 \mathrm{FCC}+ \\
30 \% \mathrm{DO}_{2+\mathrm{x}}\end{array}$ & 2.04 & 288 & 24 & $\begin{array}{l}70 \% \text { FCC }+ \\
30 \% \text { Tetrag. } \mathrm{U}_{3} \mathrm{O}_{7}\end{array}$ & & $800^{\circ} \mathrm{C}$ & 24 & $\begin{array}{l}\mathrm{U}_{3} \mathrm{O}_{8} \\
\text { Trace FCC }\end{array}$ & & & & & \\
\hline
\end{tabular}

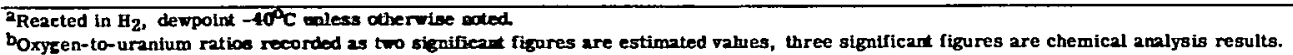

bOxysen-to-uranium ratios recorded as two significast figars

$d_{\text {Rea }}$ ted in $\mathrm{H}_{2}$, dewpoint $0^{\circ} \mathrm{C}$

espontaneously oxidized upon exposare to sir. 
TABLE 2.2

PHASE RELATIONSHIPS AND OXYGEN-TO-URANIUM RATIOS IN THE UO ${ }_{2}$-UO $\mathrm{O}_{3}-\mathrm{Y}_{2} \mathrm{O}_{3}$ SYSTEM

AFTER VARIOUS HEAT TREATMENTS NN A $10 \mathrm{CO}_{2}-1 \mathrm{CO}$ ATMOSPHERE AT $1500^{\circ} \mathrm{C}$

\begin{tabular}{|c|c|c|c|c|c|c|c|c|c|c|}
\hline \multirow{2}{*}{$\begin{array}{l}\text { Composition } \\
\text { State of Materials }\end{array}$} & \multicolumn{2}{|c|}{$49 \mathrm{UO}_{2}: \mathrm{NY}_{2} \mathrm{O}_{3}$} & \multicolumn{2}{|c|}{$19 \mathrm{UO}_{2}: 1 \mathrm{Y}_{2} \mathrm{O}_{3}$} & \multicolumn{2}{|c|}{$7.5 \mathrm{UO}_{2}: 1 \mathrm{Y}_{2} \mathrm{O}_{3}$} & \multicolumn{2}{|c|}{ 2. $5 \mathrm{UO}_{2}: 1 \mathrm{Y}_{2} \mathrm{O}_{3}$} & \multicolumn{2}{|c|}{$2 \mathrm{UO}_{2}: 1 \mathrm{YY}_{2} \mathrm{O}_{3}$} \\
\hline & Reduced & Oxidized & Reduced & Oxldized & Reduced & Oxddized & Reduced & Oxidlzed & Reduced & Oxddzed \\
\hline $\begin{array}{l}\text { O/U Ratio and Phases - } \\
\text { Starting Materials }{ }^{\mathrm{b}}\end{array}$ & $\begin{array}{l}2.04-70 \% \text { FCC } \\
30 \% \cup_{2+x}\end{array}$ & - & $2.05-\begin{array}{l}\text { FCC } \\
\text { Trace } \mathrm{UO}_{2+\mathrm{X}}\end{array}$ & - & - $F C C^{d}$ & - & $-\quad F C C^{d}$ & - & $-\operatorname{FCCd}$ & - \\
\hline $\begin{array}{l}\text { O/O Ratio and Phases } \\
\text { After Time at } 1500^{\circ} \mathrm{C} \text { (5 bur) }\end{array}$ & - & - & 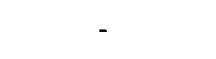 & - & - & - & - & $\cdot$ & - & - \\
\hline $\begin{array}{l}(10 \mathrm{hr}) \\
(24 \mathrm{hr})\end{array}$ & 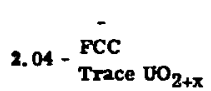 & - & $\begin{array}{l}-\overline{\mathrm{FCC}} \\
2.08- \\
\text { Trace } \mathrm{UO}_{2+\mathrm{X}}\end{array}$ & - & 2.22- FCC & - & 2. $38-$ FCC & - & $2.44-\overline{F C C}$ & $\begin{array}{l}- \\
-\end{array}$ \\
\hline
\end{tabular}

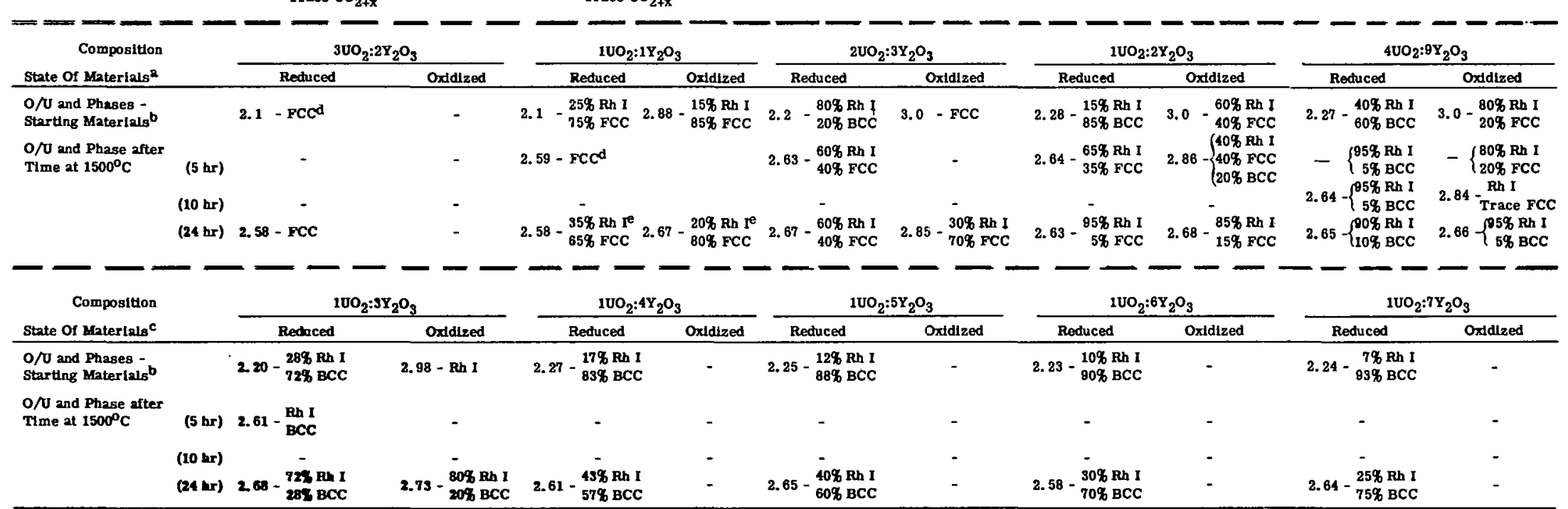

2Reduced: Reacted 12 io 70 hours it $1700^{\circ} \mathrm{C}$ in $\mathrm{B}_{2}$. Oxidired: Reacted 12 to 24 hours at $1500^{\circ}$ to $1400^{\circ} \mathrm{C}$ in Air.

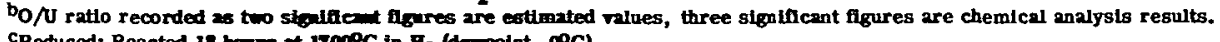

CReduced: Reacted 18 worrs at $1700{ }^{\circ} \mathrm{C}$ in $\mathrm{B}_{2}$ (derpolat, $0^{\circ} \mathrm{C}$ ).

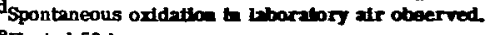

Eleated 50 hours. 


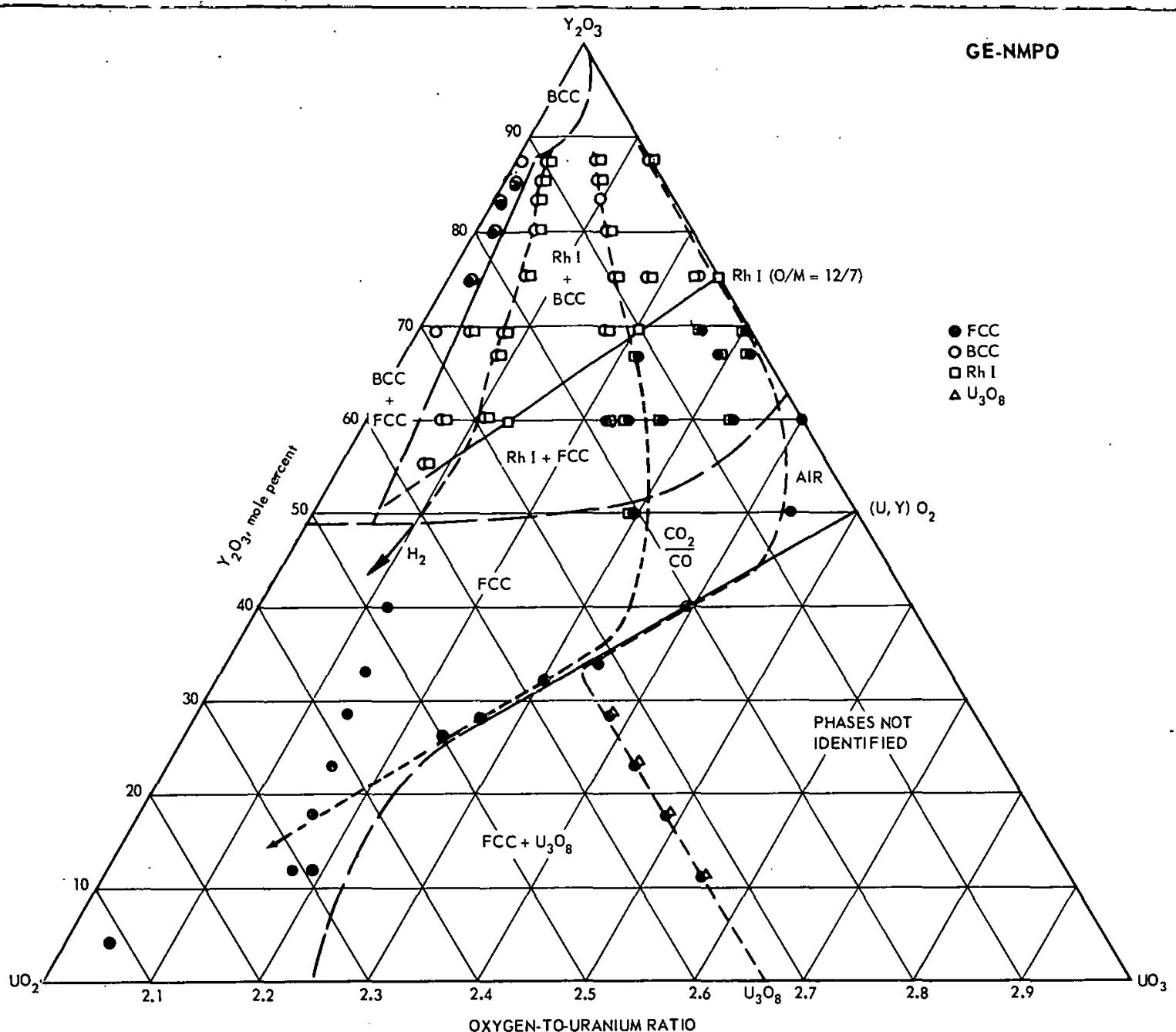

Fig. $2.1-$ The $\mathrm{UO}_{2}-\mathrm{UO}_{3}-\mathrm{Y}_{2} \mathrm{O}_{3}$ ternary diagram from $1000^{\circ}$ to $1700^{\circ} \mathrm{C}$

in vacuum at $2000^{\circ} \mathrm{C}$ by Anderson, et al. ${ }^{8}$ The $\mathrm{Y}_{2} \mathrm{O}_{3}$ corner is somewhat complex and is not completely understood. It appears that urania solubility in the body-centered cublc (BCC) phase decreases from about 14 mole percent $\mathrm{UO}_{2}$ to approximately 0 mole percent $\mathrm{UO}_{3}$.

The low-temperature diagram, Figure 2.2, shows the phases present before and after oxidation at the indicated temperature. Some of these structures are metastable and transform to the equilibrium structure when heated above $1000^{\circ} \mathrm{C}$. In this temperature region, a second rhombohedral phase (Rh II) was observed between 50 and 60 mole percent $\mathrm{Y}_{2} \mathrm{O}_{3}$ in air. This phase transformed to a face-centered cubic (FCC) phase at temperatures above $1000^{\circ} \mathrm{C}$. The crystalline phases present in the system are discussed below.

\section{Face-Centered Cubic Fluorite Phase}

Solid solutions of $\mathrm{UO}_{2+x}$ with $\mathrm{Y}_{2} \mathrm{O}_{3}$ that have a $\mathrm{FCC}$ structure are well established. The primary interest in this work was determining the single-phase region and changes in unit cell size with composition and oxidation state. The fluorite structure extends from about 0 to 45 mole percent $\mathrm{Y}_{2} \mathrm{O}_{3}$ under strongly reducing conditions. These materials oxidize rapidly in air at room temperature, and oxygen readily diffuses into vacant anion sites. This results.in a shrinkage of the unit cell which was observed by $\mathrm{X}$-ray diffractometry 


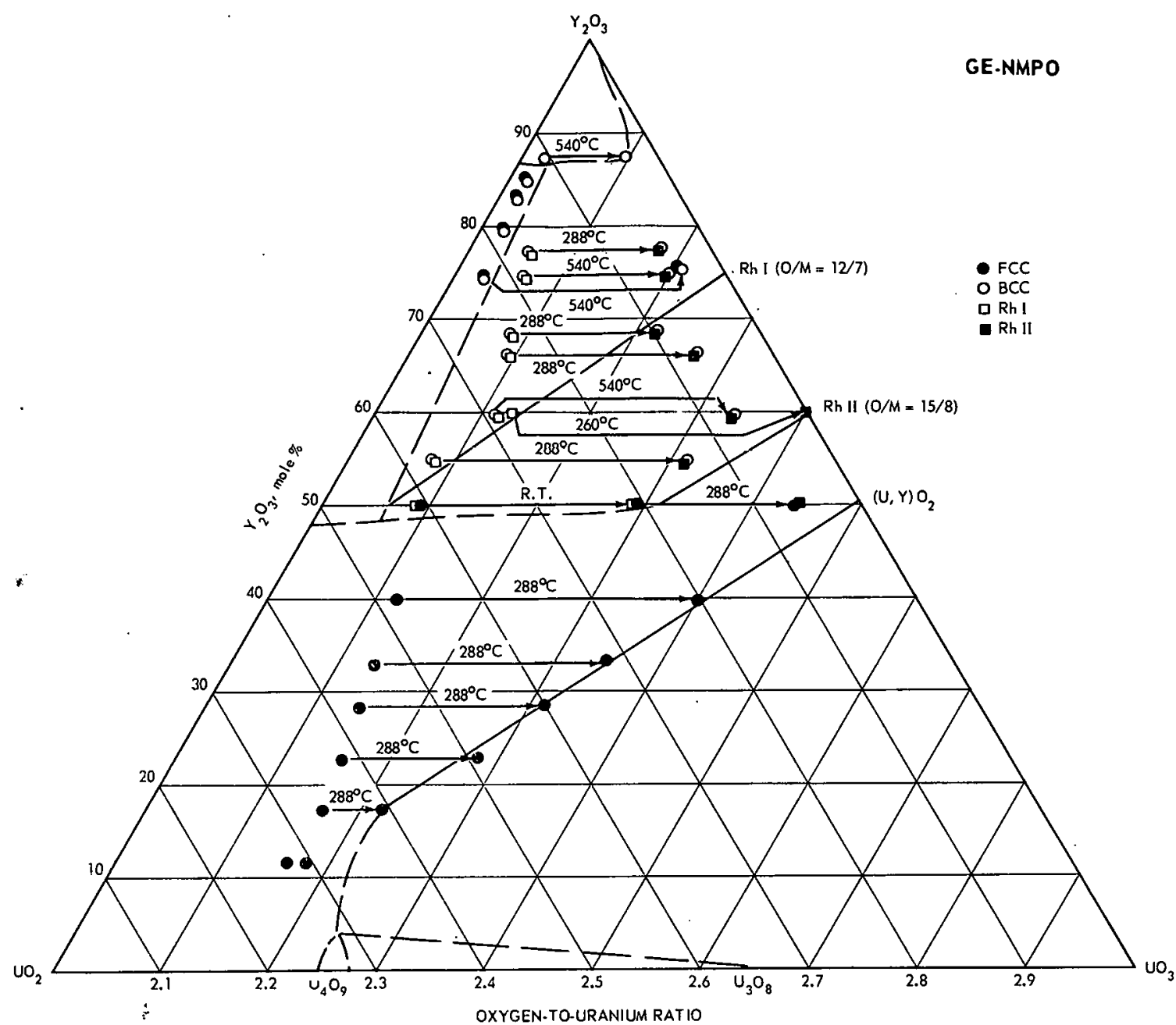

Fig. 2.2 - The $\mathrm{UO}_{2}-\mathrm{UO}_{3}-\mathrm{Y}_{2} \mathrm{O}_{3}$ system (low-tcmpcrature oxidation below $1000^{\circ} \mathrm{C}$ )

(see Figure 2.3). The composition $1 \mathrm{UO}_{2} \cdot 1 \mathrm{Y}_{2} \mathrm{O}_{3}$ is the most sensitive since it contains the largest number of vacancies. Chemical analysis indicates an oxygen-to-uranium ratio of about 2.67 after spontaneous oxidation of this composition.

As the oxygen-to-uranium ratio is increased, the fluorite-phase region becomes narrower. The fluorite boundary on the oxygen-deficient side occurs in the vicinity of 50 mole percent $\mathrm{Y}_{2} \mathrm{O}_{3}$ and may be varlable depending on the temperature. At 50 mole percent $\mathrm{Y}_{2} \mathrm{O}_{3}$, both a single-phase FCC and two-phase FCC and Rh I mixture were obtained, hence the exact location of the boundary is not known.

There is no indication, within the accuracy of measurement, that excess oxygen atoms occupy interstitial positions in the lattice at high temperatures $\left(>1000^{\circ} \mathrm{C}\right)$ in air when the yttria content is above 20 mole percent. Results of thermodynamic measurements by Aronson and Belle ${ }^{15}$ Indicate that an oxygen-excess solid solution of $\mathrm{MO}_{2} .03$ composition could be made at 15 mole percent $\mathrm{Y}_{2} \mathrm{O}_{3}:$. At low temperatures, the amount of inter stitial oxygen appears to be increasing as the yttria content is decreased and approaches the limiting value near $\mathrm{MO}_{2.25}$ at 0 percent $\mathrm{Y}_{2} \mathrm{O}_{3}$. As the $\mathrm{Y}_{2} \mathrm{O}_{3}$ concentration is decreased, the lattice expansion probably permits increasing amounts of interstitial oxygen.

At low yttria concentrations (2 to 5 mole $\% \mathrm{Y}_{2} \mathrm{O}_{3}$ ), both $\mathrm{UO}_{2+\mathrm{x}}$ and $(\mathrm{U}, \mathrm{Y}) \mathrm{O}_{2.0}$ phases were present after heating repeatedly in $\mathrm{CO}_{2}-\mathrm{CO}$ or in hydrogen atmospheres. In lieu of dissolving 


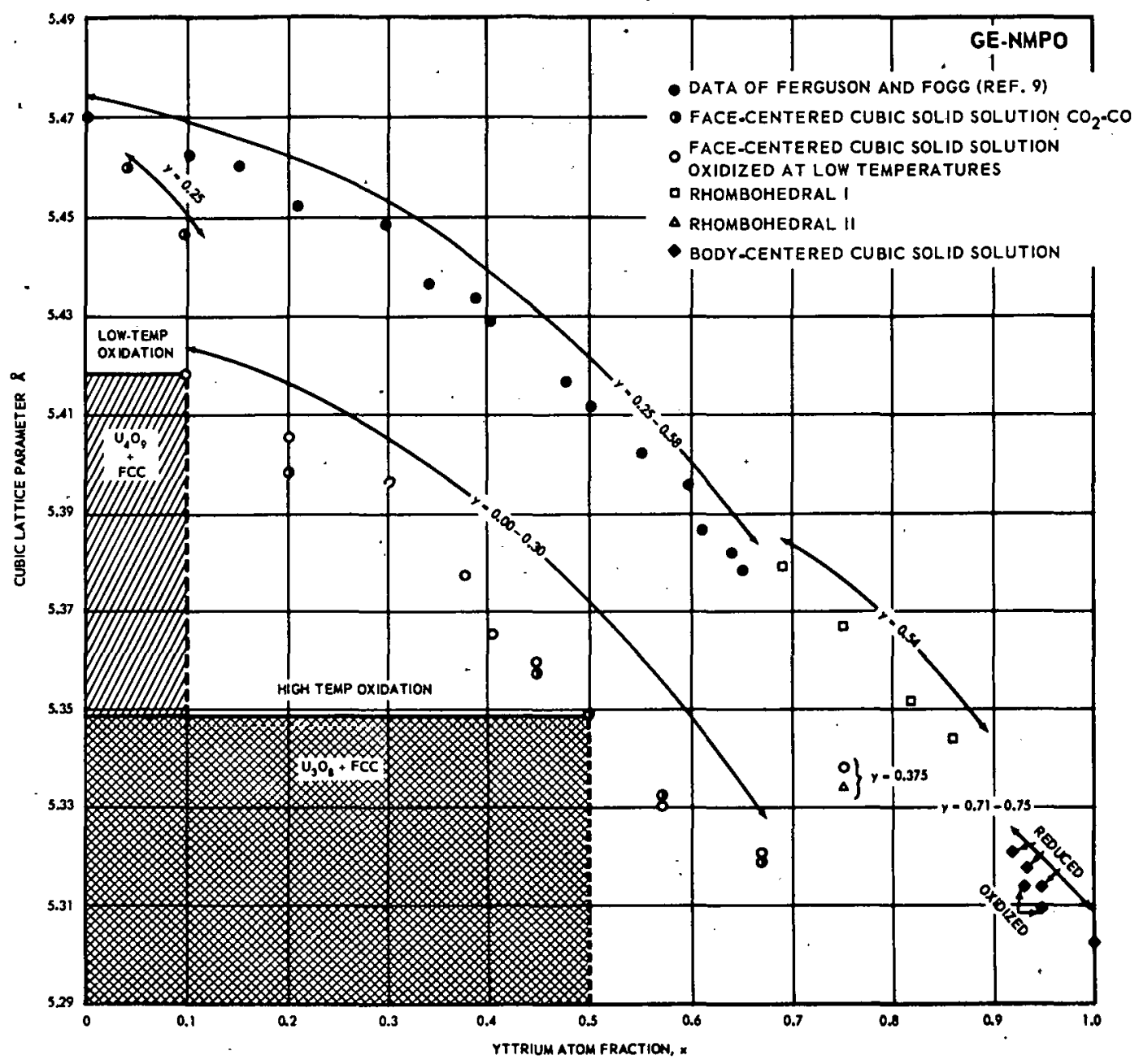

Fig. 2.3.- Comparison of equivalent cubic lattice parameter of $\left(U_{1-x}, Y_{x}\right) O_{2.25-y}$ composition as a function of cation fraction of yttrium

Interstitial oxygen, the urania-yttria solid solution may reject a small amount of $\mathrm{UO}_{2+\mathrm{x}} \mathrm{so}$ that the solid solution remains at the stolchiometric composition, $\mathrm{MO}_{2}$. One experiment carried out in $\mathrm{Ar}-1$ volume percent $\mathrm{O}_{2}$ at $1500^{\circ} \mathrm{C}$ to determine if three phases, $\mathrm{UO}_{2+\mathrm{x}}$, $(\mathrm{U}, \mathrm{Y}) \mathrm{O}_{2}$, and $\mathrm{U}_{3} \mathrm{O}_{8}$, could be formed resulted in only a $\mathrm{U}_{3} \mathrm{O}_{8}$ and a $(\mathrm{U}, \mathrm{Y}) \mathrm{O}_{2}$ phase. The fluorite boundary on the oxygen-excess side near the $\mathrm{UO}_{2}$ corner 18 tentatively drawn as a curved line which departs from the stolchiometric $(\mathrm{U}, \mathrm{Y}) \mathrm{O}_{2}$ line and intersects the $\mathrm{UO}_{2}$ $\mathrm{UO}_{3}$ boundary at $\mathrm{UO}_{2.25}$.

The change in lattice parameter for the fluorite cell as a function of yttrium atom fraction is shown in Figure 2.3. The data of Ferguson and Fogg ${ }^{9}$ are Included to indicate the variation in lattice parameter at a constant oxygen-to-uranium ratio of about 2.0. The fluorite lattice parameters after high-temperature treatment in $\mathrm{CO}_{2}$ - $\mathrm{CO}$ atmosphere represent a composition of constant oxygen-to-metal ratio $(y=0.25)$. The lattice parameters after low-temperature oxidation are also for compositions at oxygen-to-metal ratios of 2. 0 at high yttria content, but as the yttria content is decreased the compositions absorb excess oxygen and the lattice parameter approaches the lattice constant for $\mathrm{UO}_{2} .25$. Rhombohedral Phases (Rh I and Rh II)

The existence of a rhombohedral phase at an oxygen-to-metal atom ratio of 12:7 was reported previously. ${ }^{3}$ This structure (Rh I) can occur over the composition range from about 
$17 \mathrm{UO}_{2} .17 \cdot 18 \mathrm{Y}_{2} \mathrm{O}_{3}$ to $1 \mathrm{UO}_{3.0} \cdot 3 \mathrm{Y}_{2} \mathrm{O}_{3}$. At low-oxidation levels, there is probably a random distribution of metal ions in the oxygen matrix, while in the fully oxldized state a highly ordered arrangement is indicated.

A closely related rhombohedral phase ( $R \mathrm{~h}$ II) was found to exist at a constant oxygen-tometal atom ratio of $15: 8$, with a composition range from $17 \mathrm{UO}_{2.67} \cdot 18 \mathrm{Y}_{2} \mathrm{O}_{3}$ to $2 \mathrm{UO}_{3} \cdot 3 \mathrm{Y}_{2} \mathrm{O}_{3}$. This is probably a metastable phase since it was observed only as a low-temperature intermediate compound during the oxidation of $\mathrm{Rh} \mathrm{I}$. This transformation from the $\mathrm{Rh} I$ to $\mathrm{Rh}$ II structure can be explained by a partial filling of oxygen sites. This mechanism is evidenced in the change in X-ray diffraction patterns; the extra lines attributed to the rhombohedral structure decrease markedly in intensity after oxidation.

Hexagonal unit cell dimensions and volume of the rhombohedral phases are compared in Table 2.3. Decreasing cell size is caused by both a compositional change as well as the substitution of $U^{+6}$ for $U^{+4}$ ions.

TABLE 2.3

HEXAGONAL UNIT CELL DIMENSIONS FOR THE RHOMBOHEDRAL PHASES

\begin{tabular}{|c|c|c|c|}
\hline $\begin{array}{l}\mathrm{Rh} \text { I Composition } \\
\text { (Oxygen-To-Metal } \\
\quad=1.714)\end{array}$ & $\begin{array}{r}\text { Lattice } \\
\text { Constants, }\end{array}$ & $\begin{array}{l}\text { Rh II Composition } \\
\text { (Oxygen-To-Metal } \\
\quad=1.875)\end{array}$ & 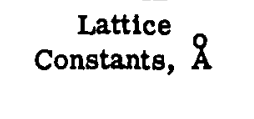 \\
\hline $17 \mathrm{UO}_{2.17} \cdot 18 \mathrm{Y}_{2} \mathrm{O}_{3}$ & $\begin{aligned} a & =10.002 \\
c & =9.362 \\
\text { Volume } & =817.09\end{aligned}$ & $17 \mathrm{UO}_{2.67} \cdot 18 \mathrm{Y}_{2} \mathrm{O}_{3}$ & Not measured \\
\hline $2 \mathrm{UO}_{2.36} \cdot 3 \mathrm{Y}_{2} \mathrm{O}_{3}$ & $\begin{aligned} a & =10.002 \\
c & =9.353 \\
\text { Volume } & =811.31\end{aligned}$ & $2 \mathrm{UO}_{3.0} \cdot 3 \mathrm{Y}_{2} \mathrm{O}_{3}$ & $\begin{aligned} a & =9.943 \\
c & =9.289 \\
\text { Volume } & =796.14\end{aligned}$ \\
\hline $4 \mathrm{UO}_{2.67} \cdot 9 \mathrm{Y}_{2} \mathrm{O}_{3}$ & $\begin{aligned} a & =9.967 \\
c & =9.338 \\
\text { Volume } & =804.25\end{aligned}$ & . & \\
\hline $\begin{array}{c}1 \mathrm{UO}_{3.0} \cdot 3 \mathrm{Y}_{2} \mathrm{O}_{3} \\
.\end{array}$ & $\begin{aligned} \mathrm{a} & =9.934 \\
\mathrm{c} & =9.364 \\
\text { Volume } & =801.13\end{aligned}$ & . & \\
\hline
\end{tabular}

The pseudo-fluorite lattice parameter for the rhombohedral phase ( $\mathrm{Rh}$ I) is compared in Figure 2.3 with the lattice parameters for the FCC phase. It can be noted that under oxidizing conditions, the limiting fluorite phase at $\mathrm{UO}_{3} \cdot 1.5 \mathrm{Y}_{2} \mathrm{O}_{3}\left(60 \mathrm{~mole} \% \mathrm{Y}_{2} \mathrm{O}_{3}\right)$ and the $\mathrm{Rh}$ I phase $\mathrm{UO}_{3} \cdot 3 \mathrm{Y}_{2} \mathrm{O}_{3}\left(75 \mathrm{~mole} \% \mathrm{Y}_{2} \mathrm{O}_{3}\right)$ have very little difference in cell volume.

Body-Centered Cubic Phase

Yttria crystallizes in a BCC structure (rare earth C-type). The solubility of uranla at high temperatures in this phase extends from about 14 mole percent $\mathrm{UO}_{2}\left(1 \mathrm{UO}_{2} \cdot 6 \mathrm{Y}_{2} \mathrm{O}_{3}\right)$ to 0 mole percent $\mathrm{UO}_{3}$. Low-temperature oxidation increases the solubility limit somewhat as indicated in Figure 2.4. From these data, it appears that the unit cell containing 16 molecules $\mathrm{Y}_{2} \mathrm{O}_{3}$ cannot accept more than about two additional oxygen atoms into its structure. This means that the maximum oxygen-to-metal ratio for BCC solid solutions ls about 1.56 at temperatures below $1000^{\circ} \mathrm{C}$.

The BCC solid solution is not stable in air at temperatures above $1000^{\circ} \mathrm{C}$; therefore, the preparation of a homogeneous solid solution requires reaction in hydrogen at high temperatures. The 87.5 mole percent $\mathrm{Y}_{2} \mathrm{O}_{3}$ composition was prepared in the oxidized state by low-tcmperature oxidation afler redction in hydrogen at $1700^{\circ} \mathrm{C}$. Oxidation of the $\mathrm{BCC}$ powder 


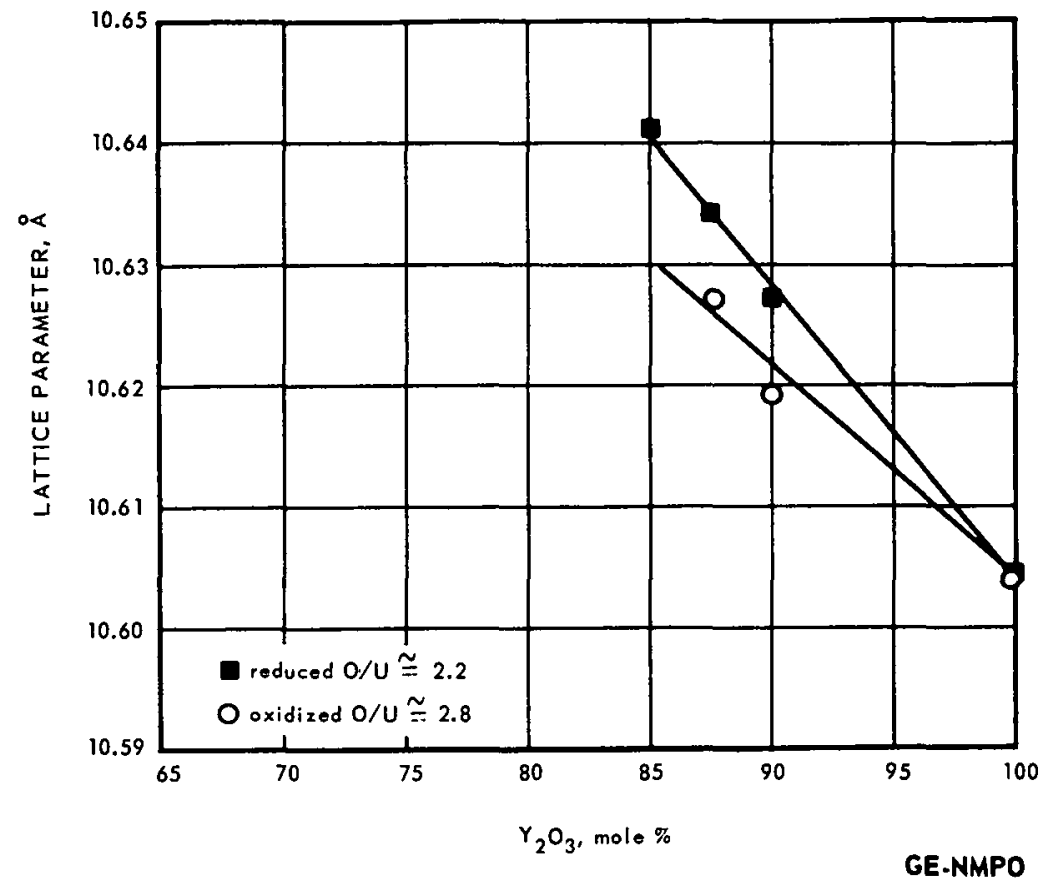

Fig. 2.4 - Lattice parameters of BCC solid solution of $\mathrm{UO}_{2}-\mathrm{Y}_{2} \mathrm{O}_{3}$

(average surface area of $0.08 \mathrm{~m}^{2} / \mathrm{g}$ ) readily occurred at temperatures above $400^{\circ} \mathrm{C}$. The behavior of the BCC solid solution is shown in Table 2.4 after various heat treatments. Oxidation at temperatures below $815^{\circ} \mathrm{C}$ resulted in an increase in the oxygen-to-uranium ratio of 0.67 . After further oxidation at temperatures above $1100^{\circ} \mathrm{C}$, this increase in the oxygento-uranium ratio was 0.85 as a result of the decomposition of the $\mathrm{BCC}$ solid solution to essentially free $\mathrm{Y}_{2} \mathrm{O}_{3}$ and $\mathrm{Rh}$ I phase. The Rh I phase ( 75 mole percent $\mathrm{Y}_{2} \mathrm{O}_{3}$ ), which contains nearly all of the uranium, has an oxygen-to-uranium ratio of about 3.0 at temperatures below $1300^{\circ} \mathrm{C}$. By difference, the initial oxygen-to-uranium ratio must be about 2.15 which is consistent with the oxygen-to-uranium ratios determined by chemical analysis for

TABLE 2.4

BEHAVIOR OF COPRECIPITATED UO $2+\mathrm{x}^{\cdot} 7 \mathrm{Y}_{2} \mathrm{O}_{3}\left(87.5\right.$ mole $\% \mathrm{Y}_{2} \mathrm{O}_{3}$ ) SOLID SOLUTION AFTER VARIOUS HEAT TREATMENTS

\begin{tabular}{|c|c|c|c|c|c|c|}
\hline Experiment & $\begin{array}{l}\text { Original } \\
\text { Material }\end{array}$ & Atmosphere & $\begin{array}{c}\text { Temperature, } \\
{ }^{\circ} \mathrm{C}\end{array}$ & $\begin{array}{l}\text { Time, } \\
\text { min }\end{array}$ & $\begin{array}{l}\text { Change In Oxygen- } \\
\text { To-Uranium Ratio }\end{array}$ & $\begin{array}{c}\text { X-Ray Diffraction } \\
\text { Analysis }\end{array}$ \\
\hline 1 & Coprectpitated $^{2}$ & Atr & 815 & 860 & - & BCC SS \\
\hline 2 & $\begin{array}{l}\text { Material from } \\
\text { experiment } 1\end{array}$ & Air & 1400 & 3600 & - & $\begin{array}{l}50 \% \text { Rh I } \\
50 \% \text { Freo } \mathrm{Y}_{2} \mathrm{O}_{3}\end{array}$ \\
\hline 3 & Coprecipltated & $\mathrm{H}_{2}$ & 1700 & 720 & - & BCC $\$ s$ \\
\hline 4 & $\begin{array}{l}\text { Material from } \\
\text { experiment } 3\end{array}$ & $\mathrm{O}_{2}(140 \mathrm{~mm})$ & 850 & 1750 & 0.67 & BCC SS \\
\hline 5 & $\begin{array}{l}\text { Materialb from } \\
\text { experiment } 3\end{array}$ & $\mathrm{O}_{2}(130 \mathrm{~mm})$ & 816 & 910 & 0.67 & Not determined \\
\hline 6 & $-b$ & $\mathrm{O}_{2}(130 \mathrm{~mm})$ & 1315 & 2710 & 0.85 & Not determined \\
\hline 7 & $-b$ & $\mathrm{O}_{2}(130 \mathrm{~mm})$ & 816 & 300 & 0.85 & $\begin{array}{l}50 \% \text { Rh I } \\
50 \% \text { Free } \mathrm{Y}_{2} \mathrm{O}_{3}\end{array}$ \\
\hline
\end{tabular}

aThe starting material was coprecipitated as $1 \mathrm{UO}_{2+\mathrm{x}} \cdot 7 \mathrm{Y}_{2} \mathrm{O}_{3}$ by adding $\mathrm{NH}_{4} \mathrm{OH}$ solution to a stirred aqueous solution of uranyl and yttrium nitrates. The product is probably a mixed crystal of diammonium uranate and yttrium hydroxide. Calcination was essentlally complete in air at $800^{\circ} \mathrm{C}$ in a few hours.

hExperiments 5,0 , and 7 were performed sequentially on the same material. 
$\mathrm{BCC}$ solid solutions reduced at $1700^{\circ} \mathrm{C}$. The maximum oxidation state of the uranium in the $\mathrm{BCC}$ phase at temperatures below the decomposition temperature must then be about 2.8.

A plot of the change in lattice parameter of the pseudo-fluorite cell (one-half the lattice parameter of the BCC unit cell) with urania content is given in Figure 2.4. The contraction which accompanies oxidation of these solid solutions was very small.

The FCC and BCC solid solutions coexist over a small region of the phase diagram at low oxygen-to-uranium ratios $(<2.1)$. Samples containing both phases will oxidize at temperatures below $1000^{\circ} \mathrm{C}$ without a phase change; in fact, oxidation at low temperatures produces no crystal transformation over the whole composition region studied. Temperatures above $1000^{\circ} \mathrm{C}$ are required to give the cations enough mobility to rearrange into a different structure.

System Above $1700^{\circ} \mathrm{C}$

Studies of the phase relationships in the $\mathrm{UO}_{2}-\mathrm{UO}_{3}-\mathrm{Y}_{2} \mathrm{O}_{3}$ system at temperatures in the range of $1700^{\circ}$ to $2000^{\circ} \mathrm{C}$ were limited to the determination of the phase relationships at the $\mathrm{UO}_{2+\mathrm{x}} \cdot 3 \mathrm{Y}_{2} \mathrm{O}_{3}$ composition.

Pressed $\mathrm{UO}_{2.9} \cdot 3 \mathrm{Y}_{2} \mathrm{O}_{3}$ pellets were heated for 2 to 4 hours in a closed crucible of the same composition. The furnace atmosphere consisted of about 90-percent argon and about 10-percent air. The phases present and the oxygen-to-uranium ratios were determined by $\mathrm{X}$-ray diffraction and chemical analysis. Table 2.5 summarizes the experimental data and includes data for the same composition heated in flowing oxygen (oxygen-to-uranium ratio 2.7 to 2.8 ) at comparable temperatures.

TABLE 2.5

PHASES PRESENT AS A FUNCTION OF OXYGEN-TO-URANIUM RATIO

FOR THE $\mathrm{UO}_{2+\mathrm{x}} \cdot 3 \mathrm{Y}_{2} \mathrm{O}_{3}$ COMPOSITION AFTER HEATING AT HIGH TEMPERATURES

\begin{tabular}{cccl}
\hline $\begin{array}{c}\text { Temperature, } \\
\text { OC }\end{array}$ & Atmosphere & $\begin{array}{c}\text { Oxygen-To-Uranium } \\
\text { Ratio }\end{array}$ & \multicolumn{1}{c}{ Phases Present } \\
\hline 1800 & Oxygen & 2.78 & Rh I + BCC \\
& Argon - Air & 2.25 & $60 \%$ BCC + 40\% FCC \\
1900 & Oxygen & 2.78 & Rh I + BCC \\
& Argon - Atr & 2.27 & Major BCC - Minor FCC \\
2000 & Argon - Atr & 2.24 & Major BCC - Minor FCC \\
& Oxygen & 2.73 & Major Rh I - Minor BCC \\
& Oxygen & 2.76 & Major Rh I - Minor BCC \\
& Argon - Atr & 2.07 & Major BCC + Minor FCC \\
\hline
\end{tabular}

The results indicate that at temperatures above $1700^{\circ} \mathrm{C}$ a broadening of the $\mathrm{FCC}$ and $\mathrm{BCC}$ region to higher oxygen-to-uranium ratios occurs in the vicinity of the $\mathrm{UO}_{2}+\mathrm{x}^{\cdot} 3 \mathrm{Y}_{2} \mathrm{O}_{3} \mathrm{com}$ position. At temperatures of $1700^{\circ} \mathrm{C}$ and below, the two-phase $\mathrm{BCC}$ and FCC region extends only to oxygen-to-uranium ratios of about 2.10 . 


\section{3. $\mathrm{UO}_{2.9} \cdot 3 \mathrm{Y}_{2} \mathrm{O}_{3}$ COMPOSITION}

\subsection{FABRICATION}

\section{Preparation of Powder}

Early work 16 on the mechanism and kinetics of forming $\mathrm{UO}_{2} .9 \cdot 3 \mathrm{Y}_{2} \mathrm{O}_{3}$ showed that, if the material had full access to air, the reaction between $\mathrm{UO}_{2}$ and $\mathrm{Y}_{2} \mathrm{O}_{3}$ is complete in 24 hours at $1360^{\circ} \mathrm{C}$. Subsequent studies on this reaction resulted in a process whereby the $\mathrm{UO}_{2}$ and $\mathrm{Y}_{2} \mathrm{O}_{3}$ were mixed by milling for 30 minutes in a vibratory mill and then reacted for 8 hours at $1375^{\circ} \mathrm{C}$ in air. After reaction at this temperature, the material had an oxygento-uranium ratio of 2.98 to 3.0 . The reacted material was milled for 4 hours in a vibr:tory mill to produce a sinterable powder with a surface area of 0.025 square meters per gram (measured by the BET method using krypton gas). This reacted and milled $\mathrm{UO}_{2.9^{\circ}}$ $3 \mathrm{Y}_{2} \mathrm{O}_{3}$ powder is then suitable for subsequent processing into test bodies by pressing or by extrusion.

Vibratory milling was selected for processing reacted $\mathrm{UO}_{2}+\mathrm{x}^{\cdot} 3 \mathrm{Y}_{2} \mathrm{O}_{3}$ because earller work ${ }^{17}$ showed that this method was more efficient than rotary milling. The powder, grinding media, and vehicle were put into the mill chamber, a rubber-lined steel container. This container was vibrated by a conventional 3.8-liter (1-gallon)-capacity paint conditioner, which has a three-dimensional, high-frequency ( 650 cycles per minute), high-amplitude vibration.

The grinding media used was sintered $\mathrm{Y}_{2} \mathrm{O}_{3}$ pellets about 0.32 centimeter ( $1 / 8$ inch) in diameter and about 0.32 centimeter $(1 / 8 \mathrm{inch})$ in length; the vehicle used was water. The mill was loaded to about 65 percent capacity.

The comminution variables studied were (1) the volume ratio of $\mathrm{UO}_{2} .9^{\cdot} 3 \mathrm{Y}_{2} \mathrm{O}_{3}$ to grinding media, (2) the volume ratio of water to $\mathrm{UO}_{2.9} \cdot 3 \mathrm{Y}_{2} \mathrm{O}_{3}$, and (3) the milling time. The sinterability of the milled powder was determined by pressing 0.95 -centimeter $(3 / 8$-inch)-diameter, 1.27 -centimeter $\left(1 / 2\right.$-inch)-long pellets at $281 \mathrm{~kg} / \mathrm{cm}^{2}(4000 \mathrm{ps})$ in a steel die, by 1 sostatically compacting at $1406 \mathrm{~kg} / \mathrm{cm}^{2}(20,000 \mathrm{ps})$, and by sintering for 4 hours at $1730^{\circ}$ to $1750^{\circ} \mathrm{C}$ in oxygen. The $\mathrm{Y}_{2} \mathrm{O}_{3}$ increase from the grinding media was determined by wet chemistry.

Figure 3.1 shows the effect of varying the grinding media-to- $\mathrm{UO}_{2} . \theta^{\circ} \cdot 3 \mathrm{Y}_{2} \mathrm{O}_{3}$ ratio on sintered density and $\mathrm{Y}_{2} \mathrm{O}_{3}$ increase. The results show that a volume ratio of about 3.6:1 (grinding media-to- $\mathrm{UO}_{2 .} \cdot 3 \mathrm{Y}_{2} \mathrm{O}_{3}$ ) is sufficient for the desired density.

The effect of the $\mathrm{UO}_{2.9} \cdot 3 \mathrm{Y}_{2} \mathrm{O}_{3}$-to-water ratio on sintered density is given in Figure 3.2. These data indicate that a ratio of water to $\mathrm{UO}_{2} .9 \cdot 3 \mathrm{Y}_{2} \mathrm{O}_{3}$ of between $2: 1$ and $3: 1$ by volume is suitable to produce sinterable powder. However, a ratio greater than 2.5:1 causes a rapid increase in $\mathrm{Y}_{2} \mathrm{O}_{3}$ contamination.

Figure 3.3 shows the effect of milling time on sinterability. Milling times of between 2 and 4 hours are sufficient to produce sinterable powders, and the material has less than 1.5 percent $\mathrm{Y}_{2} \mathrm{O}_{3}$ contamination. 


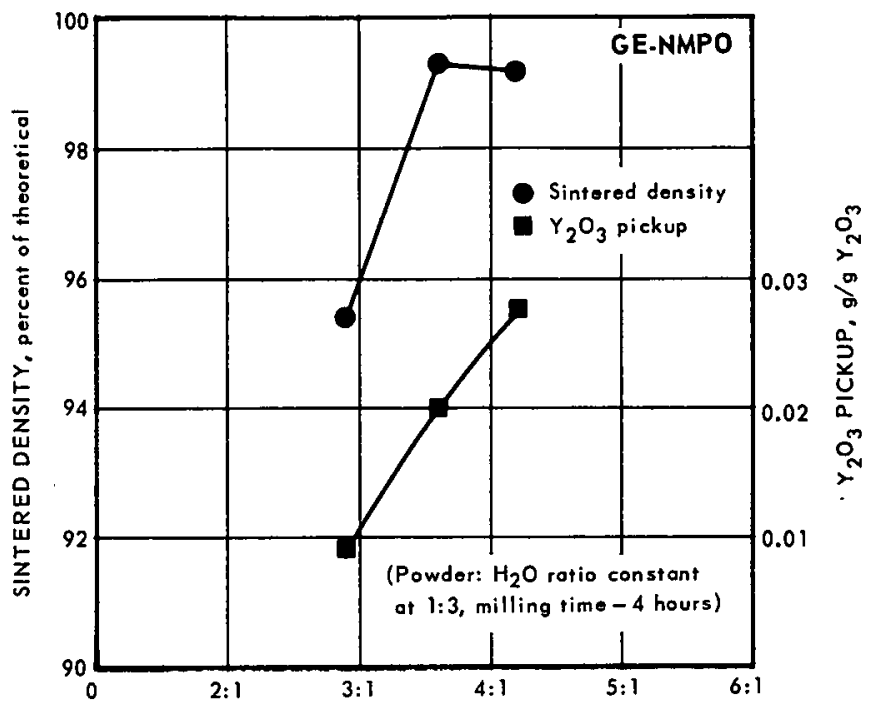

VOLUME RATIO OF GRINDING MEDIA TO POWDER

Fig. 3.1 - Effect of grinding media-to-powder ratio on sintered density and $\mathrm{Y}_{2} \mathrm{O}_{3}$ pickup

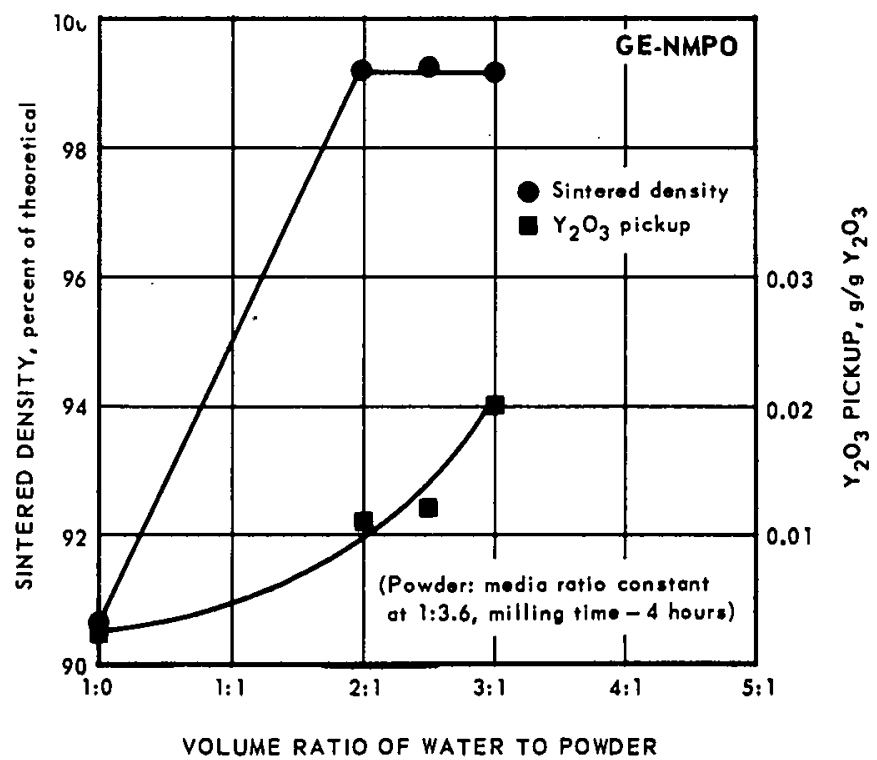

Fig. 3.2-Effect of water-to-powder ratio on sintered density and $\mathrm{Y}_{2} \mathrm{D}_{3}$ pickup 


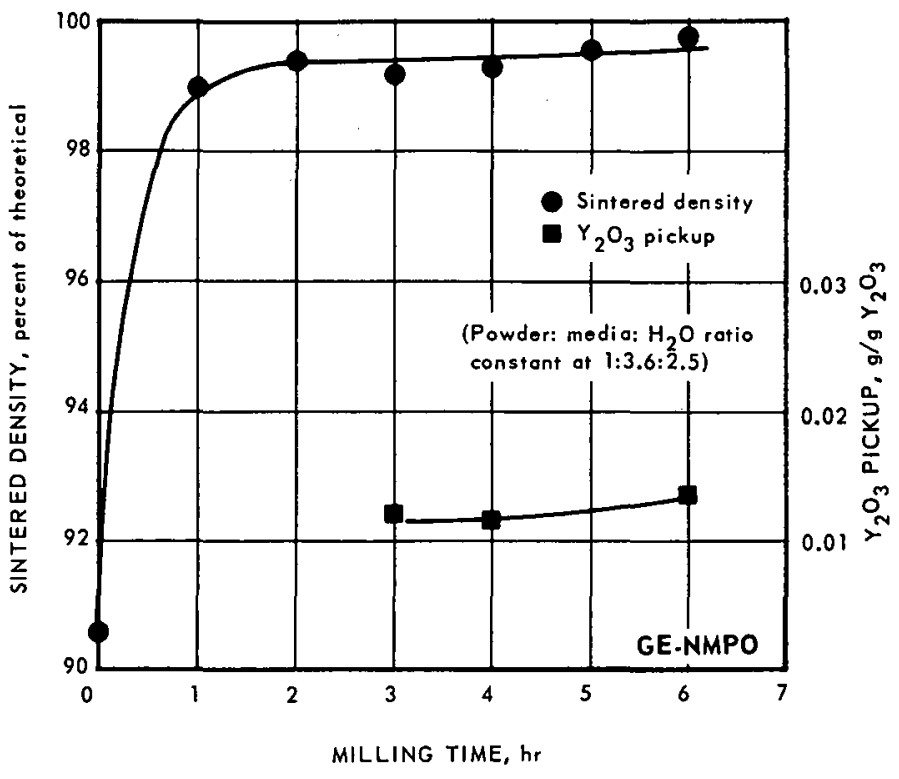

Fig. 3.3-Effect of milling time on sintered density and $\mathrm{Y}_{2} \mathrm{O}_{3}$ pickup

Based on these results, the milling process selected was a volume ratio of $1 \mathrm{UO}_{2.9^{\circ}}$ $3 \mathrm{Y}_{2} \mathrm{O}_{3}$ to 3.6 media to 2.5 water, with a 4-hour milling time. The $\mathrm{Y}_{2} \mathrm{O}_{3}$ contamination of about 1.2 weight percent (based on the $\mathrm{Y}_{2} \mathrm{O}_{3}$ content of the $\mathrm{UO}_{2.9} \cdot 3 \mathrm{Y}_{2} \mathrm{O}_{3}$ powder) is compensated by adjusting the starting $\mathrm{UO}_{2} .9 \cdot 3 \mathrm{Y}_{2} \mathrm{O}_{3}$ composition.

\section{Cold Pressing}

Pieces such as pellets, thermal conductivity specimens, and other bodies of similar shape may be formed by dry pressing in a steel die at $352 \mathrm{~kg} / \mathrm{cm}^{2}(5000 \mathrm{psi})$ followed by isostatic pressing at $1406 \mathrm{~kg} / \mathrm{cm}^{2}(20,000 \mathrm{psi})$. Use of about 2 weight percent Mobilicer " $R$ " Wax as a binder facilitated handling.

\section{Extrusion and Coextrusion}

A plastic dispersion mass of the $\mathrm{UO}_{2.9} \cdot 3 \mathrm{Y}_{2} \mathrm{O}_{3}$ composition was developed for use in coextruding this material as the inside diameter cladding on $\mathrm{BeO}$ tubes. The best plasticizer developed was an aqueous solution of mixed polymers modified with glycerine. The polymers used were hydroxymethyl cellulose (a strongly cross-linked polymer) and polyacrylamide (a linear chain polymer).

The pressure - flow relationships of four different $\mathrm{UO}_{2.9} \cdot 3 \mathrm{Y}_{2} \mathrm{O}_{3}$ plastic dispersion masses are shown in Figures 3.4, 3.5, 3.6, and 3.7 to illustrate development of a plastic dispersion mass of this material. Figure 3.4 shows the flow properties using polyacrylamide as a plasticizer. The erratic behavior shown in the flow causes a "chattering" of the material during coextrusion with $\mathrm{BeO}$, and results in non-uniformity of cladding thickness. Using glycerine to replace part of the polyacrylamide and part of the water results in a smooth pressure versus flow curve (Figure 3.5), but this plasticizer requires a high pressure change to give relatively low changes in flow rate. This causes excessive pressure to develop during coextrusion.

The other extreme of very rapid changes in flow with small changes in pressure occurs with hydroxymethyl cellulose, as shown in Figure 3.6 (only shown as modified with glycerine). By combining these two systems, a more desirable flow curve is obtained, as shown in Figure 3.7. 


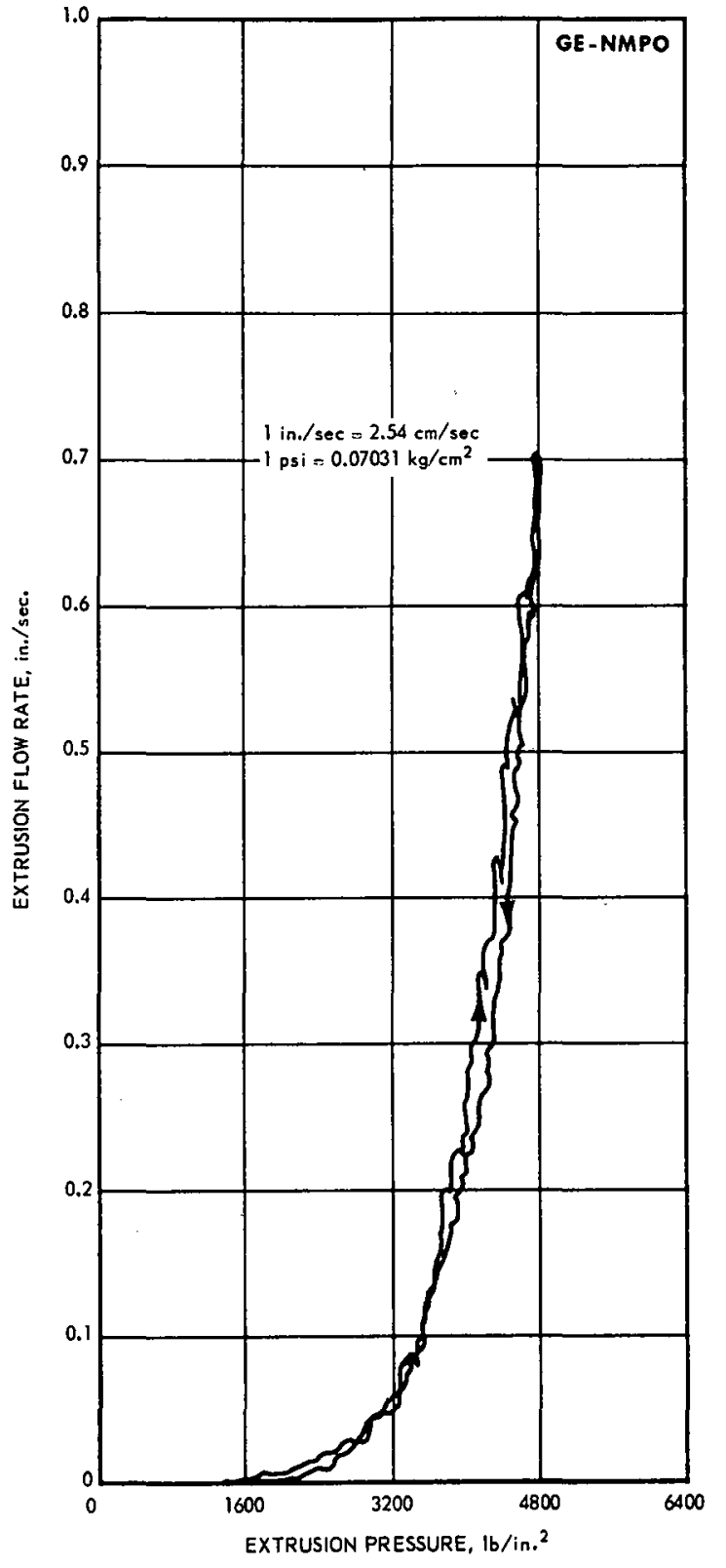

Fig. 3.5-Extrusion pressure versus extrusion flow rate of $\mathrm{UO}_{2+\mathrm{x}} \cdot 3 \mathrm{Y}_{2} \mathrm{O}_{3}$ dispersed in a solution of 15 percent polyacrylamide, 20 percent glycerine, and 65 percent $\mathrm{H}_{2} \mathrm{O}$
Fig. 3.4-Extrusion pressure versus extrusion flow rate of $\mathrm{UO}_{2+\mathrm{x}} \cdot 3 \mathrm{Y}_{2} \mathrm{O}_{3}$ dispersed in a solution of 20 percent polyacrylamide in $\mathrm{H}_{2} \mathrm{O}$

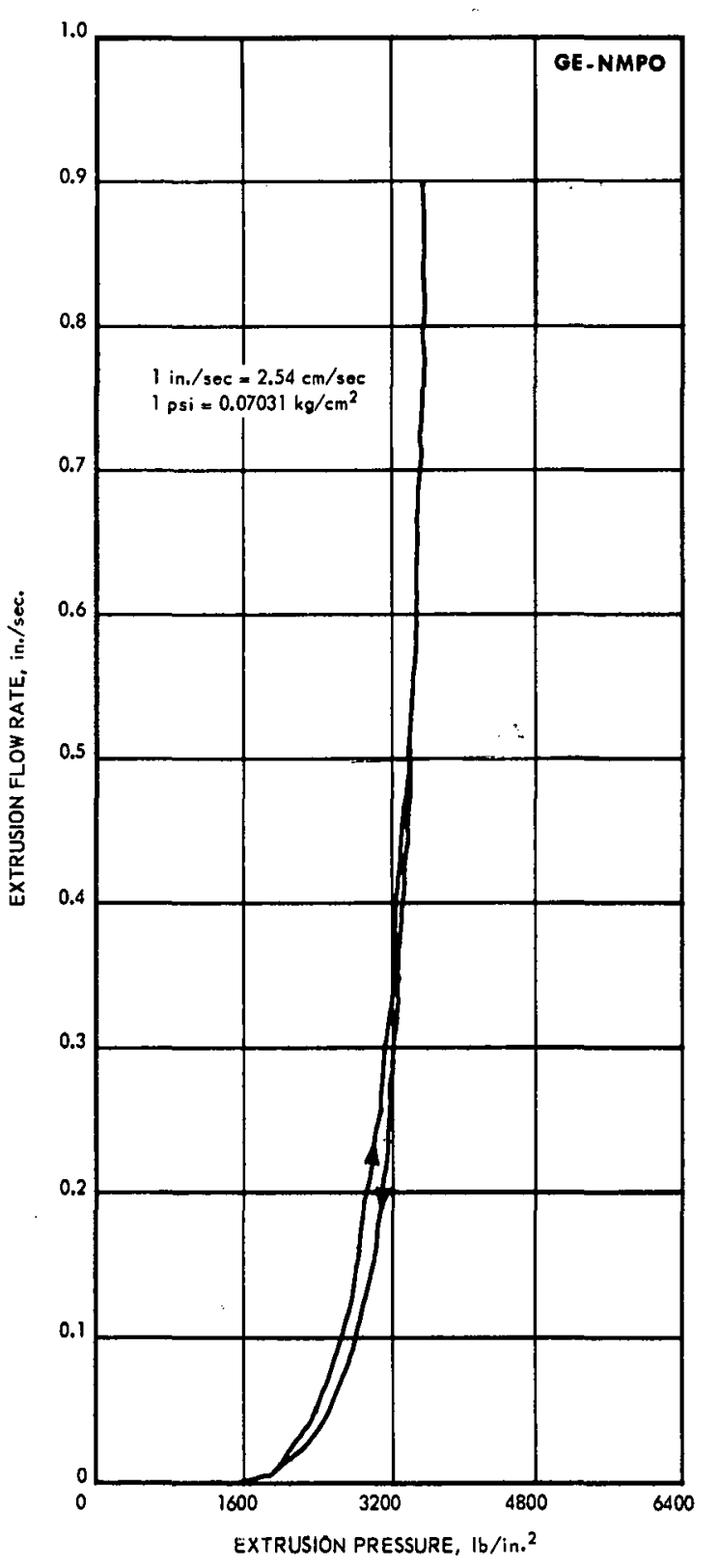




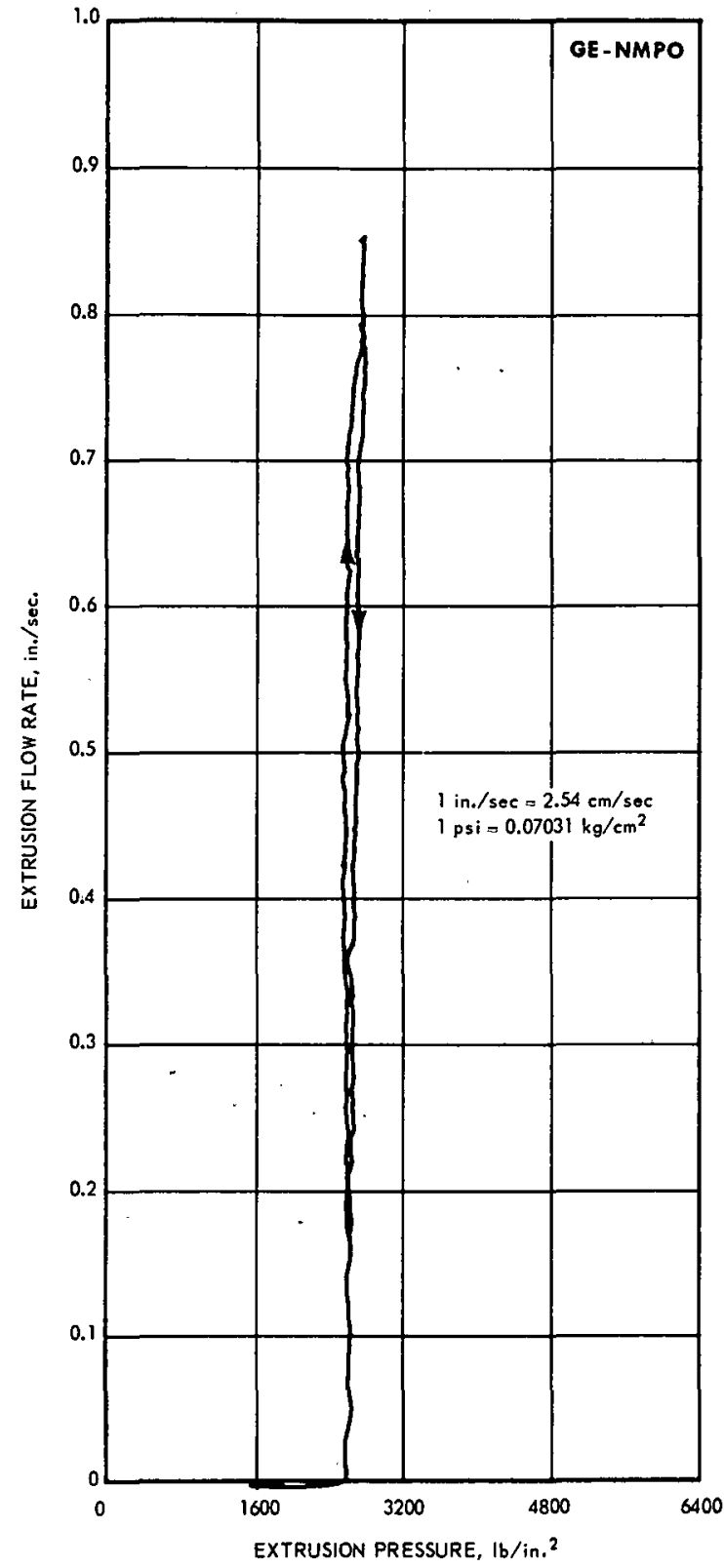

Fig. 3.7-Extrusion pressure versus extrusion flow rate of $\mathrm{UO}_{2+\mathrm{x}} \cdot 3 \mathrm{Y}_{2} \mathrm{O}_{3}$ dispersed in a solution of 4 percent polyacrylamide, 10 percent hydroxy-methyl cellulose, 6.7 percent glycerine, and 79.3 percent $\mathrm{H}_{2} \cap$
Fig. 3.6-Extrusion pressure versus extrusion flow rate of $\mathrm{UO}_{2+\mathrm{x}} \cdot 3 \mathrm{Y}_{2} \mathrm{O}_{3}$ dispersed in a solution of 15 percent hydroxy-methyl cellulose, 20 percent glycerine, and 65 percent $\mathrm{H}_{2} \mathrm{O}$

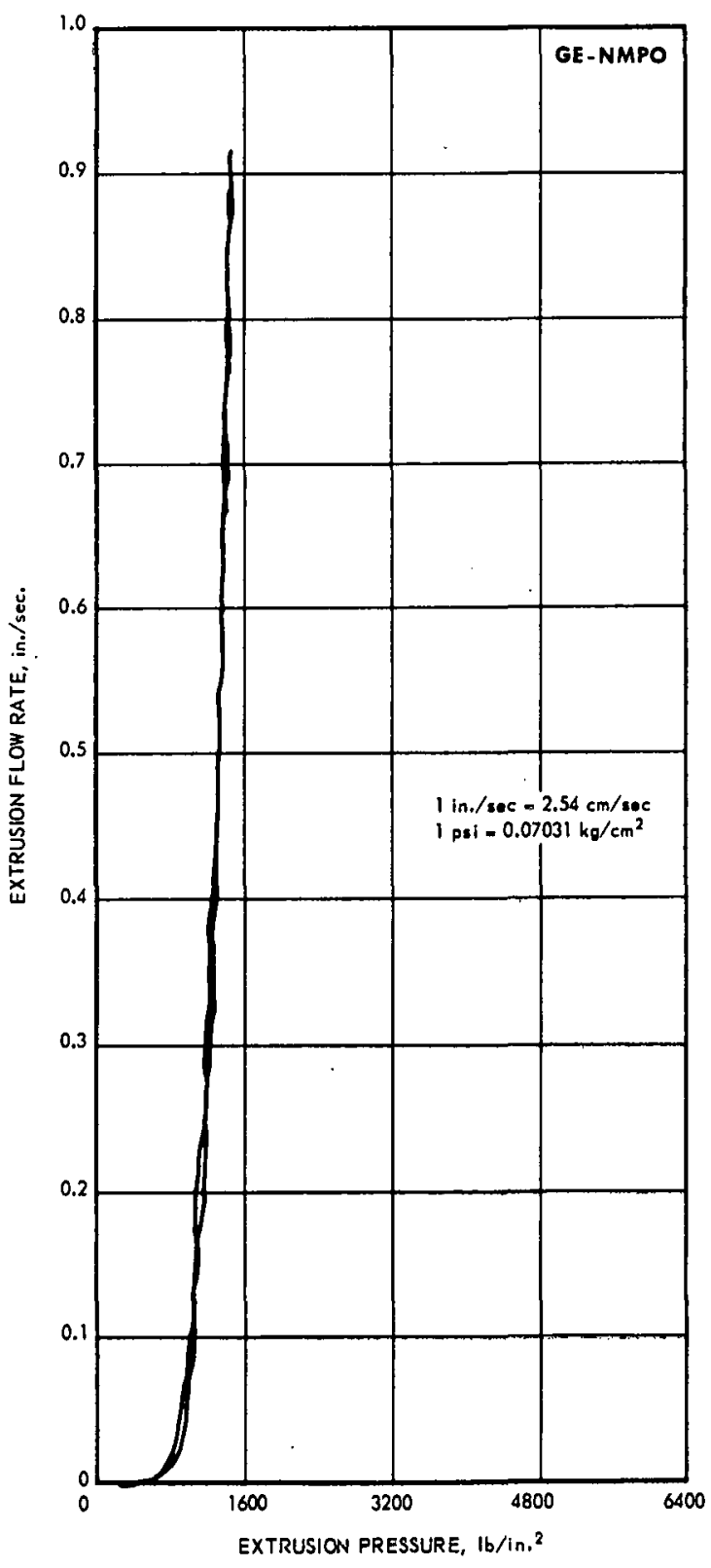


These effects can be expressed in terms of the differences between pressures required to give flow rates of 0.25 centimeter $(0.1 \mathrm{inch})$ per second and 1.25 centimeter $(0.5 \mathrm{inch})$ per second for each material. The pressure differences are $65,1.1$, and $22.5 \mathrm{~kg} / \mathrm{cm}^{2}$ (930, 15, and $320 \mathrm{psi})$, respectively, for the polyacrylamide, hydroxymethyl cellulose, and the mixture of the two polymers.

\section{Dip Coating}

A procedure was developed for applying a BeO cladding to the inside diameter of coextruded $\mathrm{BeO}-\mathrm{UO}_{2.9} \cdot 3 \mathrm{Y}_{2} \mathrm{O}_{3}$ tubes so that fission product release is inhibited during irradiation tests. This process was a dip-coating technique using approximately 1 weight percent ammonium alginate in water to give a suspension of the $\mathrm{BeO}$. Vibratory milling of the $\mathrm{BeO}$ increased the density of the cladding and produced a smoother, more uniform coating. As shown in Figure 3.8, the cladding is continuous and dense (estimated 2 to 4 percent porosity). Cladding thickness measured at sections cut from opposite ends of a tube was $0.058 \pm 0.0025$ millimeter $(0.0023 \pm 0.0001$ inch $)$.

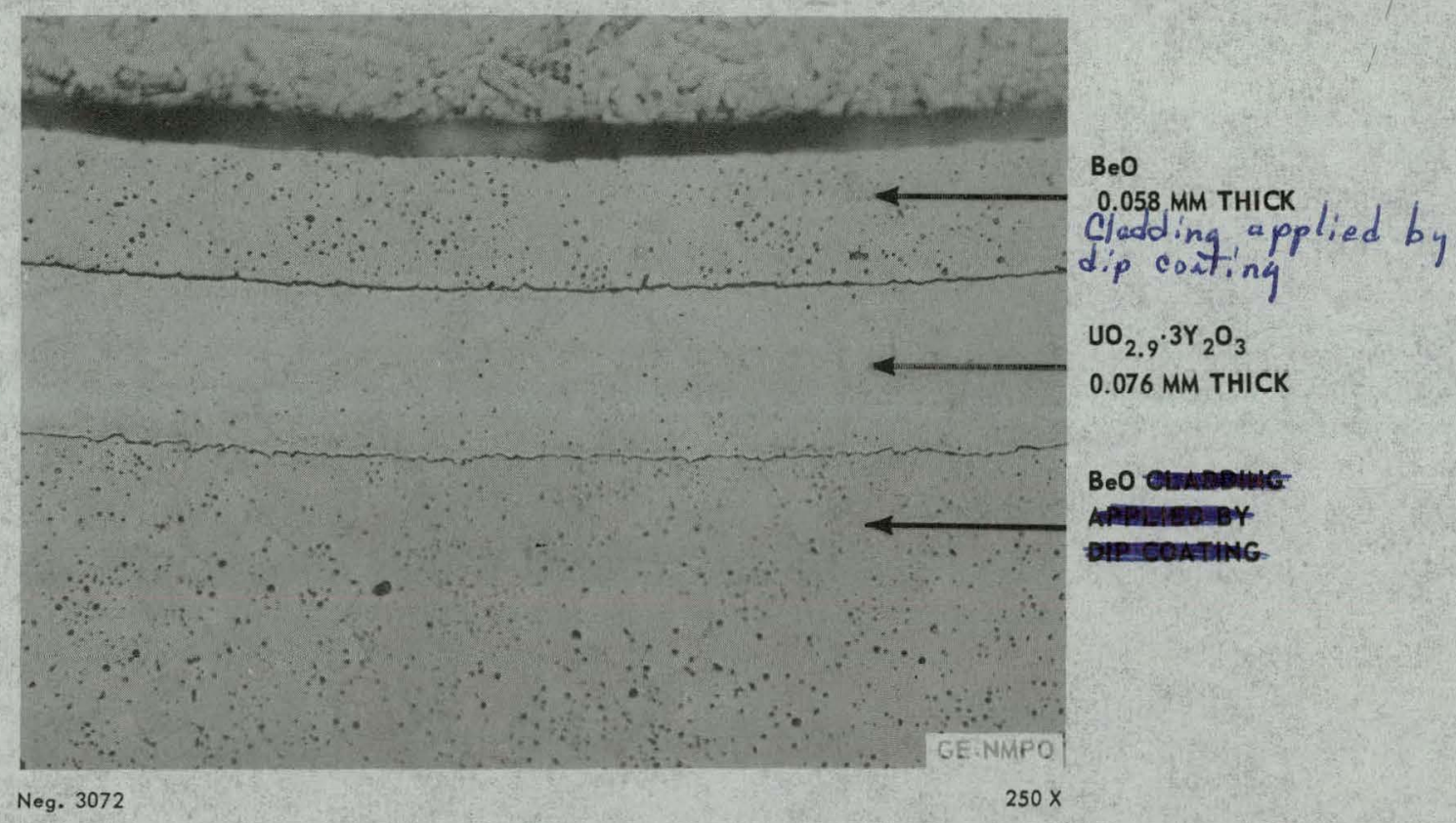

Fig. 3.8-Coextruded $\mathrm{BeO}-\mathrm{UO}_{2.9} \cdot 3 \mathrm{Y}_{2} \mathrm{O}_{3}$ tube dip coated with $\mathrm{BeO}$ cladding and sintered for 2 hours at $1650^{\circ} \mathrm{C}$ in air

\section{Sintering}

The milled $\mathrm{UO}_{2.9} \cdot 3 \mathrm{Y}_{2} \mathrm{O}_{3}$ powder sinters to about 99.7 percent of theoretical density after 3 hours at $1750^{\circ} \mathrm{C}$ in an oxygen atmosphere. The oxygen-sintered material shows about 5 percent or less body-centered cubic (BCC) phase to be present. The grain size of the material is about 6 microns. A photomicrograph of a typical structure is shown in Figure 3.9.

Sintering in a hydrogen atmosphere for about 12 hours at $1700^{\circ} \mathrm{C}$ produces a structure composed of the rhombohedral reduced phase plus a body-centered cubic phase. The density is about 99.1 percent of theoretical with an oxygen-to-uranium ratio of about 2.20 . The grain size is about 3 microns. Subsequent oxidation of the sintered part changes the oxygen- 
to-uranium ratio to 2.9 to 3.0 depending on the temperature at which the oxidation is equilibrated. A typical microstructure of hydrogen-sintered $\mathrm{UO}_{2} .2^{\circ} 3 \mathrm{Y}_{2} \mathrm{O}_{3}$ is shown in Figure 3.10. The structure after subsequent oxidation at $1450^{\circ} \mathrm{C}$ is shown in Figure 3.11 .

\section{2 CHEMICAL AND PHYSICAL PROPERTIES}

Fuel Retention and Phase Stability

Microstructural studies, X-ray diffraction, and chemical analyses were used to evaluate the high-temperature stability of the rhombohedral $\mathrm{UO}_{2.9} \cdot 3 \mathrm{Y}_{2} \mathrm{O}_{3}$ composition. Specimens, both sintered pellets and powders, were heated for extended times in oxidizing atmospheres at temperatures of $1650^{\circ}$ to $2000^{\circ} \mathrm{C}$. The $\mathrm{UO}_{2}$ loss and structure change data for sintered pellet specimens are summarized in Table 3.1 for various times in oxidizing atmospheres (air or oxygen) at $1700^{\circ}$ to $2000^{\circ} \mathrm{C}$.

TABLE 3.1

COMPOSITION AND PHASES PRESENT FOR UO $2.9^{\cdot} 3 \mathrm{Y}_{2} \mathrm{O}_{3}$ PELLETS AFTER HIGH-TEMPERATURE TESTS IN OXIDIZING ATMOSPHERES

\begin{tabular}{|c|c|c|c|c|c|}
\hline \multirow{2}{*}{$\begin{array}{l}\text { Temperature, } \\
{ }^{\mathrm{O}} \mathrm{C}\end{array}$} & \multirow{2}{*}{$\begin{array}{l}\text { Time, } \\
\text { hr }\end{array}$} & \multirow{2}{*}{$\begin{array}{l}\text { Oxygen-To- } \\
\text { Uranium Ratio }\end{array}$} & \multirow{2}{*}{$\mathrm{UO}_{2.9}$ Loss, $\%$} & \multicolumn{2}{|l|}{ Phases Present } \\
\hline & & & & Exterior & Interior \\
\hline As-sintered & - & 2. 92 & $-\quad-\quad 1$ & $\begin{array}{l}\text { Rhombohedral (Rh I) } \\
\text { Trace body-centered cubic } \\
\text { (BCC) }\end{array}$ & Rh I, Trace BCC \\
\hline \multirow[t]{3}{*}{1700 (air) } & 100 & 2. 91 & nil & Rh I, Trace BCC & \\
\hline & 500 & 2. 92 & nil & $\begin{array}{l}\text { Major BCC } \\
\text { Minor Rh I }\end{array}$ & $\begin{array}{l}\text { Major Rh I } \\
\text { Trace BCC }\end{array}$ \\
\hline & 1005 & 2. 90 & 2.9 & $\begin{array}{l}\text { Major } \mathrm{BCC} \\
\text { Trace unidentified }\end{array}$ & $\begin{array}{l}\text { Major Rh I } \\
\text { Trace BCC }\end{array}$ \\
\hline \multirow[t]{2}{*}{$1850\left(\mathrm{O}_{2}\right)$} & 19 & 2. 85 & 6. 0 & Rh I, BCC, Trace unidentified & Rh I, Trace BCC \\
\hline & 23 & - & - & $\begin{array}{l}\text { Rh I, BCC, Possible face- } \\
\text { centered cubic (FCC) }\end{array}$ & Rh I, BCC \\
\hline \multirow[t]{2}{*}{$1900\left(\mathrm{O}_{2}\right)$} & 11 & 2. 79 & 6. 6 & $\begin{array}{l}\text { Major Rh I } \\
\text { Minor BCC }\end{array}$ & $\begin{array}{l}\text { Major Rh I } \\
\text { Minor BCC }\end{array}$ \\
\hline & 17 & 2. 79 & 2. 9 & $\begin{array}{l}\text { Major Rh I } \\
\text { Minor BCC }\end{array}$ & $\begin{array}{l}\text { Major Rh I } \\
\text { Minor BCC }\end{array}$ \\
\hline \multirow[t]{2}{*}{$2000\left(\mathrm{O}_{2}\right)$} & 1 & 2. 80 & 1. 3 & $50 \% \mathrm{BCC}-50 \%$ Rh I & Rh I \\
\hline & 5 & 2. 80 & 1.3 & $\mathrm{BCC}-\mathrm{Rh} I$ & Rh I \\
\hline
\end{tabular}

The samples which were tested at $1800^{\circ} \mathrm{C}$ and higher picked up a small amount (1 to 2 wt $\%$ ) of $\mathrm{ZrO}_{2}$ from the furnace fixtures. The effect, if any, of this contamination was not determined.

The data, summarized in Table 3.1, show the following:

1. After 500 hours at $1700^{\circ} \mathrm{C}$, no loss of $\mathrm{UO}_{2}$ was detected by chemical analysis. However, X-ray diffraction analysis of polished sections showed the presence of a second phase determined to be body-centered cubic (BCC) solid solution. The oxygen-touranium ratio of 2.92 for the specimen and the identification of the second phase are in agreement with the phase diagram shown in Figure 2.1. After 1000 hours at $1700^{\circ} \mathrm{C}$, the surface of the specimen was depleted of $\mathrm{UO}_{2}$, resulting in a single, $\mathrm{Y}_{2} \mathrm{O}_{3}$-rich BCC phase. 


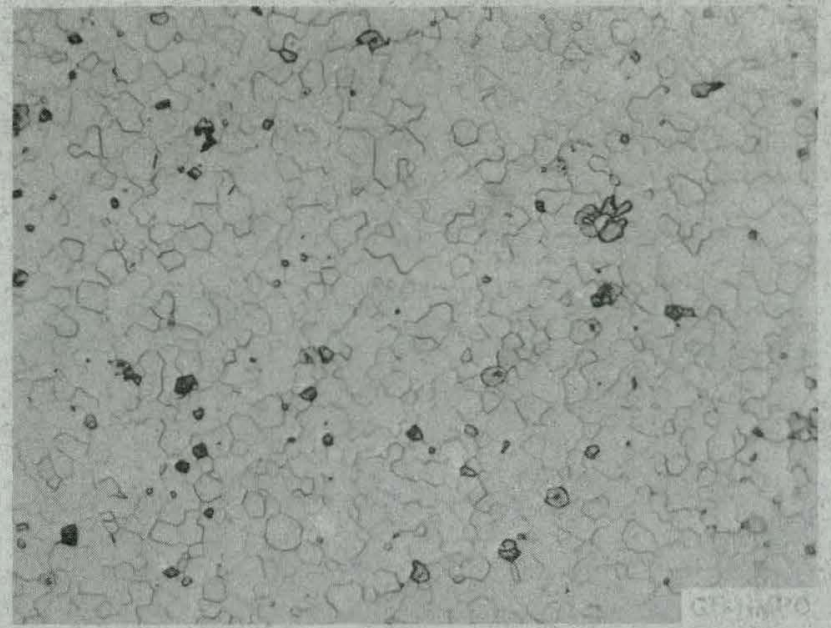

Neg. 555

$500 x$

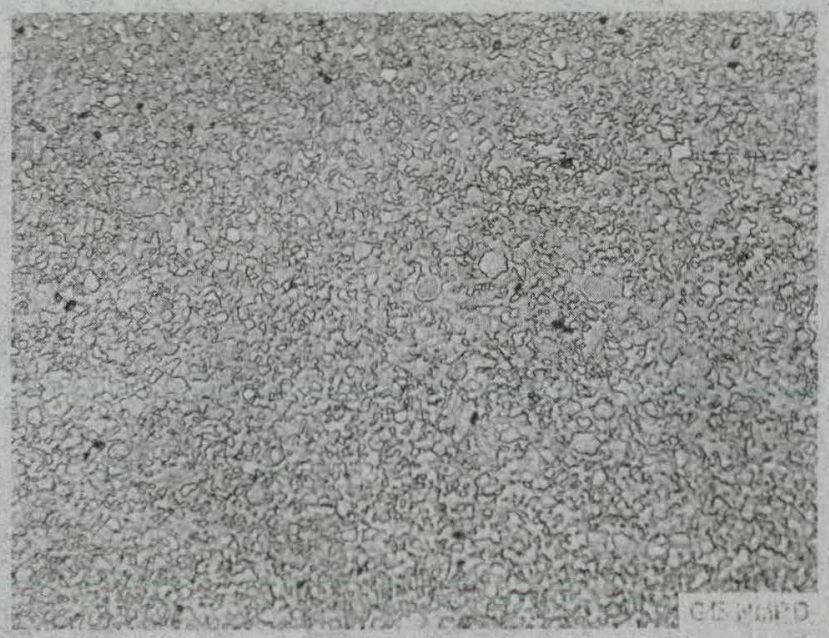

Neg. 461

$500 x$

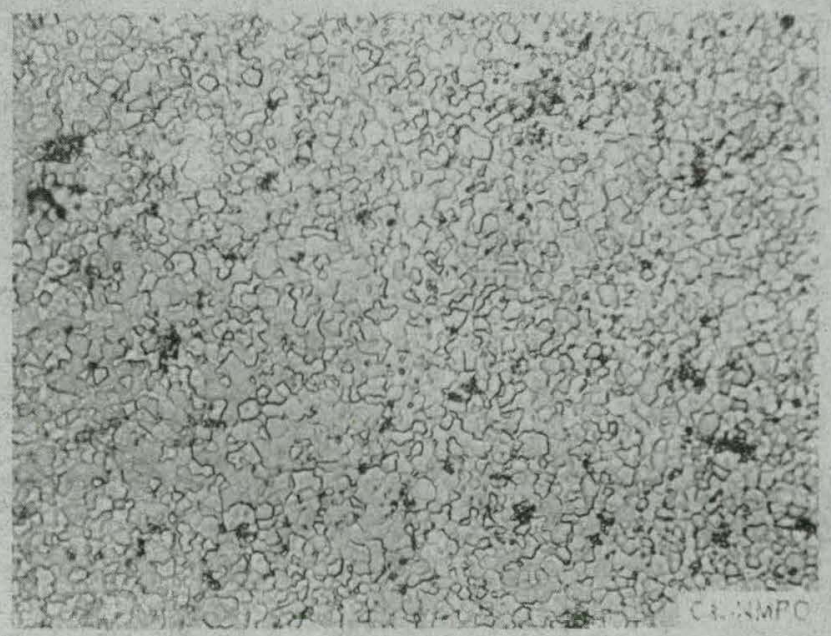

Fig. 3.9-Microstructure of milled $\mathrm{UO}_{2.9} \cdot 3 \mathrm{Y}_{2} \mathrm{O}_{3}$ powder sintered in oxygen for 3 hours at $1750^{\circ} \mathrm{C}$

Etched in warm $\mathrm{H}_{2} \mathrm{SO}_{4}$ solution

Density $-99.7 \%$ of theoretical

Grain size-6 microns

Fig. 3.10-Microstructure of $\mathrm{UO}_{2.2} \cdot 3 \mathrm{Y}_{2} \mathrm{O}_{3}$ sintered in hydrogen for 12 hours at $1700^{\circ} \mathrm{C}$

Etched in warm $\mathrm{H}_{2} \mathrm{SO}_{4}$ solution

Density $-99.1 \%$ of theoretical

Grain size $-<3$ microns

Fig. 3.11 - Microstructure of $\mathrm{UO}_{2.2} \cdot 3 \mathrm{Y}_{2} \mathrm{O}_{3}$ sintered in hydrogen for 12 hours at $1700^{\circ} \mathrm{C}$ and then normalized in air for 60 hours at $1450^{\circ} \mathrm{C}$

Etched in warm $\mathrm{H}_{2} \mathrm{SO}_{4}$ solution

Density $-99.4 \%$ of theoretical

Grain size -3 mierons 
2. In a short time ( 19 hours) at $1850^{\circ} \mathrm{C}$ and above, a breakdown of the rhombohedral (Rh I) phase occurs; X-ray and microscopic examination showed two or more phases to be present. Figure 3.12 shows the microstructure of an as-sintered specimen. The formation of the second phase at $1850^{\circ} \mathrm{C}$ is shown in Figure 3.13. Figure 3.14 shows a sample after 11 hours at $1900^{\circ} \mathrm{C}$ treatment. As expected, the $\mathrm{BCC}$ phase concentration at $1900^{\circ} \mathrm{C}$ was greater than that at $1850^{\circ} \mathrm{C}$. Figure 3.15 shows the $\mathrm{BCC}$ phase formed on the outer surface of a specimen heated for 17 hours at $1900^{\circ} \mathrm{C}$.

Powder samples of $\mathrm{UO}_{2.99} \cdot 3 \mathrm{Y}_{2} \mathrm{O}_{3}$ were heated at $1650^{\circ}$ to $1700^{\circ} \mathrm{C}$ in air from 5 to 112 hours (Table 3.2). The X-ray analysis indicated trace amounts of a BCC phase present in these samples. Prior X-ray analysis indicated the powders were single-phase Rhombohedral I. Chemical analysis showed a decrease in the oxygen-to-uranium ratio from 2.99 to 2.92, but no measurable fuel loss in up to 112 hours at $1670^{\circ} \mathrm{C}$. The amount of BCC phase was higher, as would be expected, in samples which volatilized some fuel at $1700^{\circ} \mathrm{C}$. The phases observed were in agreement with the phase relationships presented in the section on the "UO $\mathrm{O}_{2}-\mathrm{UO}_{3}-\mathrm{Y}_{2} \mathrm{O}_{3}$ System."

TABLE 3.2

$\mathrm{X}$-RAY DIFFRACTION AND CHEMICAL ANALYSES OF $\mathrm{UO}_{2.99} \cdot 3 \mathrm{Y}_{2} \mathrm{O}_{3}$ POWDER AFTER VARIOUS HEAT TREATMENTS IN AIR

\begin{tabular}{|c|c|c|c|c|c|}
\hline \multirow[b]{2}{*}{ Temperature, ${ }^{\circ} \mathrm{C}$} & \multirow[b]{2}{*}{ Time, hr } & \multirow[b]{2}{*}{ Phases } & \multicolumn{2}{|c|}{ Chemical Analysis } & \multirow[b]{2}{*}{$\begin{array}{l}\text { Theoretical Percent Uranium } \\
\text { For } \mathrm{UO}_{2+\mathrm{x}^{3}} \mathrm{Y}_{2} \mathrm{O}_{3}{ }^{\mathrm{a}}\end{array}$} \\
\hline & & & Uranium, \% & $\begin{array}{c}\text { Oxygen-To-Uranium } \\
\text { Ratio }\end{array}$ & \\
\hline \multirow{3}{*}{1650} & 5 & Rh I & $24.7 \pm 0.1$ & 2. 98 & 24.7 \\
\hline & 25 & Rh I + Trace BCC & $24.7 \pm 0.1$ & 2. 97 & 24.7 \\
\hline & 47 & Rh I + Trace BCC & $24.7 \pm 0.1$ & 2. 97 & 24.7 \\
\hline \multirow[t]{2}{*}{1670} & 112 & Rh I + Slight trace & & & \\
\hline & & $\mathrm{BCC}$ & $24.7 \pm 0.1$ & 2. 97 & 24. 7 \\
\hline \multirow[t]{3}{*}{1700} & 20 & $\mathrm{Rh} \mathrm{I}+5 \% \mathrm{BCC}$ & - & - & $1-$ \\
\hline & 40 & $95 \% \mathrm{Rh} \mathrm{I}+5 \% \mathrm{BCC}$ & $24.3 \pm 0.1$ & 2. 94 & 24.7 \\
\hline & 60 & $95 \% \mathrm{Rh} \mathrm{I}+5 \% \mathrm{BCC}$ & $24.0 \pm 0.1$ & 2. 93 & 24.7 \\
\hline
\end{tabular}

${ }^{a}$ Where $\mathrm{x}=$ oxygen-to-uranium ratio minus 2.

Water Vapor Corrosion Studies

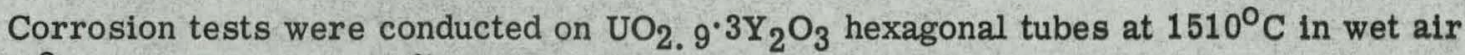
$\left(+20^{\circ} \mathrm{C}\right.$ dewpoint, 1.41 wt $\left.\% \mathrm{H}_{2} \mathrm{O}\right)$. After 100 hours a weight loss of less than 0.02 percent was observed. A control specimen heated in dry air $\left(-68^{\circ} \mathrm{C}\right.$ dewpoint) showed an increase in weight of 0.03 percent.

Water vapor corrosion tests were also conducted on $\mathrm{BeO}$ coextruded hexagonal tubes with a 0.076 millimeter $\left(0.003\right.$ inch) inside diameter cladding of $\mathrm{UO}_{2.9} \cdot 3 \mathrm{Y}_{2} \mathrm{O}_{3}$. These tests were performed by passing moist air through the tube which was radiantly heated by a tungsten heating element surrounding the outside surface of the tube. The temperature of the test sample was measured by Pt / Pt - 10Rh thermocouples embedded in the tube wall.

The mass velocity of the air for the tests was $4.37 \mathrm{~g} / \mathrm{sec}-\mathrm{cm}^{2}\left(0.0588 \mathrm{lb} / \mathrm{sec}-1 \mathrm{n} .{ }^{2}\right)$ with an inlet air temperature of $20^{\circ} \mathrm{C}$ and a water vapor content of 0.65 percent $\left(+7^{\circ} \mathrm{C}\right.$ dewpoint $)$ by weight. Tests were run continuously for 134 hours and 162 hours at $1370^{\circ} \mathrm{C}$.

The magnitude of material loss by water vapor corrosion was determined by waterimmersion measurement techniques. This method permits local cross sectional area change $s$ to be determined. These changes can then be directly converted into material loss data. 
Figure 3.12 and Figure 3.13 - These photomicrographs were transposed. The figure titles are correct as published.

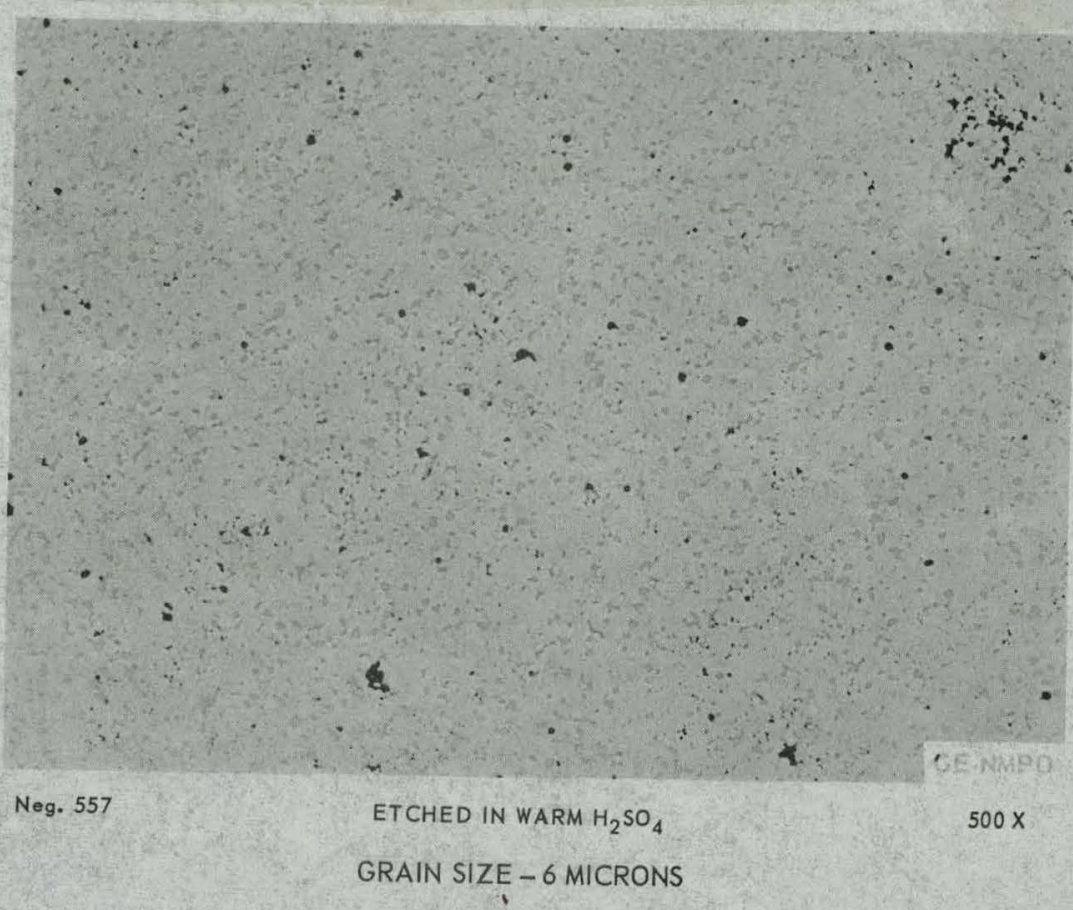

Fig. 3.12-Microstructure of $\mathrm{UO}_{2.9} \cdot 3 \mathrm{Y}_{2} \mathrm{O}_{3}$ sintered in oxygen for 3 hours at $1750^{\circ} \mathrm{C}$

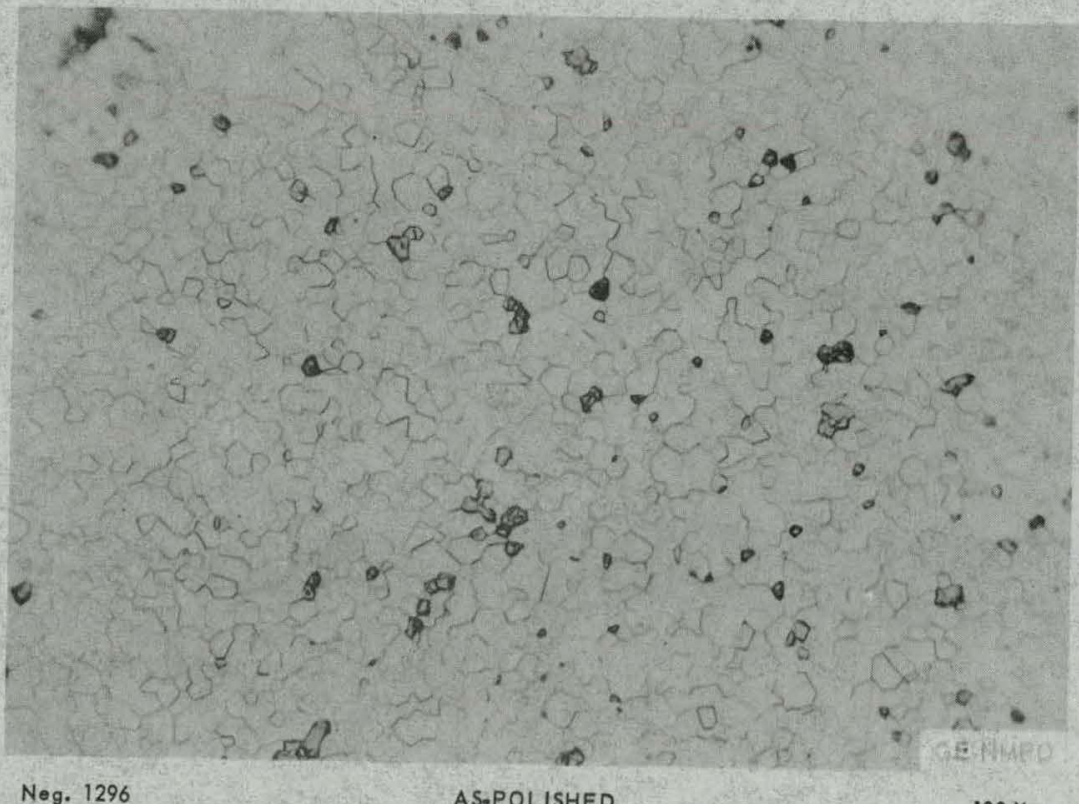

Fig. 3.13-Microstructure of oxygen-sintered $\mathrm{UO}_{2.9} \cdot 3 \mathrm{Y}_{2} \mathrm{O}_{3}$ after heating for 19 hours at $1850^{\circ} \mathrm{C}$ in oxygen 


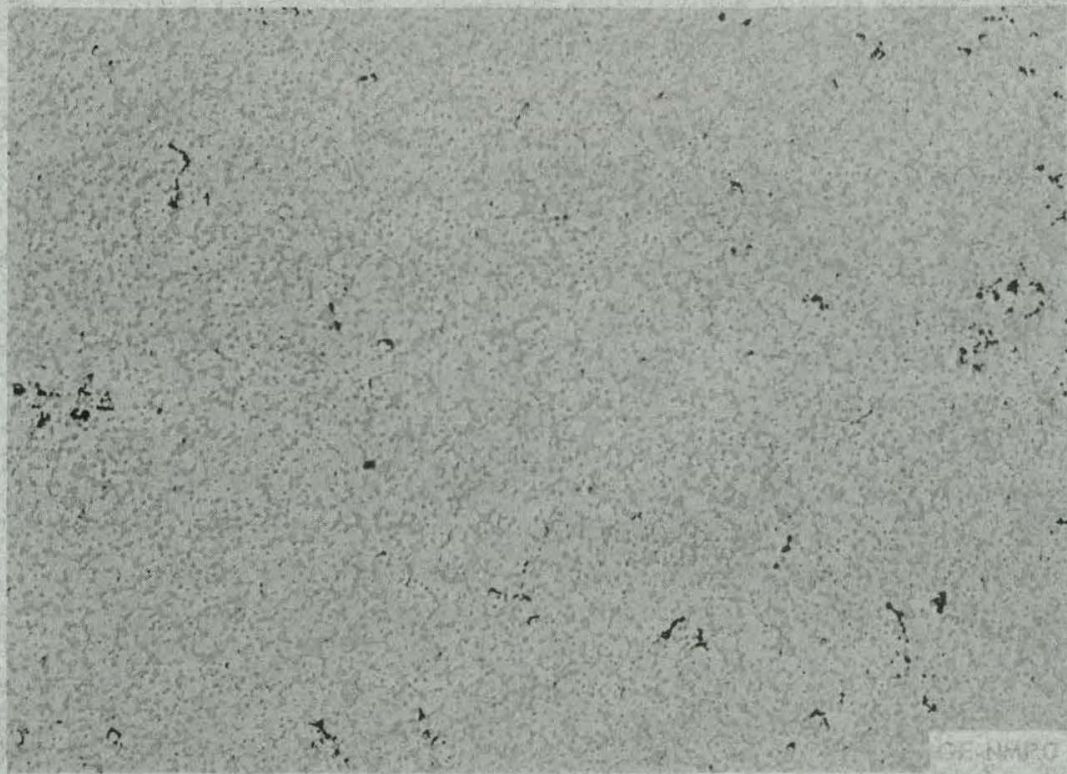

Neg. 1293

AS.POLISHED

$100 x$

Fig. 3.14 - Microstructure of oxygen-sintered $\mathrm{UO}_{2.9} \cdot 3 \mathrm{Y}_{2} \mathrm{O}_{3}$ after heating for 11 hours at $1900^{\circ} \mathrm{C}$ in oxygen

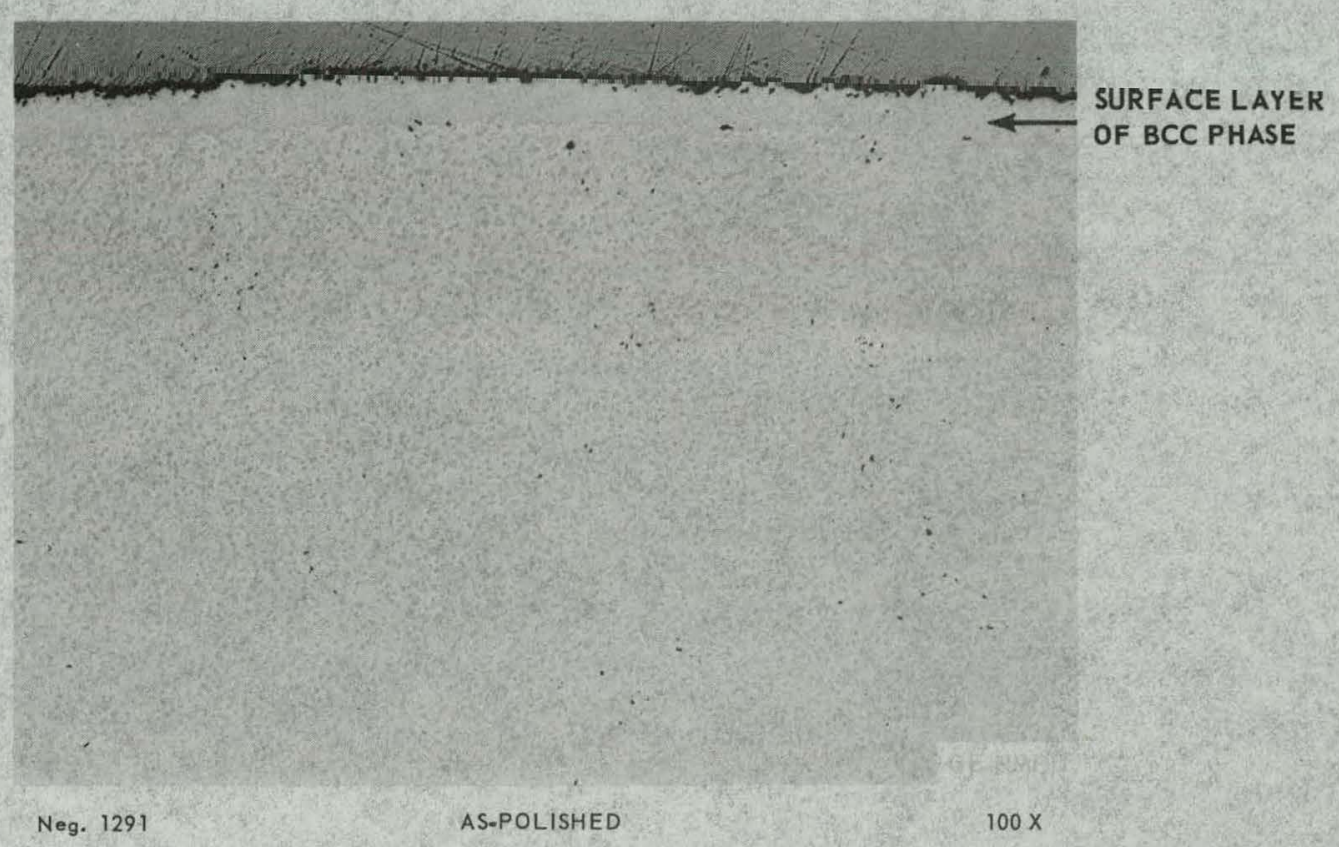

Fig. 3.15 - Microstructure of oxygen-sintered $\mathrm{UO}_{2.9} \cdot 3 \mathrm{Y}_{2} \mathrm{O}_{3}$ after heating for 17 hours at $1900^{\circ} \mathrm{C}$ in oxygen 
Previous experimental work ${ }^{18}$ on unfueled, uncoated $\mathrm{BeO}$ tubes showed these methods to be accurate within \pm 0.5 percent. The post-test measurement of tubes in this test showed no evidence of material loss. For comparison purposes, an uncoated $\mathrm{BeO}$ tube under the same conditions showed a cross sectional area reduction of 4.8 percent.

\section{Compatibility with $\mathrm{BeO}$}

Compatibility tests were conducted on $\mathrm{BeO}$ in contact with $\mathrm{UO}_{2.9} \cdot 3 \mathrm{Y}_{2} \mathrm{O}_{3}$ at temperatures above and below the $\mathrm{BeO}-\mathrm{Y}_{2} \mathrm{O}_{3}$ eutectic $\left(1580^{\circ} \mathrm{C}\right)$ utilizing $\mathrm{BeO}$ tubes coextruded with 0.076 millimeter $\left(0.003\right.$ inch) inside surface cladding of $\mathrm{UO}_{2.9} \cdot 3 \mathrm{Y}_{2} \mathrm{O}_{3}$ composition as well as pressed diffusion compacts.

Sintering studies on the coextruded tubes in an air atmosphere showed that a dense $\mathrm{UO}_{2.9}{ }^{\circ}$ $3 \mathrm{Y}_{2} \mathrm{O}_{3}$ cladding was formed at temperatures as low as $1550^{\circ} \mathrm{C}$; however, the $\mathrm{BeO}$ matrix did not densify well below $1580^{\circ} \mathrm{C}$. At temperatures above the $\mathrm{BeO}-\mathrm{Y}_{2} \mathrm{O}_{3}$ eutectic, a liquid grain boundary phase which promotes sintering forms in the BeO. However, the rate of liquid formation is very slow in an oxidizing atmosphere in the temperature range $1600^{\circ}$ to $1650^{\circ} \mathrm{C}$. At temperatures above $1650^{\circ} \mathrm{C}$, liquid formation is fairly rapid and is accompanied by deterioration of the cladding and significant fuel loss.

Figure 3.16 shows the microstructure of a specimen sintered in an oxidizing atmosphere for 3 hours at $1560^{\circ} \mathrm{C}$; the $\mathrm{BeO}$ grain size was 10 microns. During an additional 224 -hour test at $1560^{\circ} \mathrm{C}$, the $\mathrm{BeO}$ grain size increased to 90 microns with no evidence of liquid phase formation, as shown in Figure 3.17.

Figure 3.18 shows the microstructure of a specimen sintered in an oxidizing atmosphere for 2 hours at $1600^{\circ} \mathrm{C}$. A liquid phase was not detected, and the grain size of the $\mathrm{BeO}$ was approximately 20 microns. Continued heating for 16 hours resulted in slight liquid formation with grain size increasing to 42 microns. After a total of 82 hours at $1600^{\circ} \mathrm{C}$, a definite evidence of liquid formation at the $\mathrm{BeO}$ grain boundaries was noted, as shown in Figure 3.19, and the grain size increased to 68 microns.

After each of the above tests, no evidence of any cladding deterioration or breakdown of the cladding - substrate bond was found. The dark line at the interface of the photomicrographs is a result of the relief polishing of the cladding.

The addition of $\mathrm{ZrO}_{2}$ to $\mathrm{BeO}$ as a possible means of improving the refractoriness of the system was investigated. ${ }^{19}$ Interaction of the matrix and the cladding were studied in coextruded tubes in which 5 weight percent $\mathrm{ZrO}_{2}$ (as a sol) was added to the $\mathrm{BeO}$. Hightemperature stability tests were conducted to compare the compatibility between the cladding and to compare the $\mathrm{BeO}$ matrix of coextruded tubes with and without the $\mathrm{ZrO}_{2}$ addition. After sintering for 2 hours at $1600^{\circ} \mathrm{C}$, the grain size was 8 microns, as shown in Figure 3.20 compared to 20 microns for a sample without the $\mathrm{ZrO}_{2}$ addition (Figure 3.18). After 82 hours at $1600^{\circ} \mathrm{C}$ in dry air, grain size increased to 20 microns (Figure 3.21), compared to 68 microns for specimens without $\mathrm{ZrO}_{2}$ addition heated under the same conditions, Figure 3.19. Petrographic examination showed the presence of cubic $\mathrm{ZrO}_{2}$, an indication that a portion of the $\mathrm{Y}_{2} \mathrm{O}_{3}$ was combining with the monoclinic $\mathrm{ZrO}_{2}$. There was also evidence of a liquid phase, assumed to be $\mathrm{BeO}-\mathrm{Y}_{2} \mathrm{O}_{3}$.

Analysis of coextruded tubes having $\mathrm{UO}_{2.9} \cdot 3 \mathrm{Y}_{2} \mathrm{O}_{3}$ as cladding on $\mathrm{BeO}$ with and without a 5 weight percent $\mathrm{ZrO}_{2}$ addition was made utilizing the electron probe to identify phases present in the cladding and matrix. The cladding of the $\mathrm{BeO}$ tube without the $\mathrm{ZrO}_{2}$ addition was single phase, analyzing 25 percent uranium and 55 percent yttrium, which corresponds to the $\mathrm{UO}_{2.9} \cdot 3 \mathrm{Y}_{2} \mathrm{O}_{3}$ composition. The grain boundary phase in the $\mathrm{BeO}$ was a $\mathrm{BeO}-$ $\mathrm{Y}_{2} \mathrm{O}_{3}$ composition containing 40 to 45 percent yttrium. No uranium was detected in the Beó. 


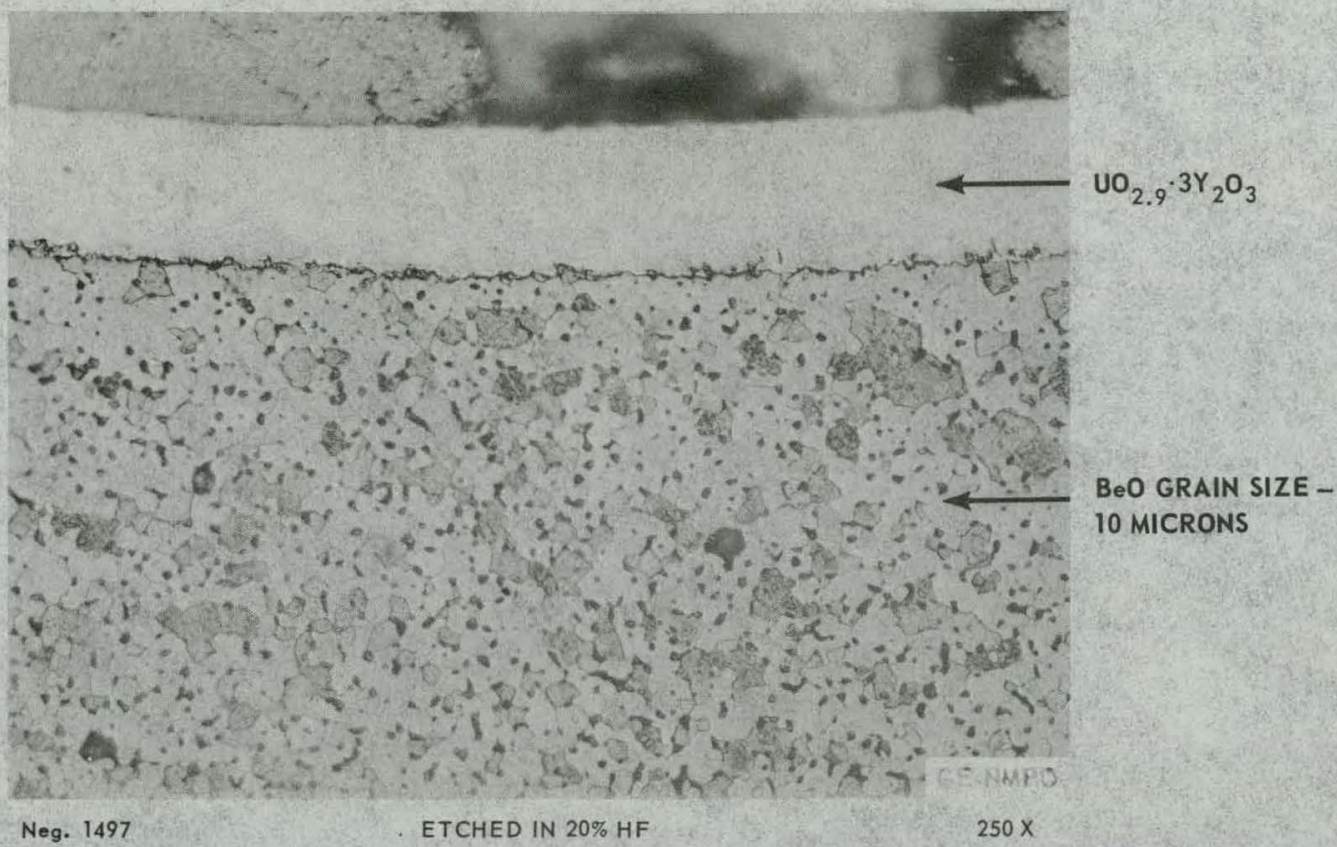

Fig. 3.16-Microstructure of coextruded $\mathrm{UO}_{2.9} \cdot 3 \mathrm{Y}_{2} \mathrm{O}_{3}-\mathrm{BeO}$ tube sintered at $1560^{\circ} \mathrm{C}$ for 3 hours in air

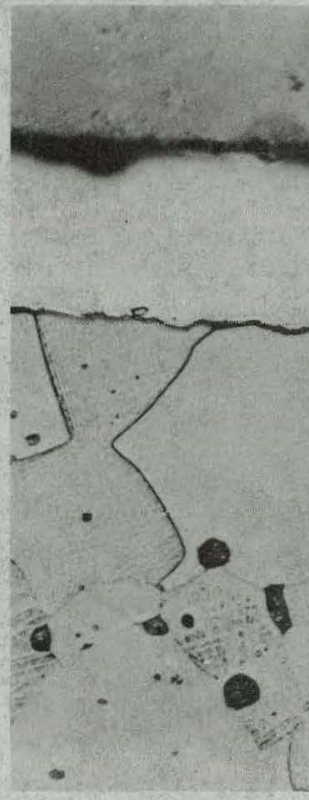

Neg. 1500
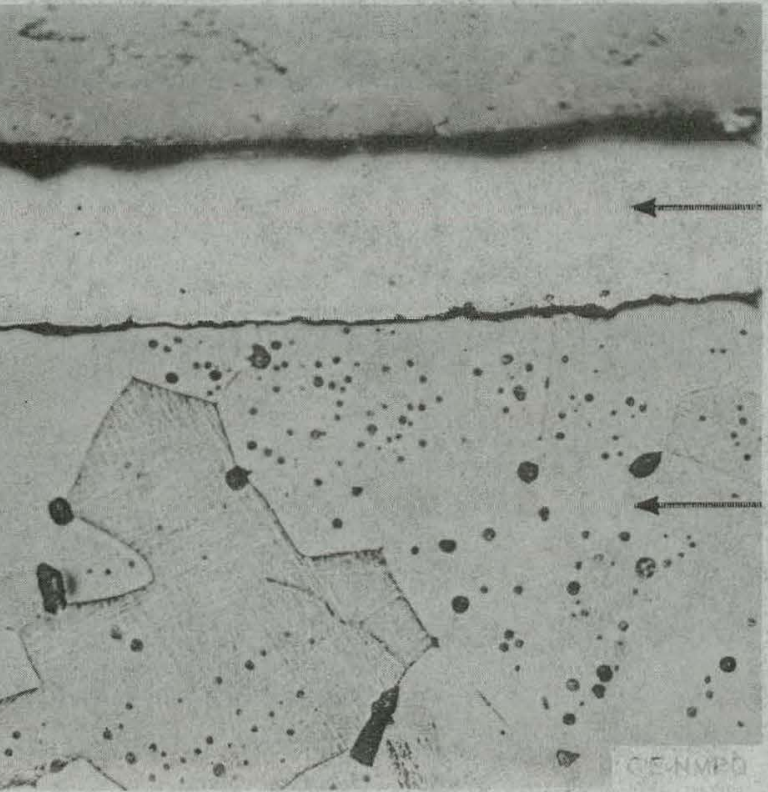

ETCHED IN $20 \%$ HF

Fig. 3.17-Microstructure of coextruded $\mathrm{UO}_{2.9} \cdot 3 \mathrm{Y}_{2} \mathrm{O}_{3}-\mathrm{BeO}$ tube siatered at $1560^{\circ} \mathrm{C}$ for 3 hours in air and heated for 224 hours at $1560^{\circ} \mathrm{C}$ in dry air uo $2.3_{2} \cdot \mathrm{Y}_{2} \mathrm{O}_{3}$

BeO GRAIN SIZE -

90 MICRONS 


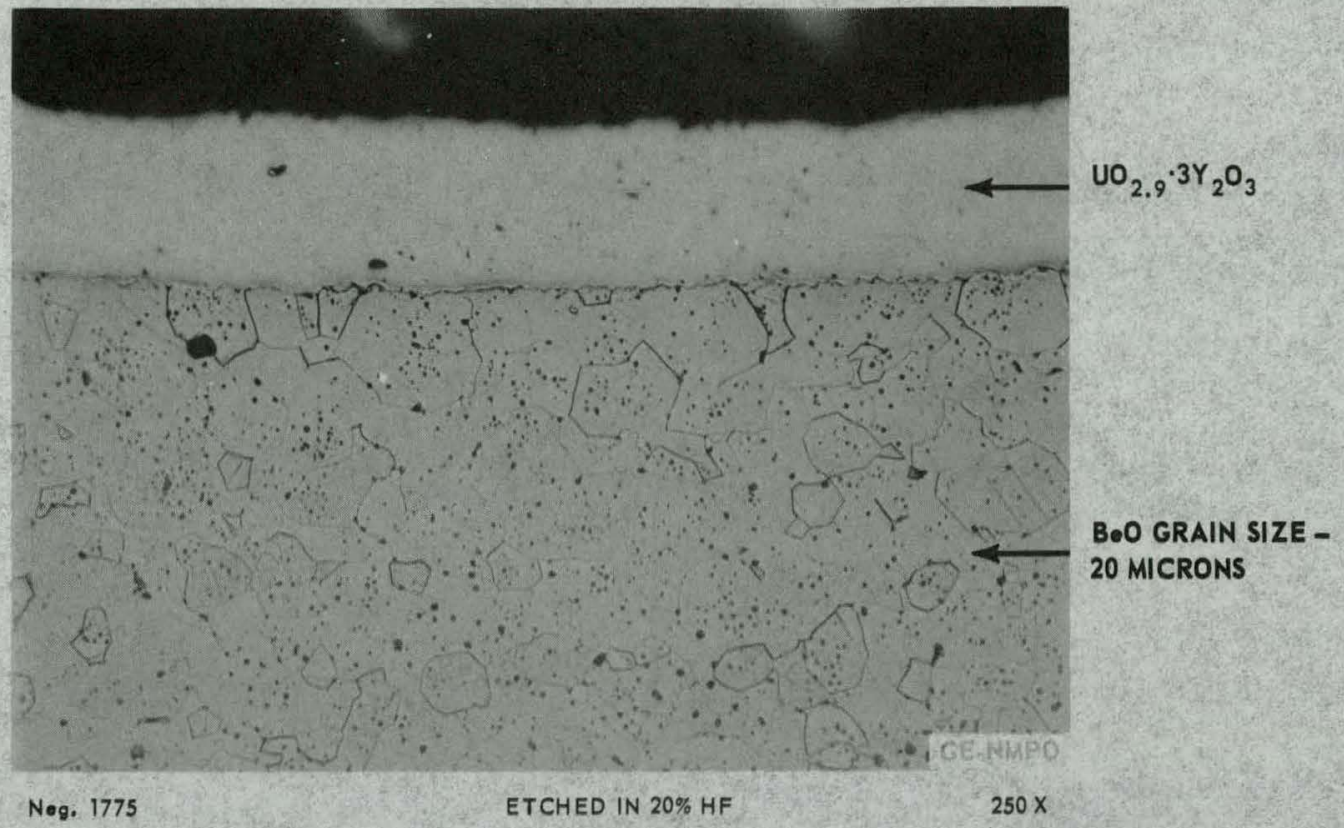

Fig. 3.18-Microstructure of coextruded $\mathrm{UO}_{2.9} \cdot 3 \mathrm{Y}_{2} \mathrm{O}_{3}-\mathrm{BeO}$ tube sintered in air for 2 hours at $1600^{\circ} \mathrm{C}$

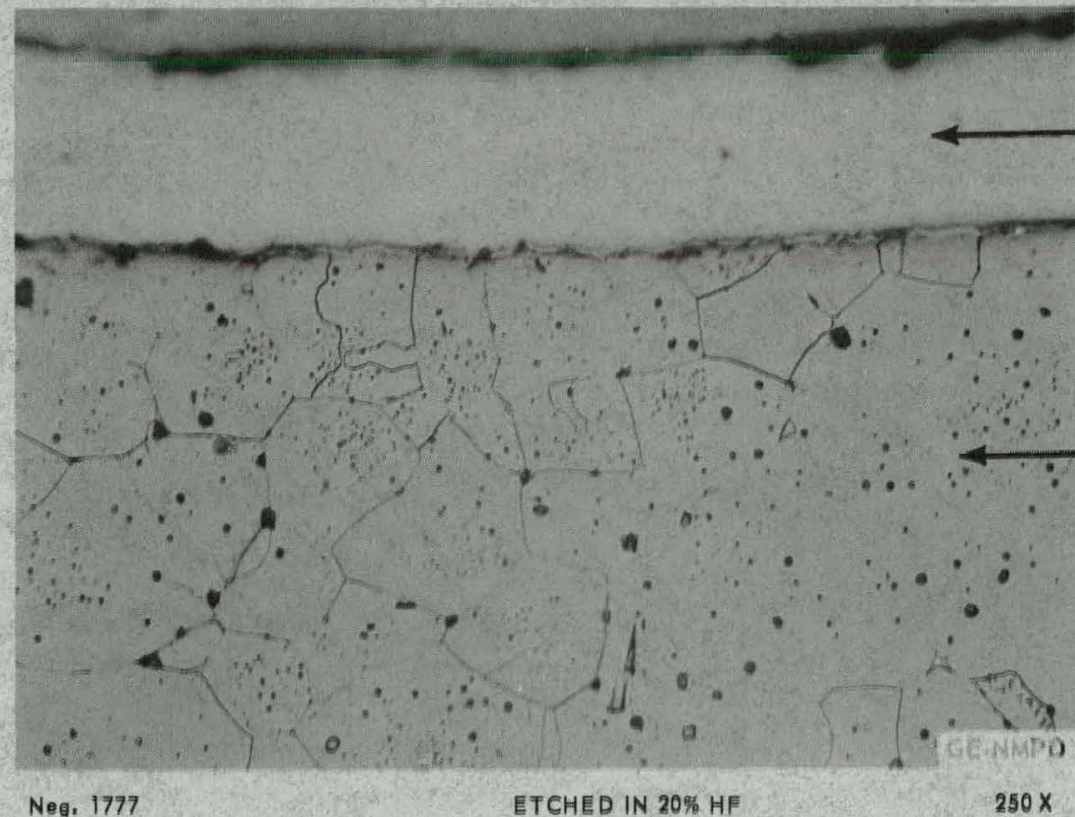

Fig. 3.19 - Mierostrueture of eoextruded $\mathrm{UO}_{2,9} \cdot 3 \mathrm{Y}_{2} \mathrm{O}_{\mathrm{g}}=\mathrm{BeO}$ tube sintered In air for 2 hours at $1600^{\circ} \mathrm{C}$ and heated in dry air for 82 hours at $1600^{\circ} \mathrm{C}$ 


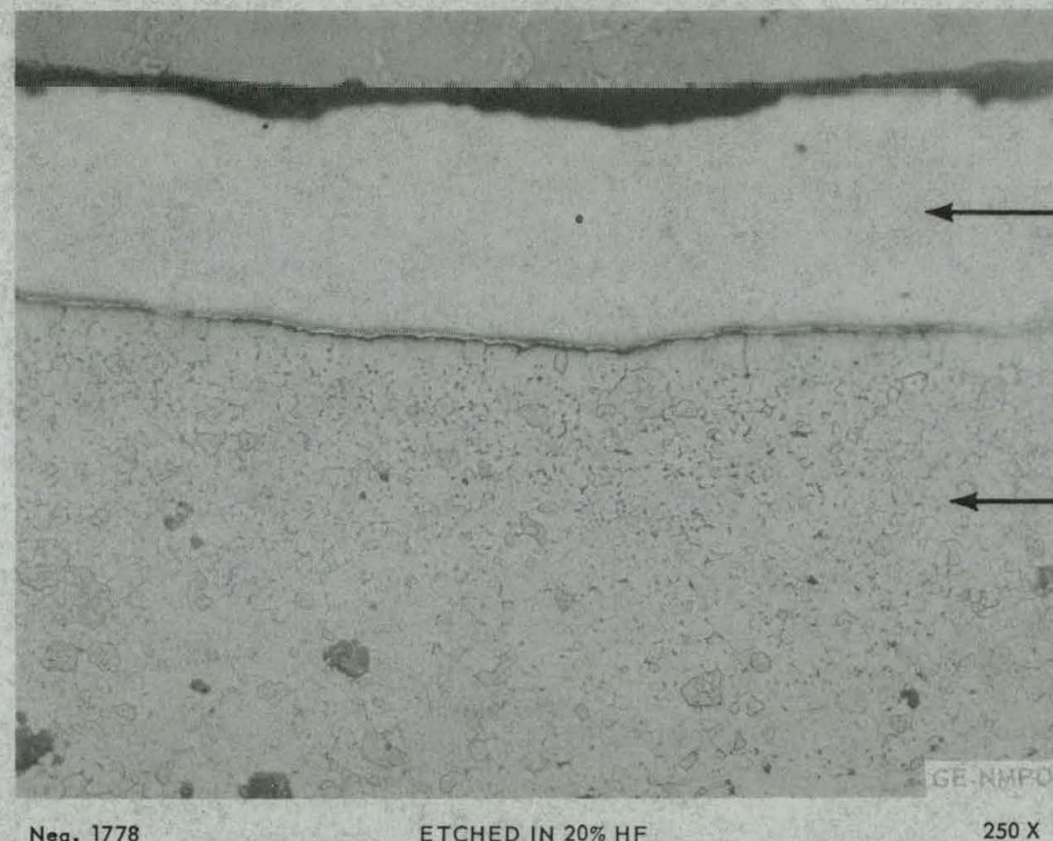

$\mathrm{UO}_{2.9} \cdot 3 \mathrm{Y}_{2} \mathrm{O}_{3}$

Fig. 3.20-Microstructure of coextruded $\mathrm{UO}_{2.9} \cdot 3 \mathrm{Y}_{2} \mathrm{O}_{3}-\mathrm{BeO}+5$ weight percent $\mathrm{ZrO}_{2}$ tube sintered in air for 2 hours at $1600^{\circ} \mathrm{C}$

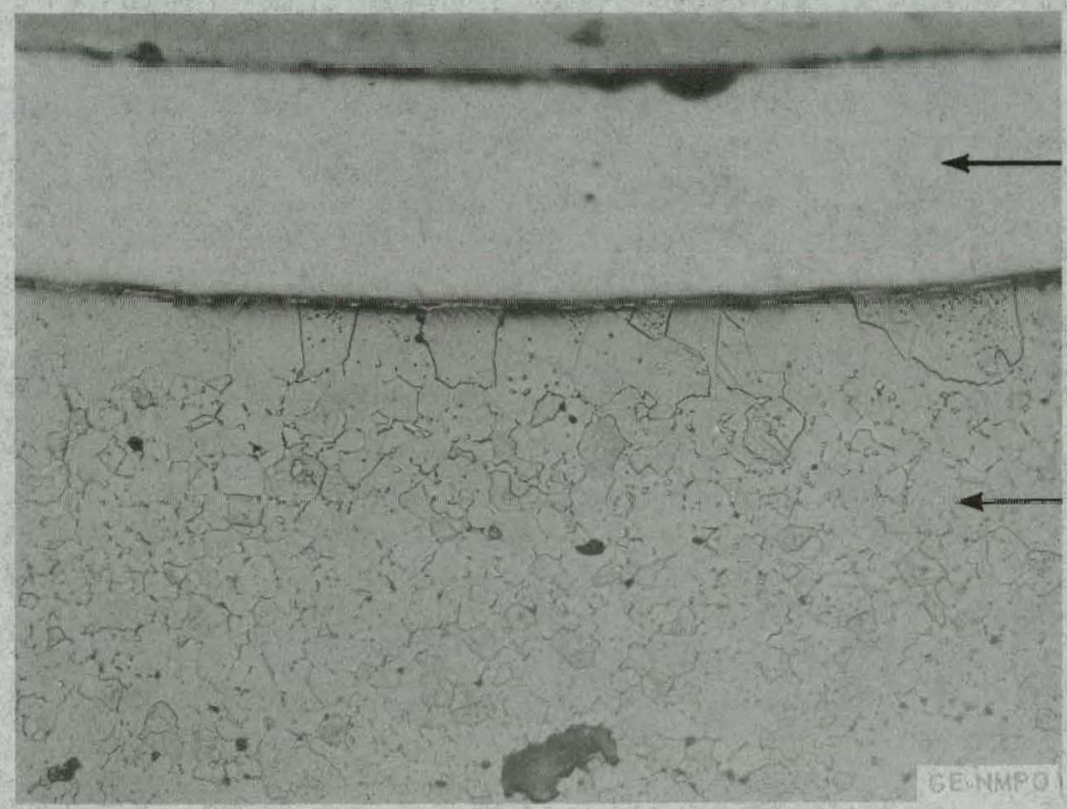

$\mathrm{UO}_{2.9} \cdot 3 \mathrm{Y}_{2} \mathrm{O}_{3}$

Neg. 1780

Fig. 3.21-Microstructure of coextruded $\mathrm{UO}_{2.9} \cdot 3 \mathrm{Y}_{2} \mathrm{O}_{3}-\mathrm{BeO}+5$ weight percent $\mathrm{ZrO}_{2}$ tube sintered in air for 2 hours at $1600^{\circ} \mathrm{C}$ and heated in dry air for 82 hours at $1600^{\circ} \mathrm{C}$ 
Electron-probe analysis of clad tubes with the addition of 5 weight percent $\mathrm{ZrO}_{2}$ to the $\mathrm{BeO}$ indicated a yttria-deficient zone in the cladding next to the $\mathrm{BeO}$. The composition was 45 percent uranium and 49 percent yttrium, corresponding to $2 \mathrm{UO}_{2}+\mathrm{x} \cdot 3 \mathrm{Y}_{2} \mathrm{O}_{3}$, whereas the balance of the cladding was the normal $\mathrm{UO}_{2.9} \cdot 3 \mathrm{Y}_{2} \mathrm{O}_{3}$ composition. As previously observed, yttria was present in the $\mathrm{BeO}$ both as a $\mathrm{BeO}-\mathrm{Y}_{2} \mathrm{O}_{3}$ grain boundary phase and in solid solution with the $\mathrm{ZrO}_{2}$. However, the small area of the $\mathrm{Y}_{2} \mathrm{O}_{3}-\mathrm{BeO}$ grain boundary phase was less than the limit of resolution of the electron beam, and therefore a quantitative analysis of the yttria-containing phases was not possible. No urania was detected in the BeO.

Hexagonal BeO tubes, 0.671 centimeter ( 0.264 inch) across flats, were prepard with 0.076 millimeter $\left(0.003\right.$ inch) of $\mathrm{UO}_{2.9} \cdot 3 \mathrm{Y}_{2} \mathrm{O}_{3}$ coextruded on the bore which was, in turn, dip coated with 0.051 millimeter $(0.002$ inch) of BeO to obtain an $\mathrm{D}$ of 0.450 centimeter (0.185 inch). An as-sintered tube is shown in Figure 3.22. These tubes were bench tested in moving dry air at $1370^{\circ} \mathrm{C}$ for 979 hours to provide reference data for future in-pile testing at the same temperature. The tubes remained unchanged except for a slight grain growth as shown in Figure 3.23. The tubes showed no weight loss during testing.

\section{Fuel Recovery}

Since fuel reprocessing is of concern in any reactor system, a cursory evaluation of fuel reclamation was made as a feasibility study on a laboratory scale only. These preliminary studies showed that the $\mathrm{UO}_{2.9} \cdot 3 \mathrm{Y}_{2} \mathrm{O}_{3}$ cladding on the $\mathrm{BeO}$ fuel element has the further advantage over a dispersed-type fuel element in that the recovery and reprocessing of the fuel is greatly simplified. The fueled cladding can be removed from the $\mathrm{BeO}$ tube in 2 to 3 hours using warm perchloric acid resulting in a solution containing all of the fuel.

\section{Thermal Expansion}

The thermal expansion of the $\mathrm{UO}_{2+\mathrm{x}} \cdot 3 \mathrm{Y}_{2} \mathrm{O}_{3}$ composition in both the oxidized and reduced form was measured using a cantilevered-beam, continuous-recording technique. Figure 3.24 is a plot of the percent of expansion as a function of temperature for $\mathrm{UO}_{2 .} \cdot 3 \mathrm{Y}_{2} \mathrm{O}_{3}$ measured in air. The thermal expansion curve for $\mathrm{BeO}^{18}$ is also plotted in Figure 3.24 to illustrate the good match in the thermal expansion characteristics of $\mathrm{BeO}$ and $\mathrm{UO}_{2} .9 \cdot 3 \mathrm{Y}_{2} \mathrm{O}_{3}$. The cantilever-beam technique was used to observe dimensional changes of hydrogen-sintered specimens $\left(\mathrm{UO}_{2} \cdot 2^{\cdot} \cdot 3 \mathrm{Y}_{2} \mathrm{O}_{3}\right)$ during heating from $25^{\circ}$ to $1200^{\circ} \mathrm{C}$ and $1425^{\circ} \mathrm{C}$ in air. Figure 3.25 shows the dimensional changes that dense bodies of the $\mathrm{UO}_{2.2} \cdot 3 \mathrm{Y}_{2} \mathrm{O}_{3}$ composition undergo when heated in air. Table 3.3 summarizes the $\mathrm{X}$-ray data for phase transitions which occurred during these experiments. The sample heated to $1200^{\circ} \mathrm{C}$ contracted more than the one heated to $1425^{\circ} \mathrm{C}$. This is in agreement with calculated unit cell volumes for the phases present.

The sample heated to $1200^{\circ} \mathrm{C}$ had an oxygen-to-uranium ratio of 2. 88 , and the sample heated to $1425^{\circ} \mathrm{C}$ had an oxygen-to-uranium ratio of 2.90 . Thus, the inflection in the expansion curve for the $1425^{\circ} \mathrm{C}$ sample above $1200^{\circ} \mathrm{C}$ primarily reflects cation rearrangement since the sample is almost fully oxidized by $1200^{\circ} \mathrm{C}$.

The linear thermal expansion of the $\mathrm{UO}_{2+\mathrm{x}} \cdot 3 \mathrm{Y}_{2} \mathrm{O}_{3}$ composition was measured at temperatures up to $2300^{\circ} \mathrm{C}$ in hydrogen by optical methods. The specimen was $\mathrm{UO}_{2.92} \cdot 3 \mathrm{Y}_{2} \mathrm{O}_{3}$ at the beginning of the test. The resulting curve, Figure 3.26, consists of two distinct regions with an inflection between $1200^{\circ} \mathrm{C}$ and $1500^{\circ} \mathrm{C}$. Since the original specimen has an oxidized, single-phase rhombohedral I structure and the reduced specimen after treatment in hydrogen above $2000^{\circ} \mathrm{C}$ consists of two phases, BCC and FCC, these data suggest that transformation occurs in the $1200^{\circ}$ to $1500^{\circ} \mathrm{C}$ region. The heating portion of the curve above $1500^{\circ} \mathrm{C}$ and the cooling curve show the expansion characteristics of the body in the 


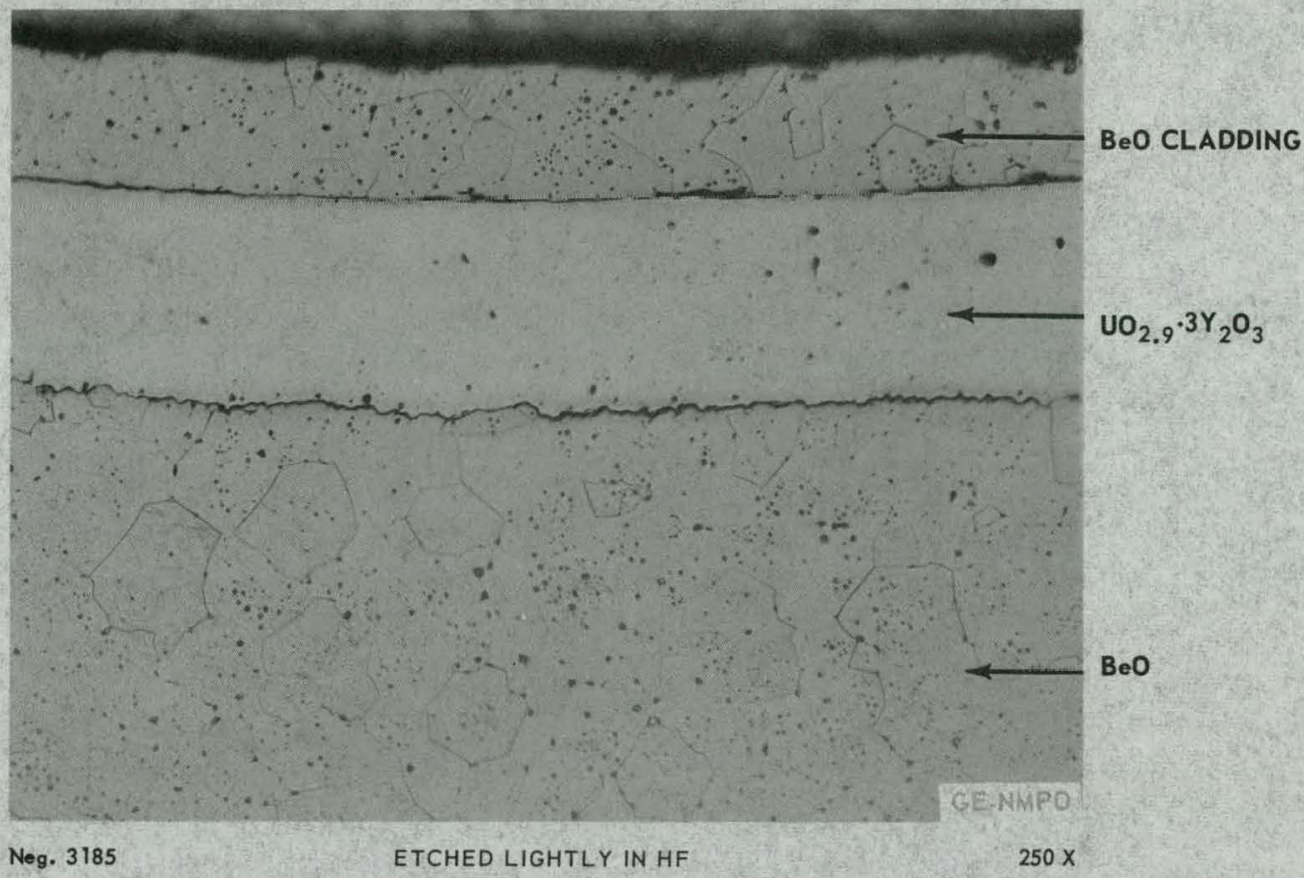

Fig. 3.22 - Coextruded $\mathrm{BeO}-\mathrm{UO}_{2.9} \cdot 3 \mathrm{Y}_{2} \mathrm{O}_{3}$ tube dip coated with $\mathrm{BeO}$ cladding and sintered for 2 hours at $1600^{\circ} \mathrm{C}$ in air

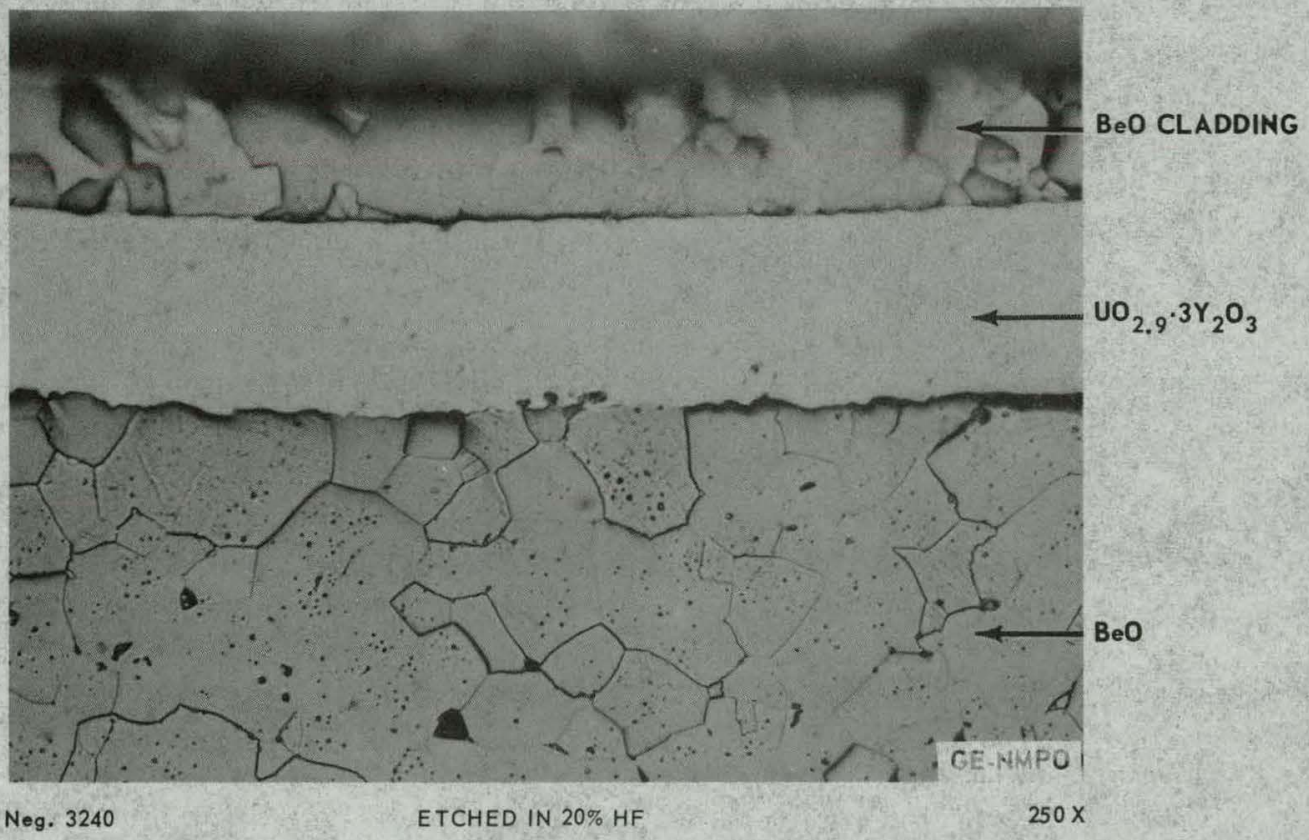

Fig. 3.23-Coextruded dip coated $\mathrm{BeO}-\mathrm{UO}_{2.9} \cdot 3 \mathrm{Y}_{2} \mathrm{O}_{3}$ tube sintered for 2 hours at $1600^{\circ} \mathrm{C}$ in air and lieated for 979 hours in dry air at $1370^{\circ} \mathrm{C}$ 


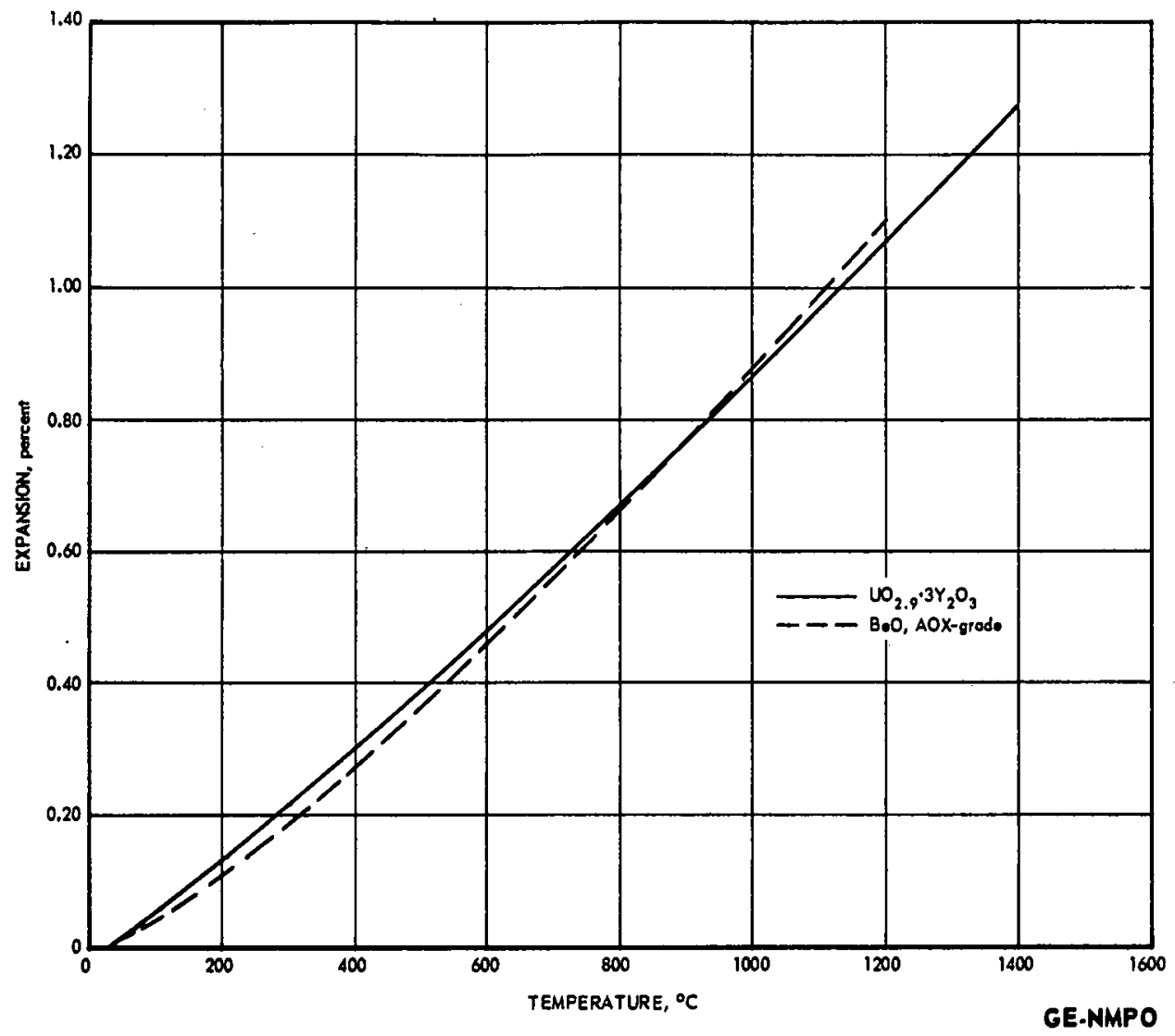

Fig. 3.24 - Thermal expansion of $\mathrm{BeO}$ and $\mathrm{UO}_{2.9} \cdot 3 \mathrm{Y}_{2} \mathrm{O}_{3}$ in air

TABLE 3.3

PHABE CHANGE OF REDUCED UO $2.2,3 \mathrm{Y}_{2} \mathrm{O}_{3}$ THERMAL

EXPANSION SPECIMENS HEATED IN AIR FROM $25^{\circ} \mathrm{C}$ TO $1425^{\circ} \mathrm{C}$

\begin{tabular}{ccl}
\hline $\begin{array}{c}\text { Temperature, } \\
{ }_{\mathrm{C}}\end{array}$ & $\begin{array}{c}\text { Oxidation } \\
\text { State }\end{array}$ & \multicolumn{1}{c}{ Phase } \\
\hline 25 & Roduced & $\begin{array}{l}\text { Rhombohedral I (Reduced) }+ \\
\text { Body-centered cubic (BCC) }\end{array}$ \\
1200 & Oxidized & Rhombohedral I1 + BCC \\
1425 & Oxidized & Rhombohedral I (Oxidized) \\
\hline
\end{tabular}

The rhombohedral If has has been observed as an intermedlate compound found during the oxidation of $2 \mathrm{UO}_{2}, 2 \cdot 3 \mathrm{Y}_{2} \mathrm{O}_{3}$. 


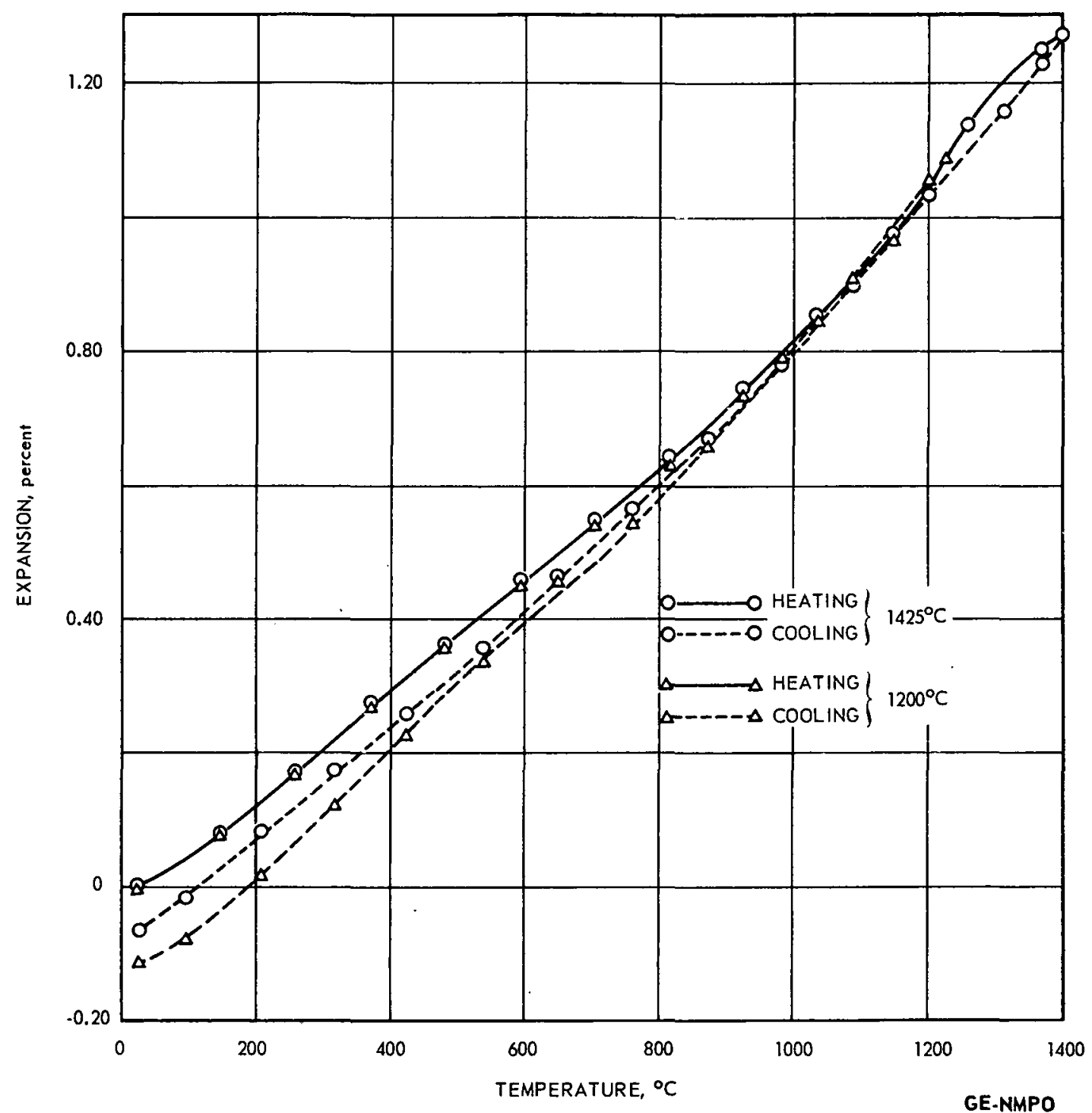

Fig. 3.25 - Thermal expansion curves for hydrogen-sintered samples measured in air to $1200^{\circ} \mathrm{C}$ and $1425^{\circ} \mathrm{C}$

diphasic, reduced state. Chemical analysis of the specimen after test showed the oxygento-uranium ratio was 2.08. Electron probe analysis established that the composition of the $\mathrm{BCC}$ phase was $\mathrm{UO}_{2+\mathrm{x}} \cdot 6 \mathrm{Y}_{2} \mathrm{O}_{3}$ and that of the $\mathrm{FCC}$ phase was $\mathrm{UO}_{2+\mathrm{x}} \cdot \mathrm{Y}_{2} \mathrm{O}_{3}$.

Figure 3.27 shows the thermal expansion as a function of temperature for a reduced $\mathrm{UO}_{2}+\mathrm{x} \cdot 3 \mathrm{Y}_{2} \mathrm{O}_{3}$ sample measured in hydrogen to $2300^{\circ} \mathrm{C}$. Included for comparison purposes are thermal expansion curves for $\mathrm{UO}_{2}$ and $\mathrm{Y}_{2} \mathrm{O}_{3}$ obtained under the same experimental conditions.

\section{Thermal Conductivity}

The thermal conductivity of the $\mathrm{UO}_{2+\mathrm{x}}{ }^{\circ} 3 \mathrm{Y}_{2} \mathrm{O}_{3}$ composition was measured between $750^{\circ}$ and $1950^{\circ} \mathrm{C}$ in hydrogen. The measurements were made by using the radial heat flow technique on hydrogen-sintered $\mathrm{UO}_{2.2} \cdot 3 \mathrm{Y}_{2} \mathrm{O}_{3}$ specimens of 51 -centimeter (2-inch) diameter discs, 1.3 centimeters $(1 / 2-1$ nch $)$ thick, having a density of 99.5 percent of theoretical. Figure 3.28 is a plot of the thermal conductivity versus mean temperature of these speci- 


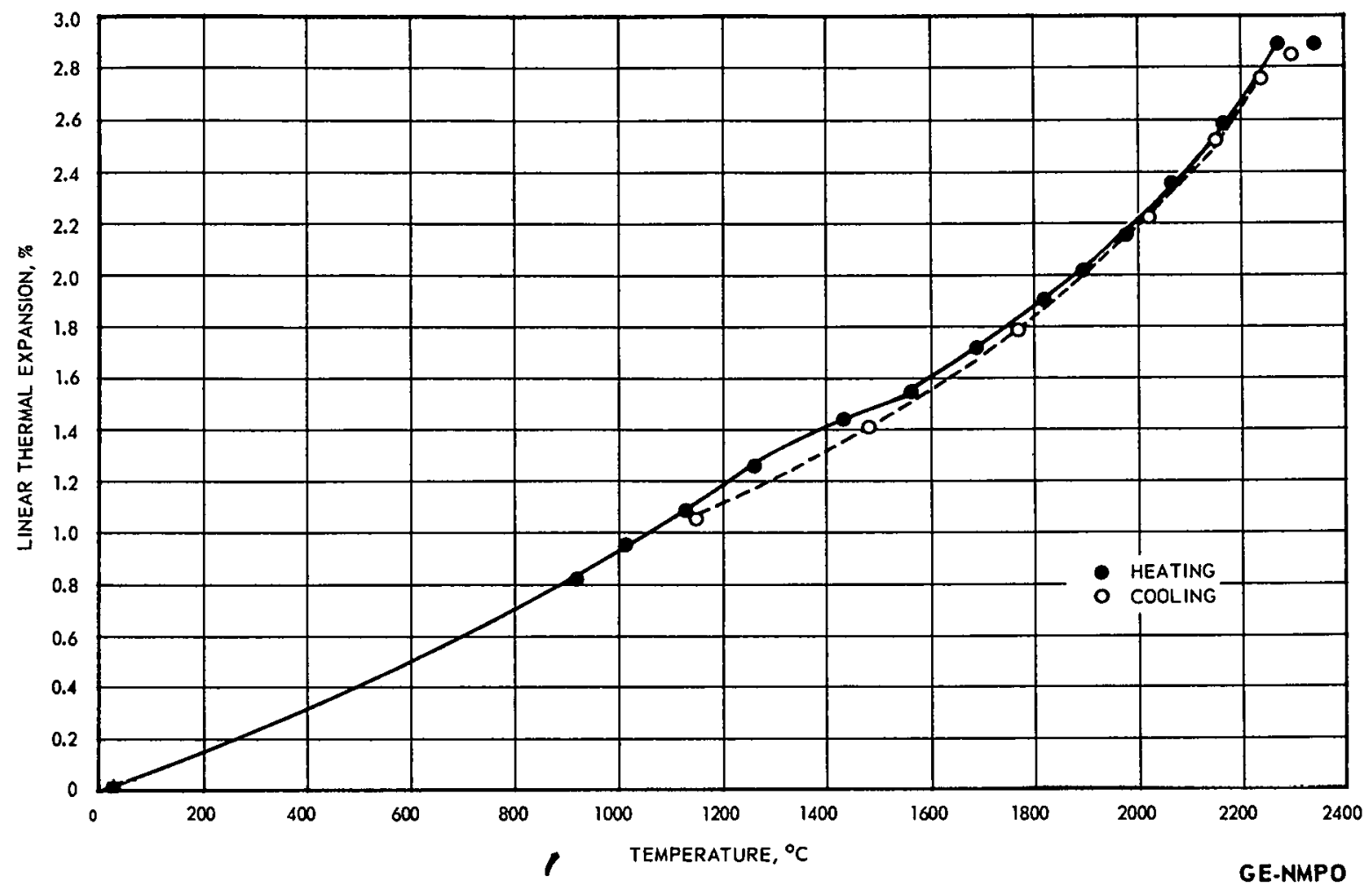

Fig. 3.26 - Linear thermal expansion of oxygen-sintered sample measured in hydrogen to $2300^{\circ} \mathrm{C}$

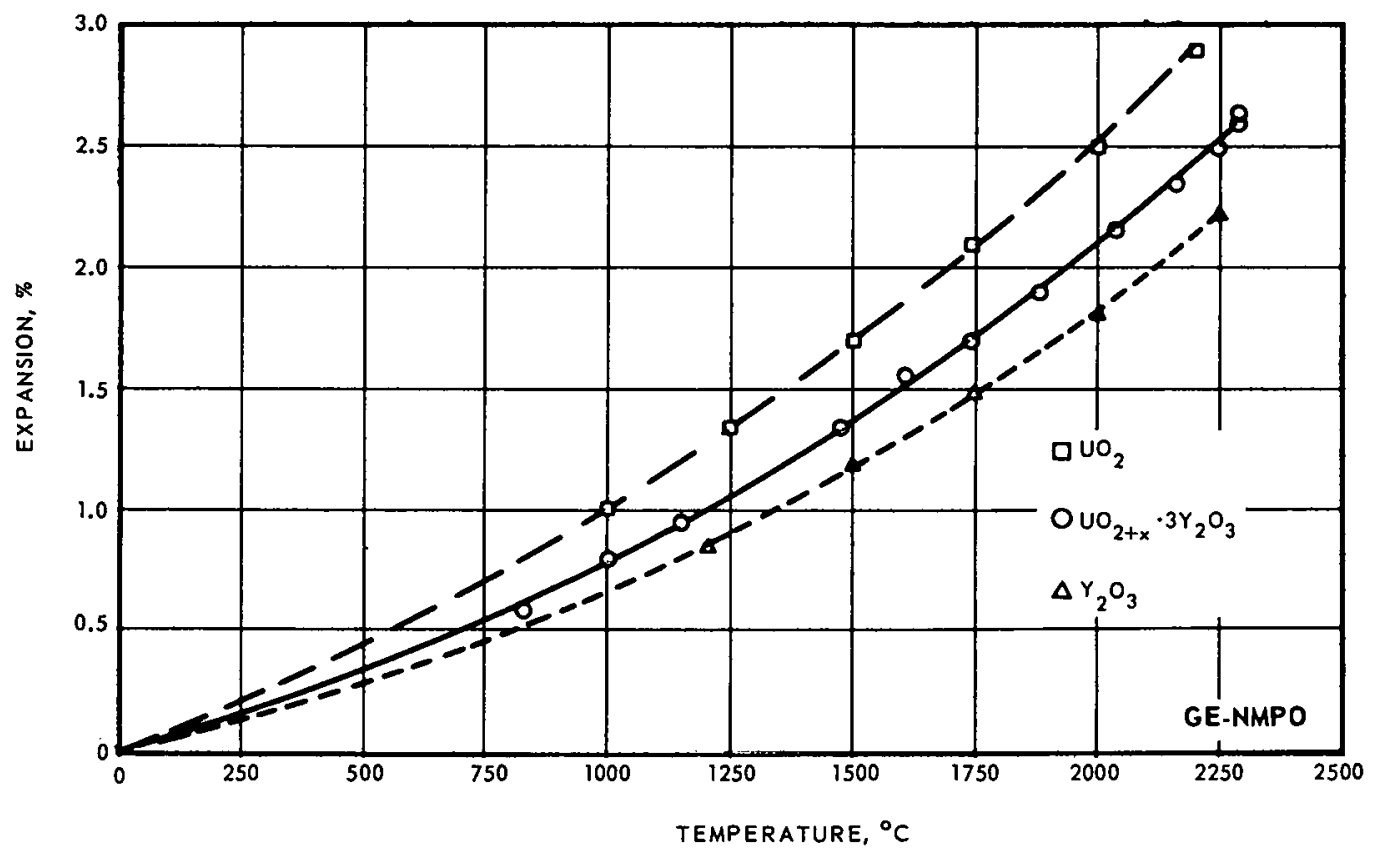

Fig. 3.27 - Thermal expansion of reduced $\mathrm{UO}_{2+\mathrm{x}} \cdot 3 \mathrm{Y}_{2} \mathrm{O}_{3}, \mathrm{UO}_{2}$, and $\mathrm{Y}_{2} \mathrm{O}_{3}$ measured in hydrogen 


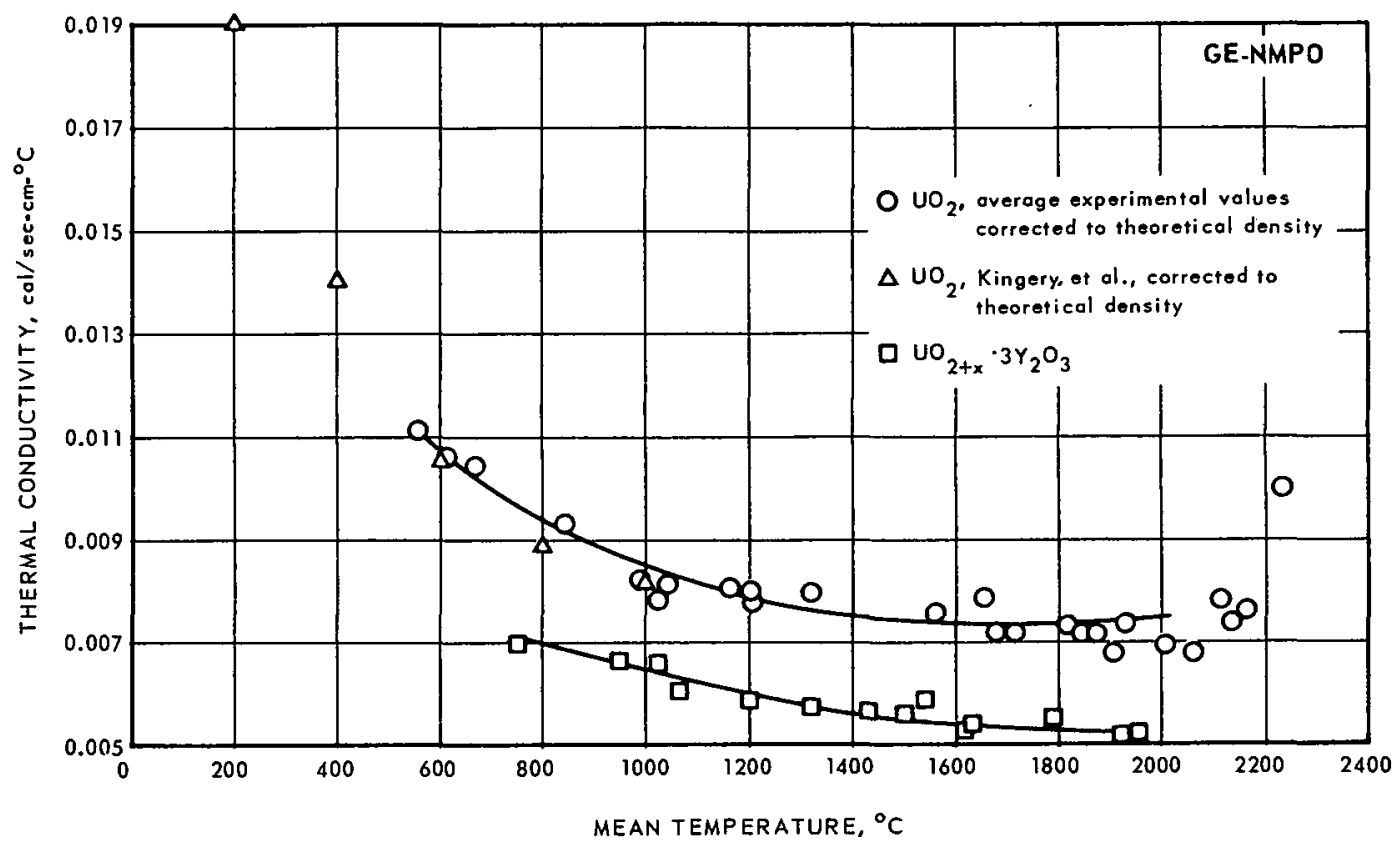

Fig. 3.28 - Thermal conductivity versus mean temperature for $\mathrm{UO}_{2+\mathrm{x}} \cdot 3 \mathrm{Y}_{2} \mathrm{O}_{3}$ and $\mathrm{UO}_{2}$

mens. The thermal conductivity (K) varied from $0.0069 \mathrm{cal} / \mathrm{sec}-\mathrm{cm}-{ }^{\circ} \mathrm{C}$ at a mean temperature of $750^{\circ} \mathrm{C}$ to 0.0052 at $1950^{\circ} \mathrm{C}$. The thermal conductivity for $\mathrm{UO}_{2} .01$ was measured to $2200^{\circ} \mathrm{C}$, and these data in addition to Kingery, et al. , 20 are included here for comparison.

Densities

The theoretical densities of the $\mathrm{UO}_{2+\mathrm{x}} \cdot 3 \mathrm{Y}_{2} \mathrm{O}_{3}$ composition were determined from X-ray data for both the oxidized state $\left(\mathrm{UO}_{2} .9 \cdot 3 \mathrm{Y}_{2} \mathrm{O}_{3}-\mathrm{Rh}\right.$ I phase) and the reduced state $\left(\mathrm{UO}_{2 .} \cdot 3 \mathrm{Y}_{2} \mathrm{O}_{3}-28 \% \mathrm{Rh} \mathrm{I}\right.$ and $72 \%$ FCC phases). The values are $6.00 \mathrm{gm} / \mathrm{cm}^{3}$ and 5.867 $\mathrm{gm} / \mathrm{cm}^{3}$, respectively.

\section{Electrical Properties}

Measurements of the electrical resistivity of the $\mathrm{UO}_{2+\mathrm{x}} \cdot 3 \mathrm{Y}_{2} \mathrm{O}_{3}$ composition were made on both oxidized (oxygen-sintered) and reduced (hydrogen-sintered) specimens in a helium atmosphere. Resistivity was calculated from the measured voltage drop across a specicarrying a 60-cycle a-c current.

The experimental results are plotted in Figure 3.29. The data indicate that the oxidized material has a higher resistivity than the reduced material for temperatures below $1700^{\circ} \mathrm{C}$. However, at higher temperatures, appreciable reduction of the oxidized material occurs by evolution of oxygen which is swept away by the helium atmosphere. Under these circumstances, the resistivity of the oxidized specimen approaches that of the reduced material. Chemical analysis confirms the reduction of the oxidized specimen, showing a decrease in the oxygen-to-uranium ratio from 2.92 to 2.18 . The resistivity of both samples at $2200^{\circ} \mathrm{C}$ was $0.55 \mathrm{ohm}-\mathrm{cm}$.

A cell was constructed to measure the electrical conductivity and to determine the conduction mechanism for various compositions in the $\mathrm{UO}_{2}-\mathrm{UO}_{3}-\mathrm{Y}_{2} \mathrm{O}_{3}$ system in an oxidizing atmosphere. A schematic diagram of the cell is shown in Figure 3.30. The charge-carrying species in a conductor may be identified as ionic by means of electrolytic cell measuremeil. A simple method consists of using the material under study as a solid electrolyte 
to separate two electrode reactions. For an oxide, a cell of the type $\mathrm{O}_{2}(\mathrm{P})$, Pt: MO: Pt, $\mathrm{O}_{2}\left(P^{\prime}\right)$ may be used, where $P$ and $P^{\prime}$ refer to different partial pressures of oxygen maintained at the respective electrodes. If the oxide (MO) is an ionic conductor, the potential developed will be that shown in Equation (3.1):

$$
E_{\mathrm{i}}=\frac{2.3 R T}{4 F} \log \frac{\mathrm{P}^{n}}{\mathrm{P}}
$$

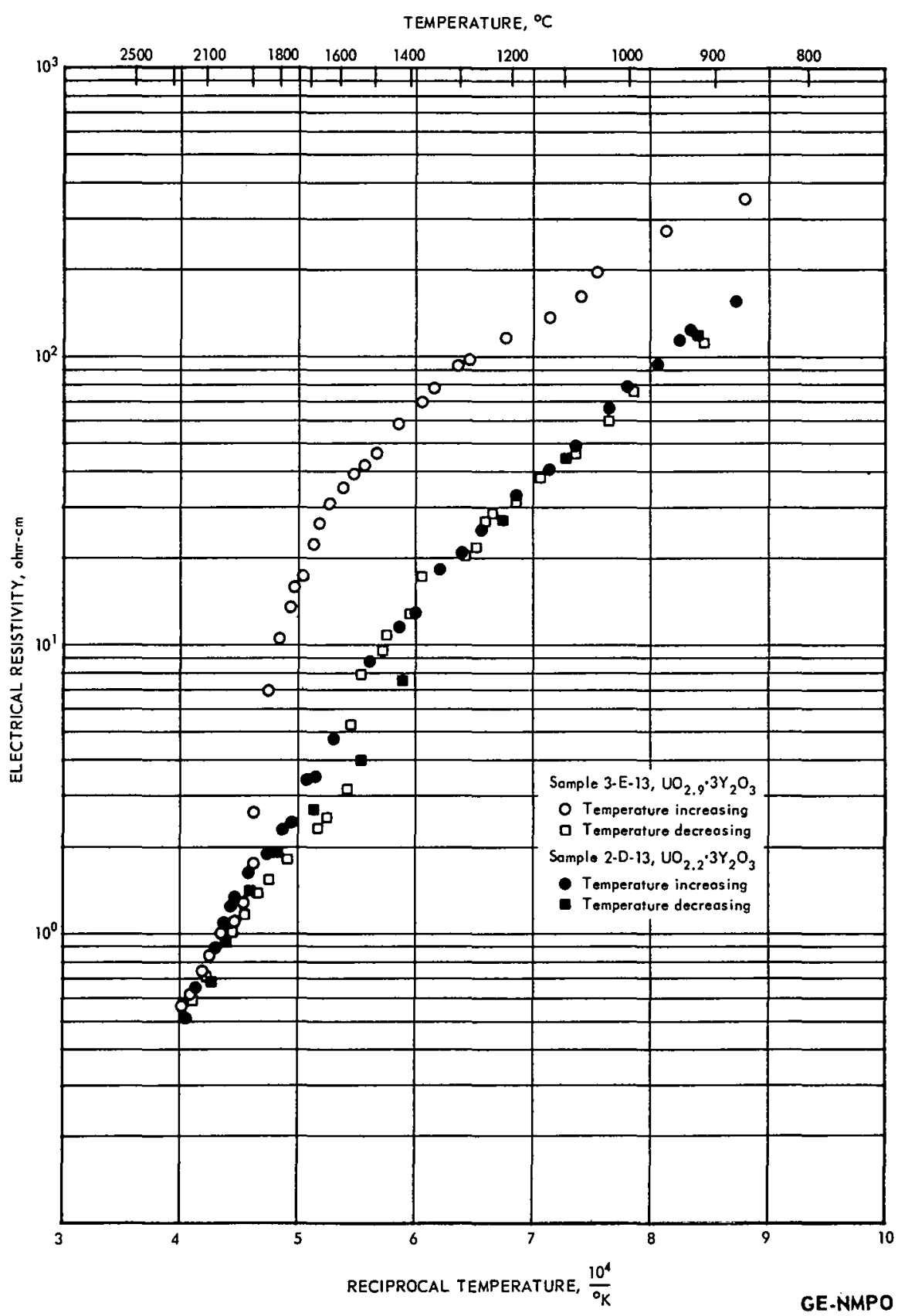

Fig. 3.29-Resistivity as a function of temperature for oxidized and reduced $\mathrm{UO}_{2+\mathrm{x}} \cdot 3 \mathrm{Y}_{2} \mathrm{O}_{3}$ measured in helium 
If the conductivity is partially ionic and partially electronic, the ionic transport number $\left(t_{i}\right)$ will be given by $E_{p} / E_{1}$, where $E_{p}$ is the measured emf developed and $E_{1}$ is the theoretical emf calculated from Equation (3.1). Thus, ionic and electronic contributions to the total conductivity may be determined.

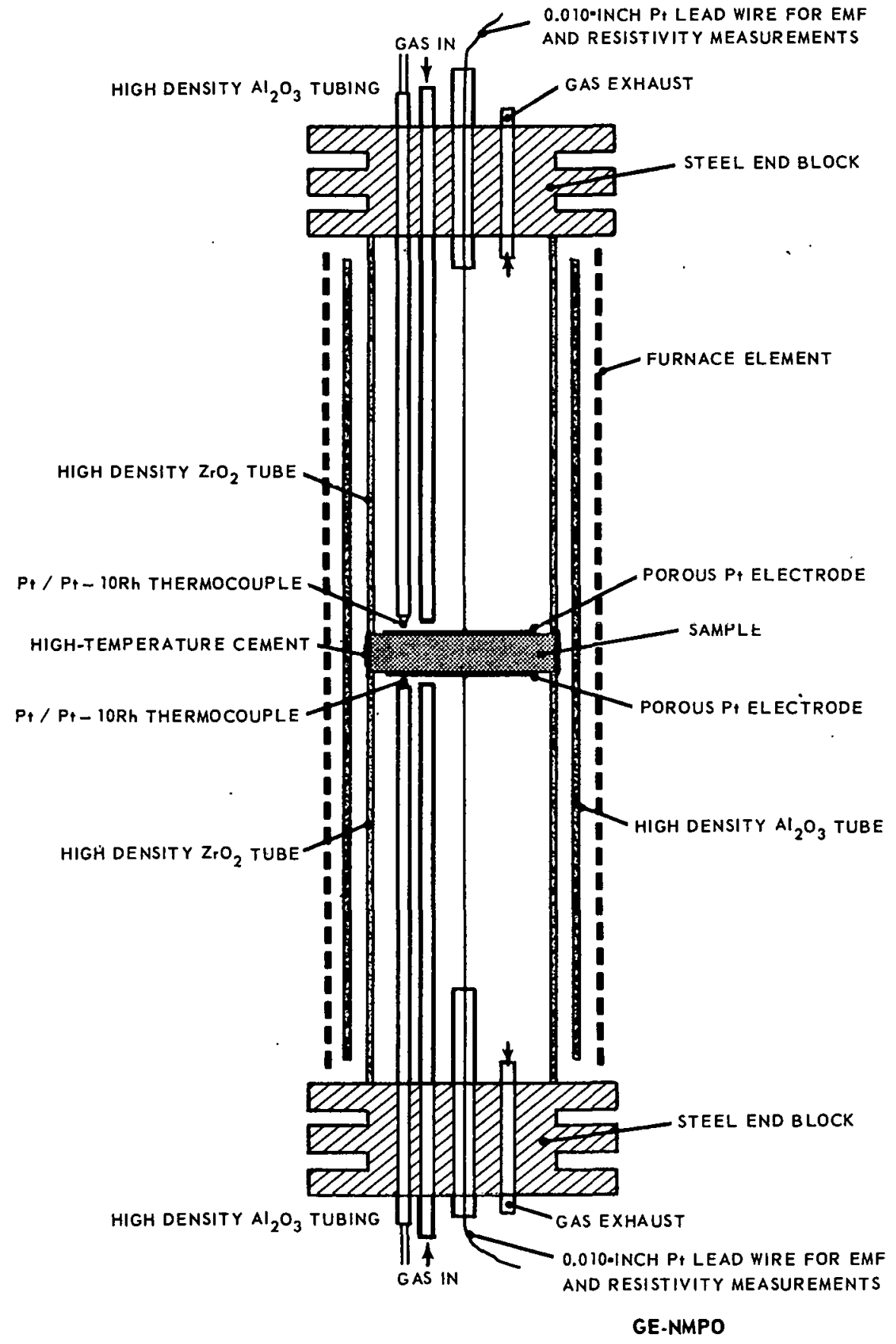

Fig. 3.30-Schematic diagram of apparatus for electrical resistivity and transport number measurements 
A preliminary run was conducted on polycrystalline cubic $\mathrm{ZrO}_{2}(19.6 \mathrm{~mole} \% \mathrm{CaO})$, which is essentially a completely ionic conductor. The test samples consisted of 2-centimeterdiameter wafers, 0.127 . centimeter thick with the electrical contact through porous platinum electrodes, 1 centimeter in diameter. The ionic transport numbers were measured by using air and oxygen at opposite electrodes. Interchanging the gases on the electrodes showed that the cell was reversible. Ionic transport numbers of 0.90 were measured between $1000^{\circ} \mathrm{C}$ and $1400^{\circ} \mathrm{C}, 10$ percent below the theoretical value for a purely ionic conductor. This low value is possibly a result of some small cracks in the sample which allowed some gas leakage.

Similar measurements were made on samples of $\mathrm{UO}_{2.9} \cdot 3 \mathrm{Y}_{2} \mathrm{O}_{3}$ and $2 \mathrm{UO}_{2.95} \cdot 3 \mathrm{Y}_{2} \mathrm{O}_{3}$. This latter sample was about 50 percent $R h I$ and 50 percent FCC. No measurable emf

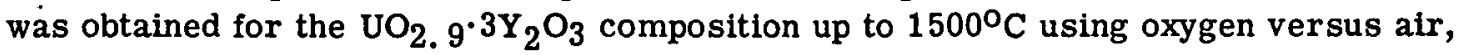
air versus $\mathrm{CO}_{2}$, and oxygen versus $\mathrm{CO}_{2}$. Similarly, no emf was observed for the $2 \mathrm{UO}_{2} .95^{\circ} 3 \mathrm{Y}_{2} \mathrm{O}_{3}$ composition for temperatures up to $900{ }^{\circ} \mathrm{C}$. Examination showed that the samples were sound after the measurements. Consequently, it is concluded that these materials are essentially electronic conductors with little or no ionic contribution in these temperature ranges.

The electrical conductivity of the $\mathrm{UO}_{2.9} \cdot 3 \mathrm{Y}_{2} \mathrm{O}_{3}$ and the $2 \mathrm{UO}_{2.95} \cdot 3 \mathrm{Y}_{2} \mathrm{O}_{3}$ compositions was measured in oxygen and air to $1500^{\circ} \mathrm{C}$ and $1000^{\circ} \mathrm{C}$, respectively. The results are plotted in Figure 3.31. Both a-c and d-c measurements of the conductivity were made. Polarization effects, resulting in an increase in electrical resistance with time, were observed during $d-c$ measurements. Consequently, the data in Figure 3.31 were plotted from a-c measurements employing an impedance bridge with 1000 cycles per second, a-c current. The conductivity of the $\mathrm{UO}_{2} .9 \cdot 3 \mathrm{Y}_{2} \mathrm{O}_{3}$ composition increases from $2.8 \times 10^{-5}$ $(\mathrm{ohm}-\mathrm{cm})^{-1}$ at $300^{\circ} \mathrm{C}$ to $9 \times 10^{-3}(\mathrm{ohm}-\mathrm{cm})^{-1}$ at $1480^{\circ} \mathrm{C}$. The activation energy for this process is $0.80 \mathrm{ev}$, comparable to the activation energy for the extrinsic range for $\mathrm{UO}_{2}+\mathrm{x}$ as reported by Williardson et al. ${ }^{21}$ The conductivity for the $2 \mathrm{UO}_{2} .95 \cdot 3 \mathrm{Y}_{2} \mathrm{O}_{3}$ composition increases from $3.5 \times 10^{-4}(\mathrm{ohm}-\mathrm{cm})^{-1}$ at $150^{\circ} \mathrm{C}$ to $3.25 \times 10^{-2}(\mathrm{ohm}-\mathrm{cm})^{-1}$ at $1000^{\circ} \mathrm{C}$, with an activation energy of $0.60 \mathrm{ev}$.

Electrical conductivity and transport numbers were measured on the $2 \mathrm{UO}_{3-\mathrm{x}} \cdot 3 \mathrm{Y}_{2} \mathrm{O}_{3}$ composition to $1500^{\circ} \mathrm{C}$ in air and in oxygen atmospheres. The measurements to $1500^{\circ} \mathrm{C}$ for the mixed phase sample are plotted in Figures 3.32 and 3.33. A second sample (B) of the same composition as specimen $A$ was prepared as face-centered-cubic phase (FCC) solid solution; the data for this sample to $1500^{\circ} \mathrm{C}$ are shown in Figures 3.34 and 3. 35 .

The $\mathrm{X}$-ray and chemical analyses data for the two specimens of the $2 \mathrm{UO}_{3-\mathrm{x}} \cdot 3 \mathrm{Y}_{2} \mathrm{O}_{3} \mathrm{com}$ positions are given in Table 3.4.

The transport measurements given in Figures 3.33 and 3.35 show that there is a partial Ionic contribution to the conductivity which amounts to about 5 percent at $1000^{\circ} \mathrm{C}$ and reaches about 14 percent at $1500^{\circ} \mathrm{C}$.

The conductivity measurements to $1500^{\circ} \mathrm{C}$ on the specimen $\mathrm{A}(50 \% \mathrm{FCC} ; 50 \% \mathrm{Rh} \mathrm{I})$ are shown in Figure 3.32. From $1000^{\circ} \mathrm{C}$ to $1500^{\circ} \mathrm{C}$, there is a complex region in which conductivity decreases with increasing temperature. Discontinuous behavior of this kind usually signifies a transition region from extrinsic to intrinsic mode of conductivity in semiconductors. This is, however, the temperature range in which transport measurements indicate that mixed conductivity becomes a significant factor. Thus the region of discontinuous behavior probably represents a region of complexity in which there is decreasing electronic conductivity and increasing ionic contributions to the total conductivity. Further studies in oxidizing atmospheres at temperatures above $1500^{\circ} \dot{\mathrm{C}}$ are required to clarify the mechanisms involved. 


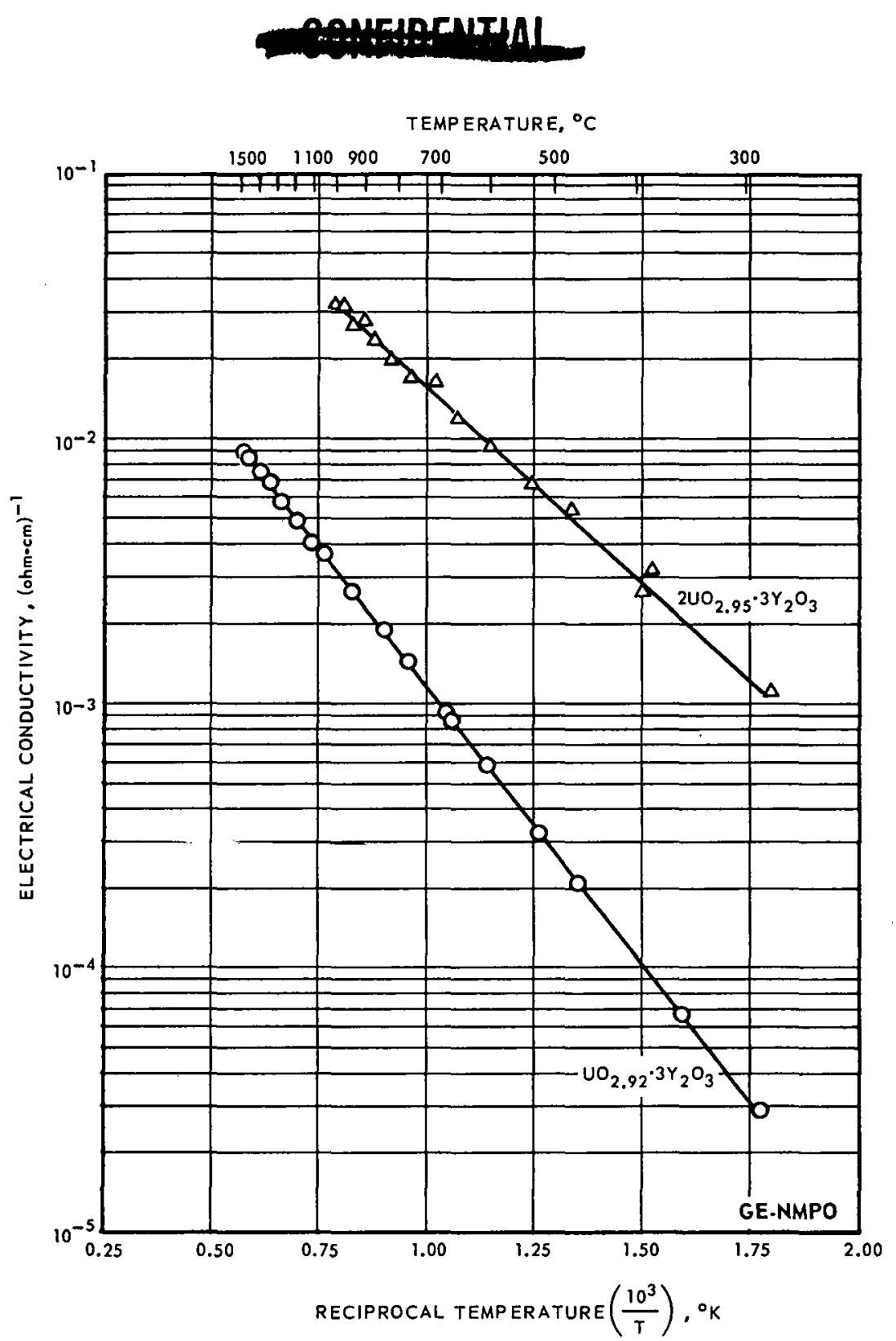

Fig. 3.31 - Flectrical conductivity as a function of reciprocal temperature for two compositions in the $\mathrm{UO}_{2}-\mathrm{UO}_{3}-\mathrm{Y}_{2} \mathrm{O}_{3}$ system

TABLE 3.4

X-RAY DIFFRACTION AND CHEMICAL ANALYSES OF CONDUCTIVITY SPECIMENS

\begin{tabular}{ccc}
\hline Sample & Phases Present & Oxygen-To-Uranium Ratio \\
\hline A & $50 \% \mathrm{FhI}+$ & 2.94 \\
& $50 \% \mathrm{FCC}$ & \\
B & $100 \%$ FCC & 3.00 \\
\hline
\end{tabular}




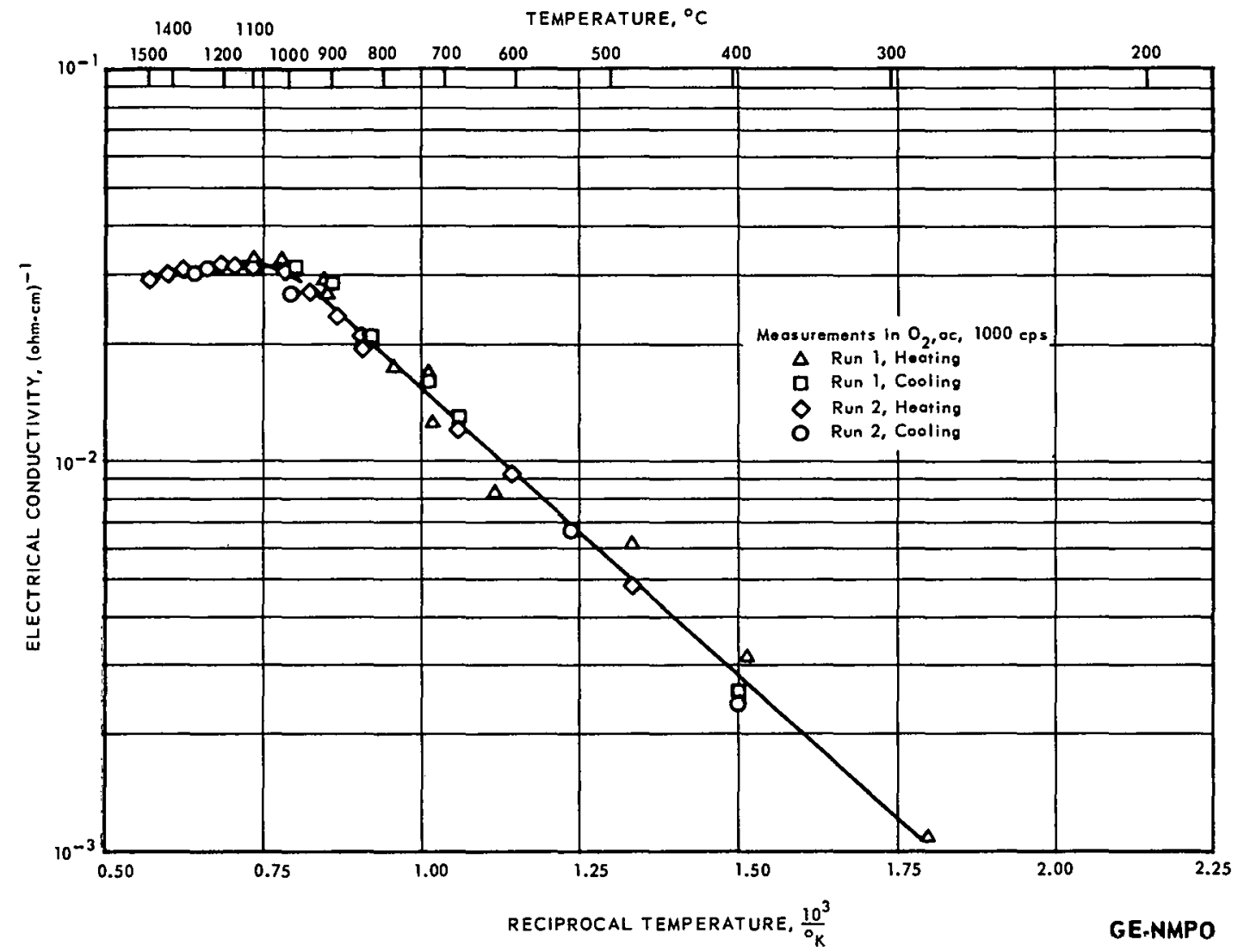

Fig. 3.32-Electrical conductivity versus reciprocal temperature for $2 \mathrm{UO}_{3-\mathrm{x}} \cdot 3 \mathrm{Y}_{2} \mathrm{O}_{3}$ (initially $\sim 50 \% \mathrm{FCC}-50 \% \mathrm{Rh} \mathrm{I}$ )

Fig. 3.33-lonic conductivity as a function of temperature for $2 \mathrm{UO}_{3-\mathrm{x}} \cdot 3 \mathrm{Y}_{2} \mathrm{O}_{3}$ (initially $50 \%$ FCC, $50 \%$ Rh I)

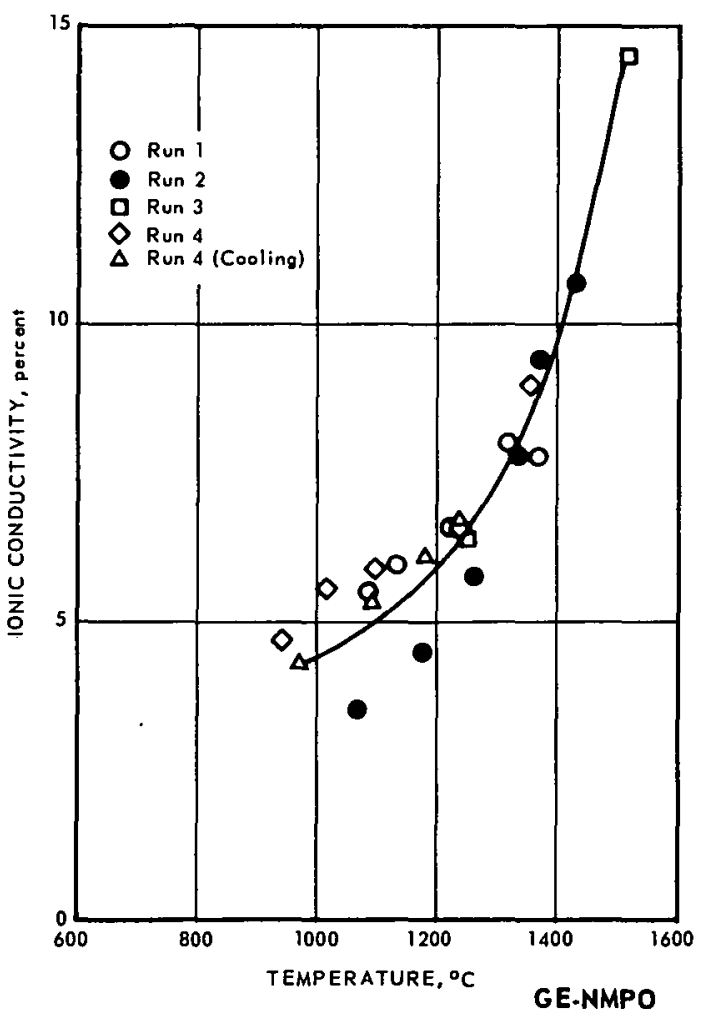




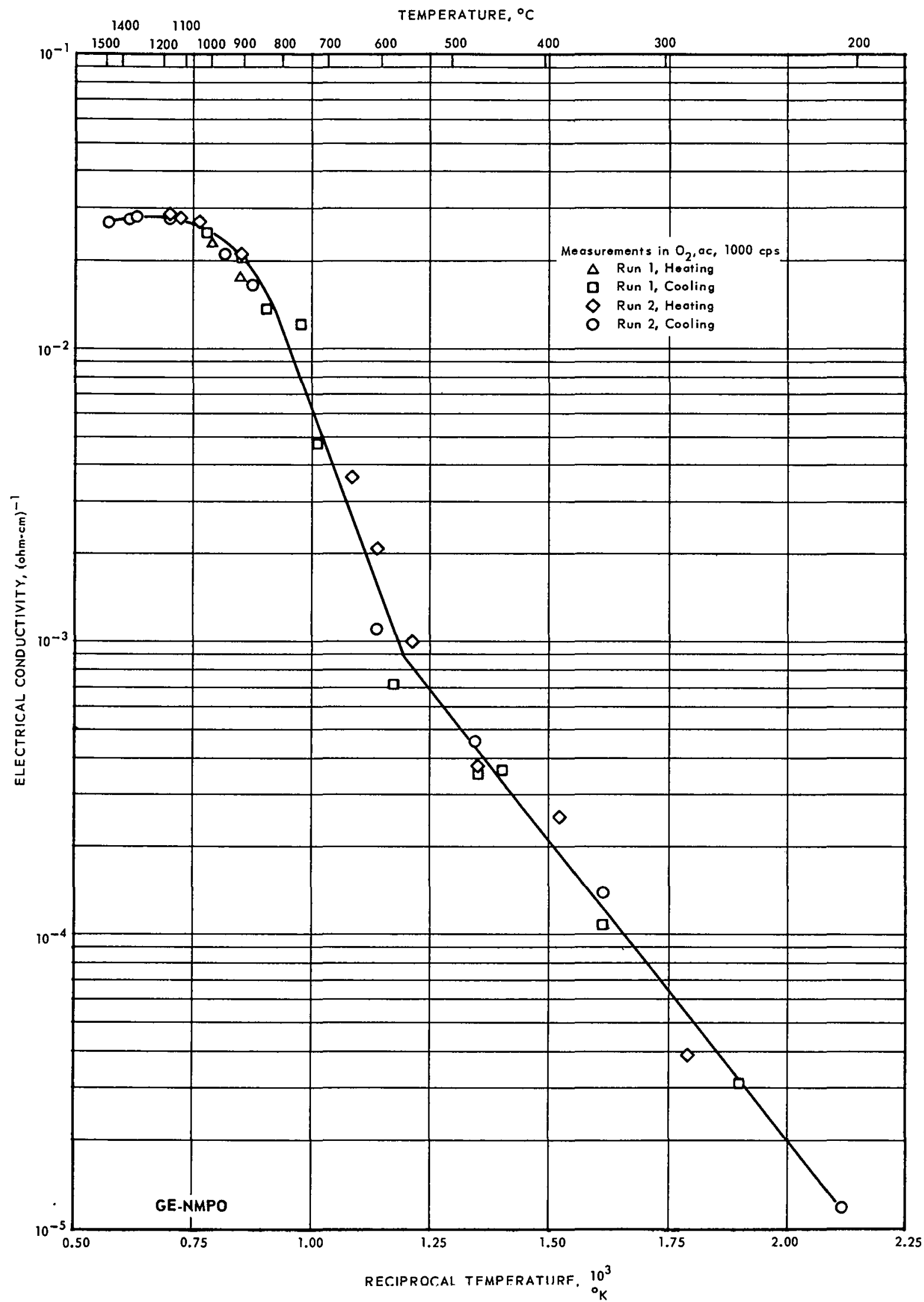

Fig. 3.34-Electrical conductivity versus reciprocal temperature for $2 \mathrm{UO}_{3-\mathrm{x}} \cdot 3 \mathrm{Y}_{2} \mathrm{O}_{3}$ (initially $100 \% \mathrm{FCC}$ ) 


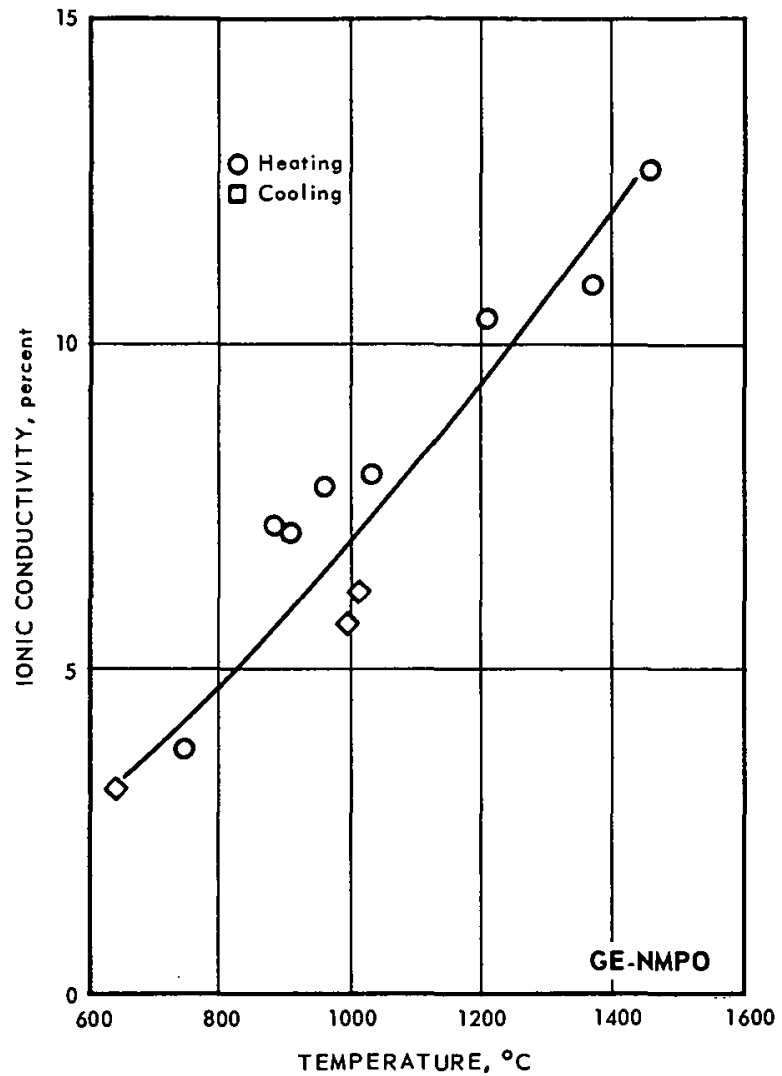

Fig. 3.35-Ionic conductivity as a function of temperature for $2 \mathrm{UO}_{3-\mathrm{x}} \cdot 3 \mathrm{Y}_{2} \mathrm{O}_{3}$ (initially $100 \%$ FCC)

An activation energy of $0.6 \mathrm{ev}$ was calculated assuming the relationship, $\sigma=\mathrm{A}$ exp-E/2kT, for the straight line portion of the $\log \sigma$ versus $1 / T$ curve. Activation energies of this magnitude are typical of extrinsic conductivity. For example, typical activation energies for $\mathrm{UO}_{2+\mathrm{x}}$ range from 0.4 to $0.9 \mathrm{ev}^{21}$ for the extrinsic semiconductivity region. The activation energy for intrinsic semiconductivity in similar oxide systems generally is of the order of several electron volts; the activation energy for $\mathrm{UO}_{2+x}$, for instance, is approximately $4.0 \mathrm{ev}$ for intrinsic semiconductivity. 21

Figure 3.34 shows the plot of $\log \sigma$ versus $1 / \mathrm{T}$ for the face-centered-cubic specimen. Three distinct regions are observed in this plot. Between $200^{\circ} \mathrm{C}$ and approximately $600^{\circ} \mathrm{C}$, the curve is linear as the temperature is increased. The activation energy for the conduction process in this range is $0.8 \mathrm{ev}$. At approximately $600^{\circ} \mathrm{C}$, there is a break in the curve and the rate of increase in conductivity is significantly higher. The "activationenergy" over this range is $2.10 \mathrm{ev}$. Above $780^{\circ} \mathrm{C}$, the curvature previously discussed for specimen $A$ is also observed. Thermogravimetric analyses of the $2 \mathrm{UO}_{3-\mathrm{x}} \cdot 3 \mathrm{Y}_{2} \mathrm{O}_{3} \mathrm{com}-$ position (Figure 3.36) indicates that the region of rapid change in conductivity corresponds to the temperature range $\left(\sim 600^{\circ} \mathrm{C}\right)$ at which the fluorite solid solution initially undergoes significant reversible oxygen dissociation.

Oxygen dissociation effects are not observed as readily in the $\mathrm{Rh}$ I structure, which appears to be an ordered structure which does not readily dissociate upon heating in air or oxygen. The FCC structure, on the other hand, gives off oxygen on heating in air or oxygen and consequently would be expected to show some marked changes in electrical properties if oxygen deficiencies (1.e., defects or vacancies in the oxygen sublattice) 


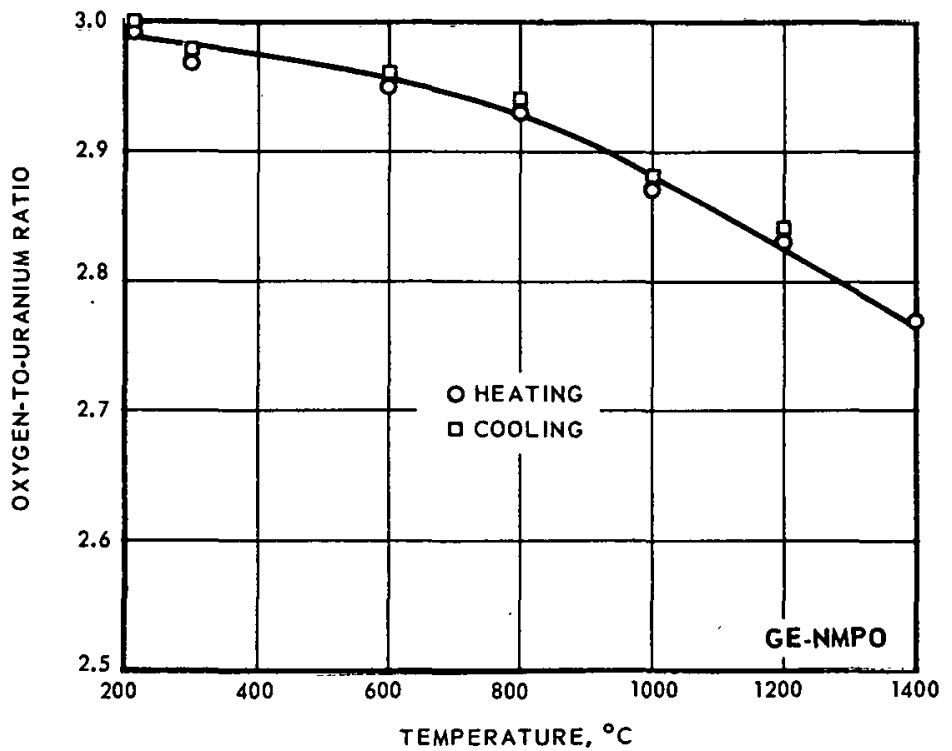

Fig. 3.36 - Thermogravimetric analysis of $2 \mathrm{UO}_{3-\mathrm{x}} \cdot 3 \mathrm{Y}_{2} \mathrm{O}_{3}$ (FCC) showing reversible oxygen dissociation upon thermal cycling in air

contribute significantly to the extrinsic semiconducting properties of this system. This effect is observed in Figure 3.34 of the $2 \mathrm{UO}_{3}-\mathrm{x} \cdot 3 \mathrm{Y}_{2} \mathrm{O}_{3}$ composition where, as indicated above, the break in the $\log \sigma$ versus $1 / T$ curve corresponds to the temperature region $\left(\sim 600^{\circ} \mathrm{C}\right)$ in which appreciable oxygen dissociation occurs. This temperature range is well below that at which appreciable cation mobility is observed in phase equilibria studies; hence, the behavior appears to be associated with the degree of oxygen dissociation. Fully oxidized $2 \mathrm{UO}_{3} \cdot 3 \mathrm{Y}_{2} \mathrm{O}_{3}$ has an oxygen-to-metal ratio of $15: 8$ or 1.875 . This ratio is sufficiently reduced when the temperature exceeds approximately $600^{\circ} \mathrm{C}$ to introduce further oxygen vacancies in the oxygen sublattice with corresponding enhanced electrical conductivity. This effect was found to be reversible.

No such enhanced conductivity effect was observed in either the $\mathrm{UO}_{3} \cdot 3 \mathrm{Y}_{2} \mathrm{O}_{3}$ composition ( $100 \% \mathrm{Rh} \mathrm{I}$ ) or in the initial measurement on the $2 \mathrm{UO}_{3}-\mathrm{x} \cdot 3 \mathrm{Y}_{2} \mathrm{O}_{3}$ sample (50\% $\mathrm{Rh} \mathrm{I}-50 \%$ FCC). These results are in agreement with the oxygen dissociation effects discussed above since thermogravimetric studies ${ }^{16}$ show the rhombohedral phase (Rh I) does not undergo oxygen dissociation to the degree observed in the fluorite solid solution.

Vapor Pressure

Transpiration measurements were made to establish the vapor pressure of $\mathrm{UO}_{3}$ over $\mathrm{UO}_{2.8} \cdot 3 \mathrm{Y}_{2} \mathrm{O}_{3}$ as a function of temperature, using oxygen and air as carrier gases. These data are shown in Figure 3.37. Vapor pressures were found to range from $8.04 \times 10^{-9}$ atmosphere at $1400^{\circ} \mathrm{C}$ to $1.78 \times 10^{-6}$ atmosphere at $1710^{\circ} \mathrm{C}$. The upper limit of the vapor pressure of yttria was found to be $10^{-9}$ atmosphere at $1700^{\circ} \mathrm{C}$. The vapor pressure of UO 3 above $\mathrm{U}_{3} \mathrm{O}_{8}$ in air or oxygen varies from $4 \times 10^{-4}$ atmosphere at $1540^{\circ} \mathrm{C}$ to $1 \times 10^{-6}$ atmosphere at $1200^{\circ} \mathrm{C}$.

\section{Heat Capaclty}

Heat capacity measurements of the $\mathrm{UO}_{2+\mathrm{x}} \cdot 3 \mathrm{Y}_{2} \mathrm{O}_{3}$ composition were made to $2000^{\circ} \mathrm{C}$ by employing a drop technique in conjunction with an adiabatic calorimeter. Enthalpy data obtained on both oxidlzed and reduced specimens are plotted as a function of temperature In Figure 3.38. These data shuw that, as expected, the heat capacity $\left(C_{p}\right)$ is not appreci- 


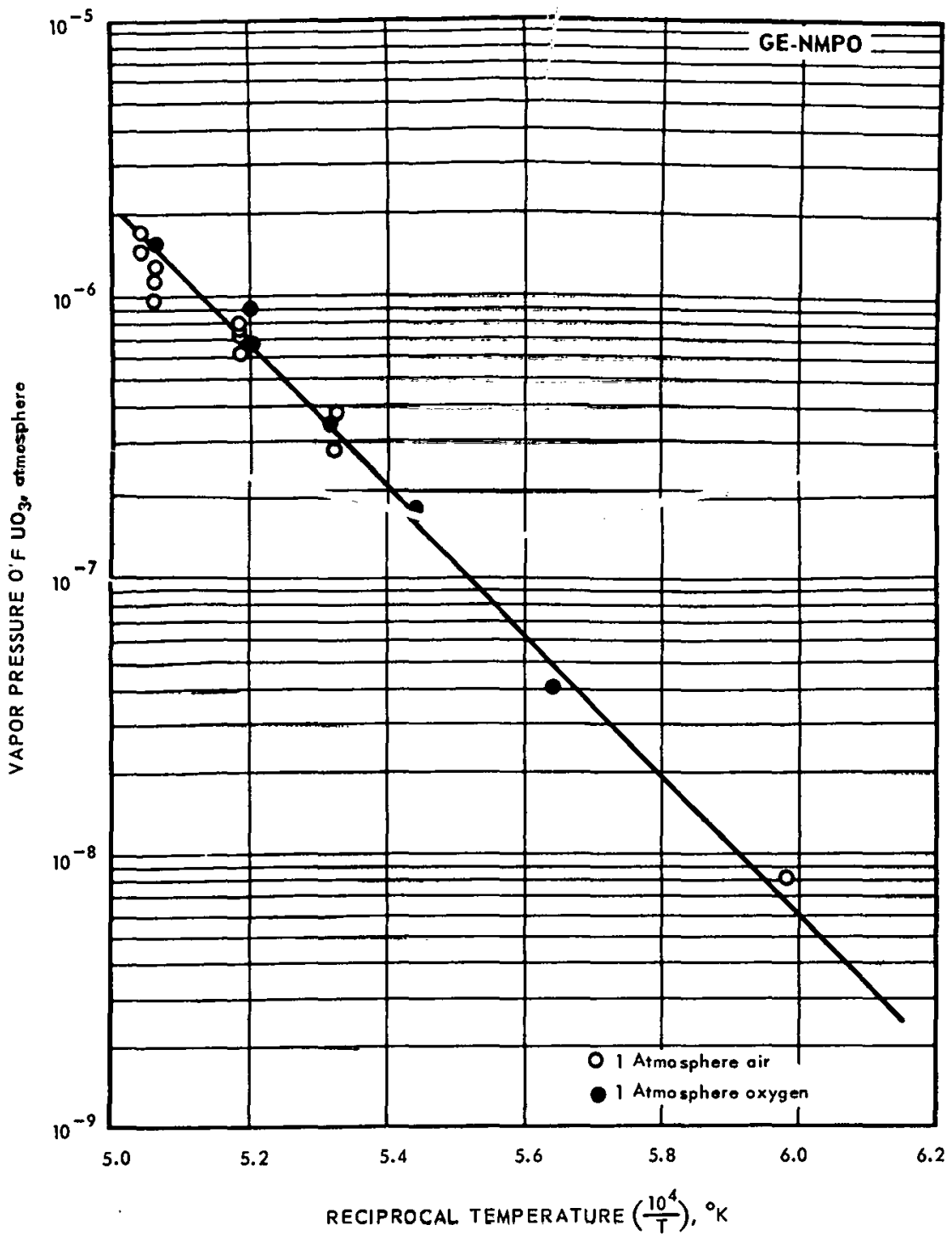

Fig. 3.37 - Vapor pressure of $\mathrm{UO}_{3}$ over $\mathrm{UO}_{2+\mathrm{x}} \cdot 3 \mathrm{Y}_{2} \mathrm{O}_{3}$

ably influenced by the oxidation state of the material. The following equations give the enthalpy - temperature and heat capacity - temperature relationships for these data.

$$
\mathrm{H}_{298}^{\mathrm{T}}=-31.04+0.101 \mathrm{~T}+5.97 \times 10^{-6} \mathrm{~T}^{2}+2.98 \times 10^{-9} \mathrm{~T}^{3},\left(\mathrm{~T}={ }^{\circ} \mathrm{K}\right)
$$

Thus,

$$
C_{p}=0.101+11.94 \times 10^{-6} \mathrm{~T}+8.94 \times 10^{-9} \mathrm{~T}^{2}
$$

The maximum deviation of the experimental data from that calculated using Equation (3.3) was 2.13 percent. Except for two points in the lower temperature range $\left(\sim 530^{\circ} \mathrm{K}\right)$, agreement was within 1 percent. Table 3.5 tabulates some values for both mean $\mathrm{C}_{\mathrm{p}}\left(\mathrm{H}_{298}^{\mathrm{T}} / \Delta \mathrm{T}\right)$ and $C_{p}$ calculated from Equations (3.2) and (3.3), respectively.

The same experimental technique was used to measure the heat capacity of $\mathrm{UO}_{2}$ between $930^{\circ} \mathrm{C}$ and $1925^{\circ} \mathrm{C}$. The data for these experiments are plotted in Figure 3.38. Table 3.6 summarizes the mean $C_{p}$ for these data. 


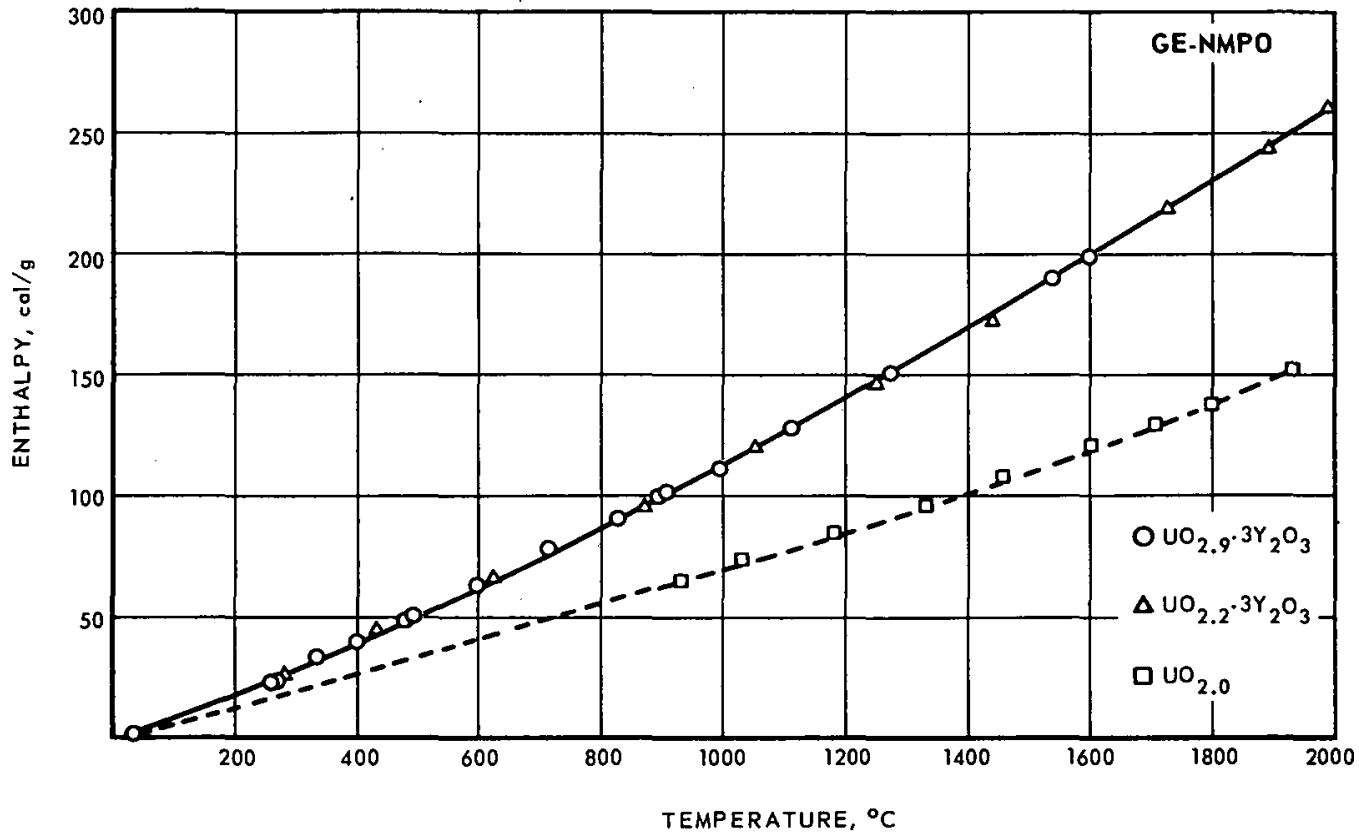

Fig. 3.38-Enthalpy of $\mathrm{UO}_{2+\mathrm{x}} \cdot 3 \mathrm{Y}_{2} \mathrm{O}_{3}$ and $\mathrm{UO}_{2}$ as a function of temperature

TABLE 3.5

HEAT CAPACITY OF $\mathrm{UO}_{2+\mathrm{x}^{-}} 3 \mathrm{Y}_{2} \mathrm{O}_{3}$

\begin{tabular}{ccc}
\hline $\begin{array}{c}\text { Temperature, } \\
{ }^{\circ} \mathrm{C}\end{array}$ & $\begin{array}{r}\text { Heat Capacity }\left(\mathrm{C}_{\mathrm{p}}\right), \\
\text { cal } / \mathrm{g}-{ }^{\circ} \mathrm{C}\end{array}$ & $\begin{array}{r}\text { Mean Heat Capacity }\left(\overline{\mathrm{C}_{\mathrm{p}}}\right) \text {, } \\
\text { cal/g-OC }\end{array}$ \\
\hline 200 & 0.109 & 0.106 \\
400 & 0.113 & 0.108 \\
600 & 0.118 & 0.111 \\
800 & 0.124 & 0.114 \\
1000 & 0.131 & 0.116 \\
1200 & 0.138 & 0.120 \\
1400 & 0.146 & 0.123 \\
1600 & 0.154 & 0.126 \\
1800 & 0.164 & 0.130 \\
2000 & 0.174 & 0.134 \\
\hline
\end{tabular}

TABLE 3.6

HEAT CAPACITY OF $\mathrm{UO}_{2}$

\begin{tabular}{cc}
\hline $\begin{array}{c}\text { Temperature, } \\
{ }^{\circ} \mathrm{C}\end{array}$ & $\begin{array}{c}\text { Mean Specific Heat }\left(\overline{\mathrm{C}_{\mathrm{p}}}\right) \\
\text { cal } / \mathrm{g}-{ }^{\circ} \mathrm{C}\end{array}$ \\
\hline 929 & 0.0724 \\
1030 & 0.0736 \\
1183 & 0.0744 \\
1327 & 0.0743 \\
1454 & 0.0760 \\
1606 & 0.0769 \\
1702 & 0.0783 \\
1000 & 0.0788 \\
1924 & 0.0810 \\
\hline
\end{tabular}




\subsection{MECHANICAL PROPERTIES}

Modulus of Rupture of $\mathrm{UO}_{2}+x^{*} \cdot 3 \mathrm{Y}_{2} \mathrm{O}_{3}$

Modulus of rupture tests were made to evaluate the strength properties of $\mathrm{UO}_{2+\mathrm{x}} \cdot 3 \mathrm{Y}_{2} \mathrm{O}_{3}$ in the oxidized state $(x=0.9)$ and the reduced state $(x=0.2)$. The specimens consisted of extruded and sintered round rods 8.9 to 12.7 centimeters ( 3.5 to 5 inches) in length, center less ground to 0.610 centimeter $(0.240 \mathrm{inch})$ in diameter. The rods were broken at room temperature by using a 4-point loading on a 7.6-centimeter (3-inch) span. Additional data were obtained utilizing the broken sections on a 4.4- or 3.2-centimeter $(1-3 / 4-$ or 1-1/4-inch) span with either a 3- or 4-point loading. The ram travel was 0.15 centimeter (0.060 inch) per minute.

A statistical analysis of the data (Table 3.7) showed that the oxygen-sintered samples had a higher modulus of rupture strength than the hydrogen-sintered samples. Table 3.7 shows that a 3-point loading produced consistently higher values than a 4-point loading in agreement with previous work on BeO. ${ }^{23}$ It should be noted that decreasing the spanyielded higher apparent modulus of rupture values.

A portion of the rods that were oxygen sintered was reduced in hydrogen at $1700^{\circ} \mathrm{C}$ for 48 hours. Three of these reduced samples were again oxidized by heating in air for 24 hours at $1450^{\circ} \mathrm{C}$. The modulus of rupture data (Table 3.7) indicate a possible small decrease in strength in the reduced specimens.

Modulus of rupture measurements were also made on $\mathrm{UO}_{2.9} \cdot 3 \mathrm{Y}_{2} \mathrm{O}_{3}$ specimens, 0.51 by 0.51 by 5.08 centimeters, sintered in oxygen to 99.7 to 99.8 percent of theoretical density. Measurements made at room temperature, $1000^{\circ}, 1250^{\circ}$, and $1500^{\circ} \mathrm{C}$ in air are summarized in Table 3.8. These measurements were made using a 3-point loading on a 4.44centimeter span with a 0.20 -centimeter head travel per minute.

Microscopic examination of the fracture edges of modulus of rupture specimens indicates that transgranular fracture occurs both in the oxidized and reduced specimens. A typical fracture is shown in Figure 3.39. Figures 3.40 and 3.41, show the fracture patterns of $\mathrm{BeO}$ and $\mathrm{Al}_{2} \mathrm{O}_{3}$, respectively, and are included for comparison purposes. Both of these latter materials show greater strength, and the photomicrographs show less transgranular fracture. All modulus of rupture specimens were examined by Zyglo and radiographic methods and found to be free of fissures and voids prior to breaking.

Room-temperature and elevated-temperature modulus of rupture tests were conducted on coextruded $\mathrm{BeO}$ hexagonal tubes with 0.076-centimeter $(0.003-\mathrm{inch})$ inside diameter cladding of $\mathrm{UO}_{2} .9 \cdot 3 \mathrm{Y}_{2} \mathrm{O}_{3}$ sintered in air at $1600^{\circ} \mathrm{C}$ for 2 hours. The tube dimensions were 0.67 centimeter $(0.264 \mathrm{inch})$ across flats with a 0.48 -centimeter $(0.189$-inch) inside diameter. The tubes were broken with a 4-point loading on 7.6-centimeter (3-inch) span with $0.15-$ centimeter ( 0.060 inch) per minute beam travel. Eleven tubes were tested at room temperature and had an average modulus of rupture of $1850 \mathrm{~kg} / \mathrm{cm}^{2}(26,300 \mathrm{psi})$ with a standard deviation of $176 \mathrm{~kg} / \mathrm{cm}^{2}(2,500 \mathrm{psi})$. Nine tubes that were tested at $1370^{\circ} \mathrm{C}$ had an average modulus of rupture of $1322 \mathrm{~kg} / \mathrm{cm}^{2}(18,800 \mathrm{psi})$ with a $112 \mathrm{~kg} / \mathrm{cm}^{2}(1,600 \mathrm{psi})$ standard deviation.

\section{Elastic Properties}

The temperature dependence of the dynamic modulus was measured from room temperature to $1510^{\circ} \mathrm{C}$ for the $\mathrm{UO}_{2.9} \cdot 3 \mathrm{Y}_{2} \mathrm{O}_{3}$ composition. These data are presented in Figures $3.42,3.43$, and 3.44 and show that both the dynamic modulus of elasticity and dynamic shear modulus decrease with temperature. Calculated Poisson's ratio remains essentially constant at 0.3 . The test specimen was 10 centimeters ( 4 inches) long and 0.63 centimeter $(1 / 4$ inch) in diameter and was suspended in the furnace on two platinum wire loops at the 
TABLE 3. 7

MODULUS OF RUPTURE OF OXYGEN- AND HYDROGEN-SINTERED UO ${ }_{2+x} \cdot 3 \mathrm{Y}_{2} \mathrm{O}_{3}$ COMPOSTTION

AND OF OXYGEN-SINTERED, REDUCED, AND REOXIDIZED SAMPLES

\begin{tabular}{|c|c|c|c|c|c|c|c|c|c|c|c|c|c|}
\hline \multicolumn{2}{|c|}{ Test Condition } & \multicolumn{3}{|c|}{$\begin{array}{c}\text { Oxygen-Sintered } \mathrm{UO}_{2+x} \cdot 3 \mathrm{Y}_{2} \mathrm{O}_{3} \\
1750^{\circ} \mathrm{C} \text { For } 3 \text { Hours }\end{array}$} & \multicolumn{3}{|c|}{$\begin{array}{c}\text { Hydrogen-Sintered } \mathrm{UO}_{2+\mathrm{x}} \cdot 3 \mathrm{Y}_{2} \mathrm{O}_{3} \\
1700^{\circ} \mathrm{C} \text { For } 12 \text { Hours }\end{array}$} & \multicolumn{3}{|c|}{$\begin{array}{l}\text { Hydrogen-Reduced } \mathrm{UO}_{2+x} \cdot 3 \mathrm{Y}_{2} \mathrm{O}_{3} \\
1700^{\circ} \mathrm{C} \text { For } 48 \text { Hours }\end{array}$} & \multicolumn{3}{|c|}{$\begin{array}{c}\text { Air-Reoxidized } \mathrm{UO}_{2+x^{-3}} \mathrm{Y}_{2} \mathrm{O}_{3} \\
1450^{\circ} \mathrm{C} \text { For } 24 \text { Hours }\end{array}$} \\
\hline $\begin{array}{l}\text { Loading } \\
\text { Point }\end{array}$ & $\begin{array}{l}\text { Span, } \\
\text { in. }\end{array}$ & $\begin{array}{l}\text { No. Of Samples } \\
\text { Tested }\end{array}$ & $\begin{array}{l}\text { Average, } \\
\mathrm{kg} / \mathrm{cm}^{2}\end{array}$ & $\begin{array}{l}\text { Standard } \\
\text { Deviation }\end{array}$ & $\begin{array}{l}\text { No. Of Samples } \\
\text { Tested }\end{array}$ & $\begin{array}{l}\text { Average, } \\
\mathrm{kg} / \mathrm{cm}^{2}\end{array}$ & $\begin{array}{l}\text { Standard } \\
\text { Deviation }\end{array}$ & $\begin{array}{l}\text { No. Of Samples } \\
\text { Tested }\end{array}$ & $\begin{array}{l}\text { Average, } \\
\mathrm{kg} / \mathrm{cm}^{2}\end{array}$ & $\begin{array}{l}\text { Standard } \\
\text { Deviation }\end{array}$ & $\begin{array}{l}\text { No. Of Samples } \\
\text { Tested }\end{array}$ & $\begin{array}{l}\text { Average, } \\
\mathrm{kg} / \mathrm{cm}^{2}\end{array}$ & $\begin{array}{l}\text { Standard } \\
\text { Deviation }\end{array}$ \\
\hline 4 & 3 & 23 & 940 & 100 & 16 & 749 & 116 & & & & & & \\
\hline 4 & 1.75 & 15 & 993 & 83 & 11 & 865 & 86 & & & & & & \\
\hline 3 & 1.75 & 26 & 1044 & 120 & 6 & 903 & 193 & & & & & & \\
\hline 3 & 1. 25 & 19 & 1132 & 80 & 15 & 984 & 124 & & & & & & \\
\hline 4 & 3 & & & & & & & 8 & 724 & 204 & 3 & 808 & 108 \\
\hline 3 & 1.75 & & & & & & & 9 & 963 & 234 & 3 & 1005 & 4 \\
\hline 3 & 1.25 & & & & & & & 8 & 1083 & 199 & 2 & 1111 & 30 \\
\hline
\end{tabular}



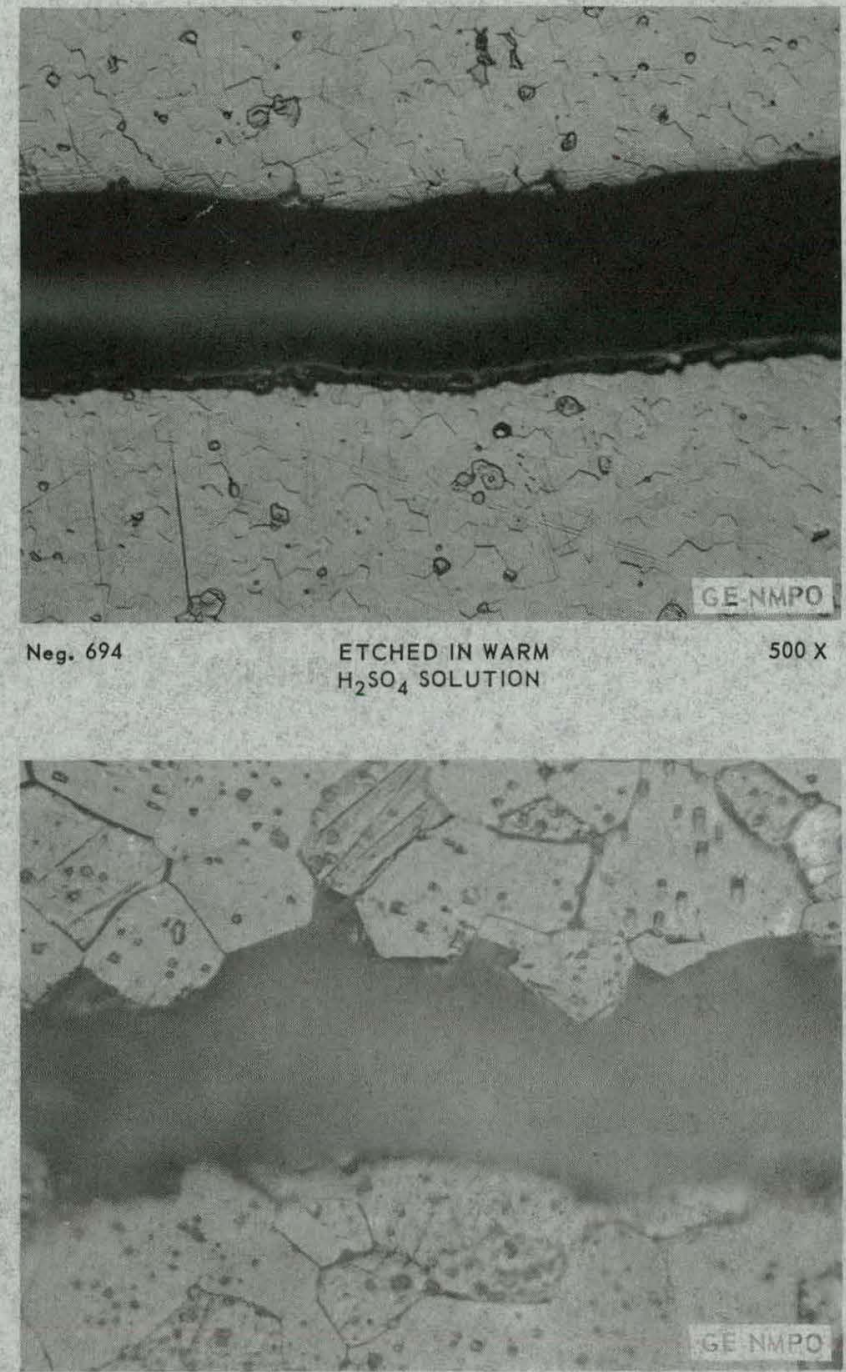

Neg. 692

\section{ETCHED IN WARM} $50 \%$ HF SOLUTION

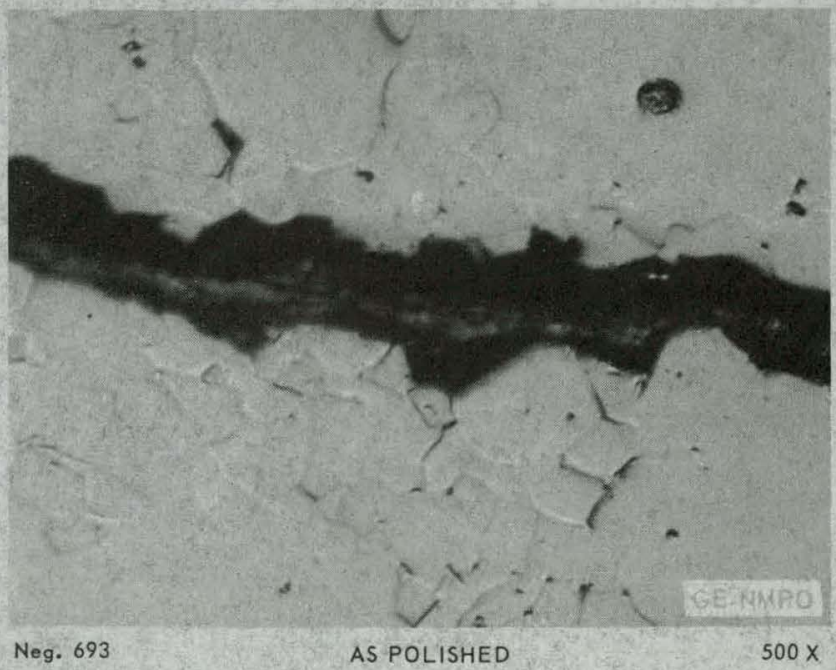

Fig. 3.39-Transgranular fracture of $\mathrm{UO}_{2.9} \cdot 3 \mathrm{Y}_{2} \mathrm{O}_{3}$, sintered in $\mathrm{O}_{2}$ for 3 hours at $1750^{\circ} \mathrm{C}$

Fig. 3.40-Fracture pattern of UOX-grade beryllia plus 0.5 weight percent $\mathrm{MgO}$, sintered in hydrogen for 3 hours at $1540^{\circ} \mathrm{C}$
Fig. 3.41 - Fracture pattern of alumina (Linde A) plus 0.25 weight percent $\mathrm{MgO}$, sintered in hydrogen for 10 hours at $1700^{\circ} \mathrm{C}$ 
TABLE 3.8

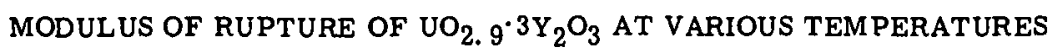

\begin{tabular}{cccr}
\hline Number of Specimens & Temperature, ${ }^{\circ} \mathrm{C}$ & $\begin{array}{c}\text { Average Modulus } \\
\text { Of Rupture, } \mathrm{kg} / \mathrm{cm}^{2}\end{array}$ & \multicolumn{1}{c}{$\begin{array}{c}\text { Spread } \\
\mathrm{kg} / \mathrm{cm}^{2}\end{array}$} \\
\hline 18 & Room Temperature & 1380 & $700-1830$ \\
4 & 1000 & 1360 & $1170-1660$ \\
4 & 1250 & 1260 & $800-1590$ \\
4 & 1500 & 1650 & $1450-1940$ \\
\hline
\end{tabular}

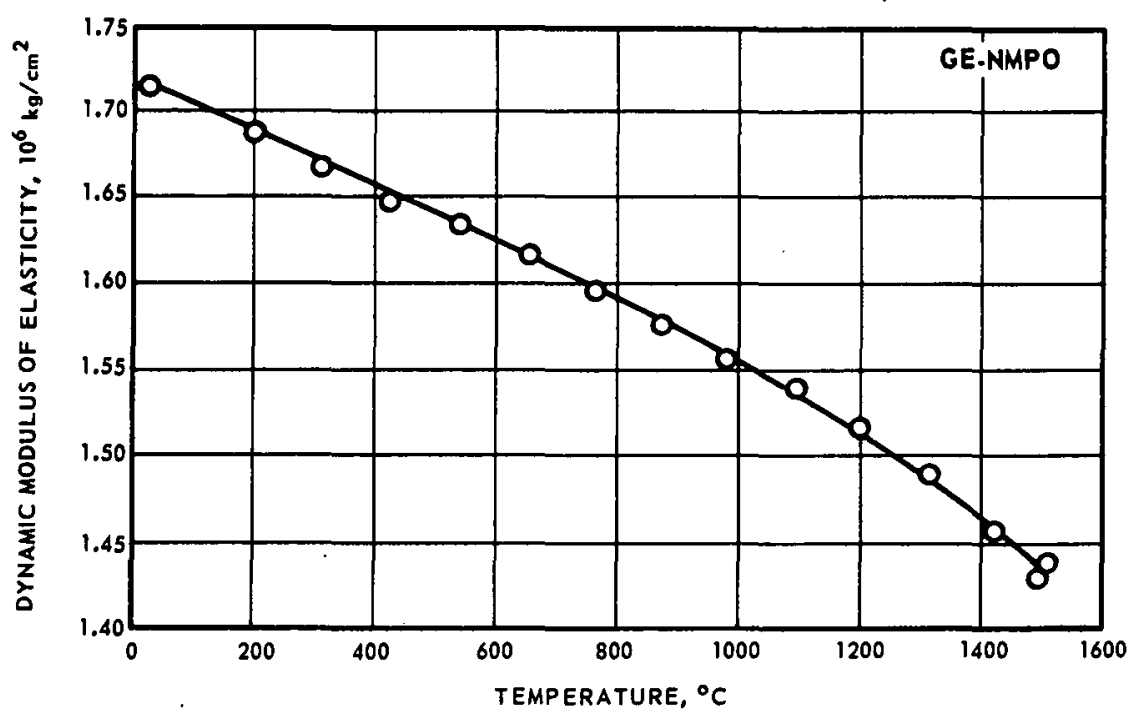

Fig. 3.42 - Dynamic modulus of elasticity versus temperature for $\mathrm{UO}_{2.9} \cdot 3 \mathrm{Y}_{2} \mathrm{O}_{3}$

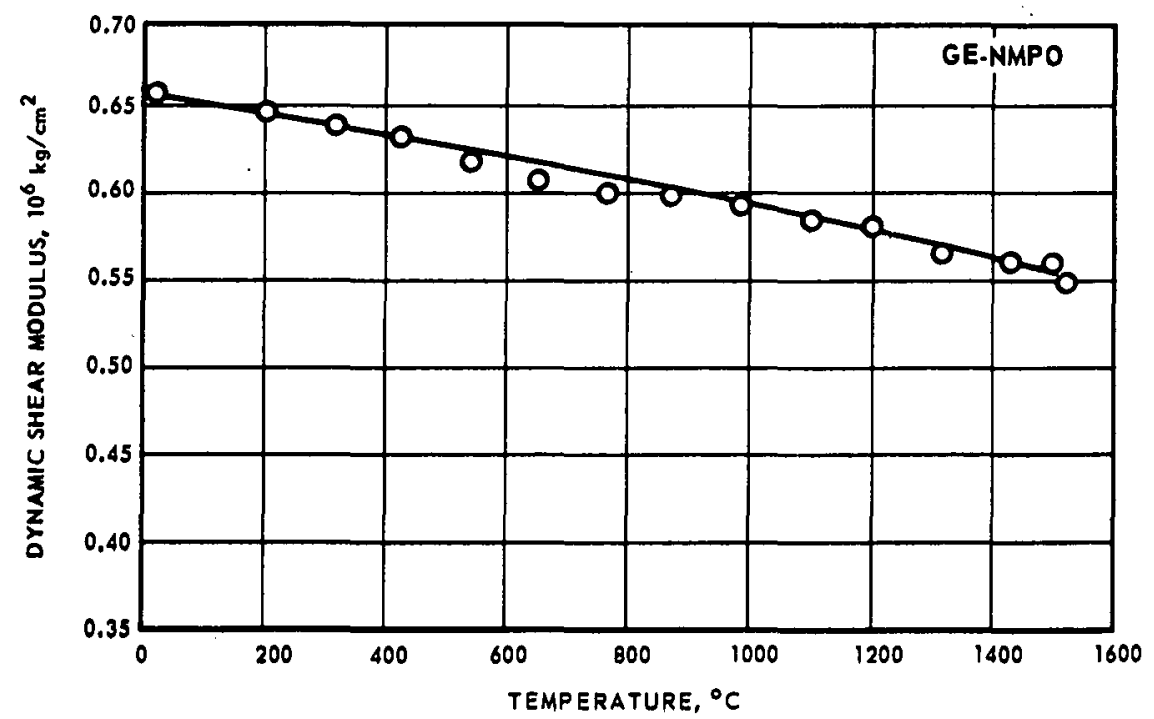

Fig. 3.43-Dynamic shear modulus versus temperature for $\mathrm{UO}_{2.9} \cdot 3 \mathrm{Y}_{2} \mathrm{O}_{3}$ 


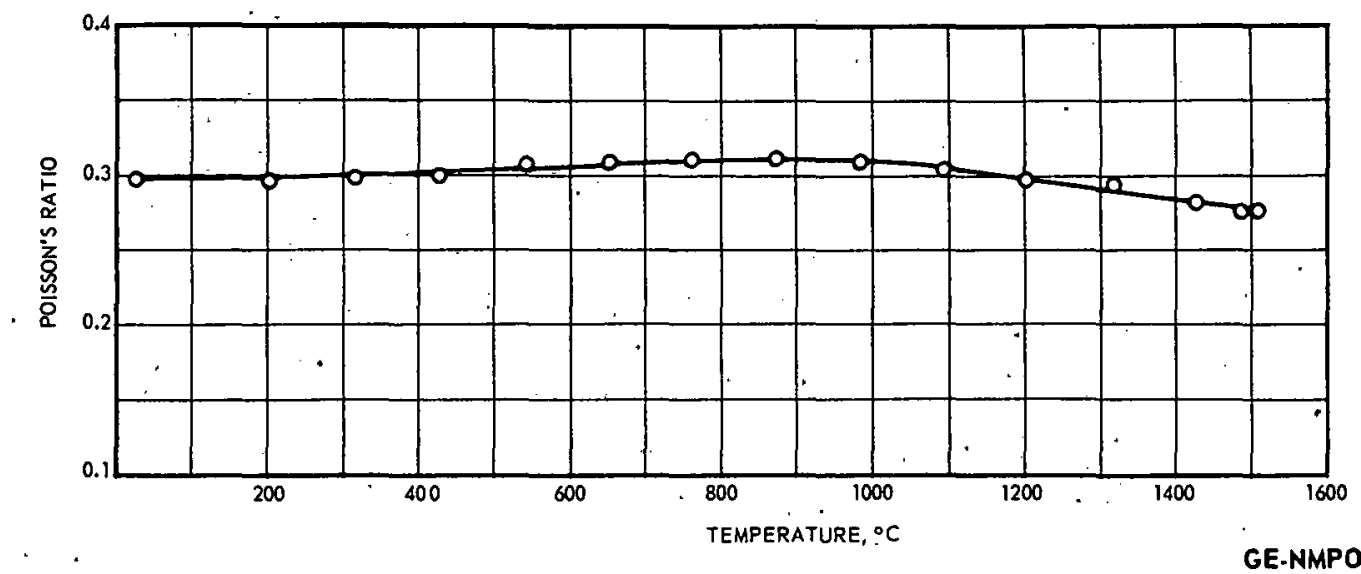

Fig. 3.44-Calculated Poisson's ratio versus temperature for $\mathrm{UO}_{2.9} \cdot 3 \mathrm{Y}_{2} \mathrm{O}_{3}$

nodal points. One platinum wire was attached to an external crystal exciter and the other loop to an external crystal pickup. This arrangement permitted simultaneous measurement of the fundamental transverse and torsional frequencies.

\section{Compressive Creep .}

Compressive creep measurements were made on $\mathrm{UO}_{2} .9 \cdot 3 \mathrm{Y}_{2} \mathrm{O}_{3}$ samples: 0.5 by 0.5 by 2.5 centimeters $(0.2$ by 0.2 by $1.0 \mathrm{inch}$ ) having a density of 99.7 percent of theoretical: The total deformation after 100 hours at $1540^{\circ} \mathrm{C}$ in air was 0.43 percent for a load of 8.8 $\mathrm{kg} / \mathrm{cm}^{2}(125 \mathrm{psi})$ and 0.50 percent for a load of $17.6 \mathrm{~kg} / \mathrm{cm}^{2}(250 \mathrm{ps})$.

\section{Thermal Stress Resistance}

Previous experience showed that a $\mathrm{BeO}$ homogeneous dispersion-type fuel element generally falls because of residual stresses induced upon cooling. ${ }^{24}$ By applying the fuel as an inside surface cladding to the $\mathrm{BeO}$, however, thermal gradients are greatly reduced. Thermal stress calculations were made comparing these two fuel element concepts at a power level of $150 \mathrm{~g}-\mathrm{cal} / \mathrm{cm}^{3}-\mathrm{sec}\left(10 \mathrm{Btu} / \mathrm{in} .{ }^{3}-\mathrm{sec}\right)$. The calculations (based on tube dimensions of 0.670 centimeter across flats, a 0.480 -centimeter bore, and a 0.008 -centimeter-thick cladding) are summarized in Table 3.9 and illustrate the marked advantage of concentrating the fuel as a cladding on the BeO. By concentrating the fuel at the surface, the important residual stresses are reduced from 1139 to $41 \mathrm{~kg} / \mathrm{cm}^{2}$ and elastic stress from 429 to $33 \mathrm{~kg} / \mathrm{cm}^{2}$.

Transient test methods ${ }^{24,25}$ (thermal shock) were utilized to test the $\mathrm{UO}_{2.9} \cdot 3 \mathrm{Y}_{2} \mathrm{O}_{3}$-clad $\mathrm{BeO}$ tubes because of the experimental difficulty of operating a non-nuclear steady-state thermal stress test that would simulate actual operating conditions of the fuel element; i. e., internal power generation uniformly distributed throughout the cladding only with all heat removed from the bore. Thermal stresses were imposed by heating the tube to equilibrium temperature and then passing room temperature air through the bore of the tube. Heat removal rates were determined by readings from thermocouples imbedded in the tube with measurements recorded on a high-response self-balancing recording potentiometer. The stress calculations (described previously ${ }^{25}$ ) assumed elastic behavior.

These tests showed that at $1370^{\circ} \mathrm{C}$ a stress in the BeO portion of $914 \mathrm{~kg} / \mathrm{cm}^{2}(13,000$ psi) was required to produce cracking, while at $1480^{\circ} \mathrm{C}$ a BeO stress level of 562 to 703 $\mathrm{kg} / \mathrm{cm}^{2}(8,000$ to $10,000 \mathrm{psi})$ produced cracking after repeated cycling. These values are greatly in excess of the calculated operating stresses as presented in Table 3.9. 
TABLE 3.9

COMPARISON OF CALCULATED STRESSES IN THREE TYPES OF FUEL ELEMENTS FOR A CONSTANT HEAT REMOVAL RATE OF $150 \mathrm{~g}$-cal/ch $-\mathrm{cec}$

\begin{tabular}{|c|c|c|c|c|c|}
\hline & \multirow{2}{*}{$\begin{array}{c}\text { Unclad Fueled BeO } \\
\text { Matrix }\end{array}$} & \multicolumn{2}{|c|}{$\mathrm{ZrO}_{2}$-Clad Fueled $\mathrm{BeO}$} & \multicolumn{2}{|c|}{$\mathrm{UO}_{2.9} \cdot 3 \mathrm{Y}_{2} \mathrm{O}_{3}-\mathrm{Clad} \mathrm{BeO}$} \\
\hline 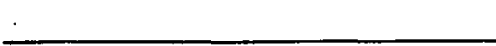 & & Matrix & Clad & Matrix & Clad \\
\hline Temperature gradlent, ${ }^{\circ} \mathrm{C}$ & 18.1 & 16.3 & 11.0 & 0.6 & 9.5 \\
\hline Maximum elastic stress, $\mathrm{kg} / \mathrm{cm}^{2}$ & $562 \mathrm{~T}^{\mathrm{a}}$ & $429 \mathrm{~T}$ & $703 \mathrm{~T}$ & $33 \mathrm{~T}$ & $155 \mathrm{~T}$ \\
\hline Maximum residual stress, $\mathrm{kg} / \mathrm{cm}^{2}$ & $1033 \mathrm{~T}$ & $1139 \mathrm{~T}$ & $337 \mathrm{C}^{\mathrm{b}}$ & $41 \mathrm{~T}$ & $260 \mathrm{~T}$ \\
\hline
\end{tabular}

$a_{T}$ - tenslle

${ }^{b} \mathrm{C}$ - compressive

There was no indication of fallure of the cladding or cladding-matrix interface which is confirmation of the excellent match of expansion characteristics of $\mathrm{BeO}$ and $\mathrm{UO}_{2.9} \cdot 3 \mathrm{Y}_{2} \mathrm{O}_{3}$ reported in an earlier section.

Analysis and experiments in thermal stress have used cracks as a method of determining the severity of thermal stress, although it must be recognized that cracking, espectally the type detectable only by fluorescent dye penetrants, would not necessarlly constitute fallure of a fuel element to perform tts desired function.

\section{4 IRRADIATION TESTS}

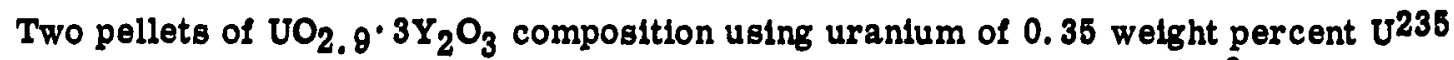
enrichment were irradiated in the ORR at a maximum temperature of $400^{\circ} \mathrm{C}$ to determine the effects of fast neutrons on microstructure, phase stabllity, and phy sical integrity of dense bodies of this composition. The total dosage of fast neutrons ( $>1 \mathrm{Mev}$ ) was 1020 nvt. No changes in specimen dimensions or density occurred during irradiation. Microscopic comparison of as-pollshed sections of both Irradiated and unirradiated samples revealed no observable cracks or other radiation-induced flaws. Samples etched in warm $\mathrm{H}_{2} \mathrm{SO}_{4}$ revealed a general overall tendency for the irradiated specimen to etch more heavily along grain boundaries than the unirradiated control specimen. Other than this etching effect, however, there were no detectable differences in grain size or microstructure between specimens.

The $\mathrm{X}$-ray diffraction analyses indicate that a crystallographic phase change from the ordered Rh I structure to a FCC structure occurred during irradiation. This change occurred without cracking or other physical disruption of the irradiated specimens.

Further irradiation tests to evaluate the fission product retention characteristics and effects of high burnup on stability of this fuel composition in a BeO-clad, coextruded tube are being conducted under Task 57068. 


\section{GOMTUUENIIAL}

\section{SUMMARY AND CONCLUSIONS}

The work performed during this program resulted in a tentative phase diagram for the $\mathrm{UO}_{2}-\mathrm{UO}_{3}-\mathrm{Y}_{2} \mathrm{O}_{3}$ system for temperatures up to $1700^{\circ} \mathrm{C}$. Four phases were identified in the system at temperatures between $1000^{\circ}$ and $1700^{\circ} \mathrm{C}$ : (1) $\mathrm{U}_{3} \mathrm{O}_{8} ;(2)$ a face-centered cubic solid solution; (3) a body -centered cubic solid solution; and (4) a rhombohedral phase of the composition $(\mathrm{U}, \mathrm{Y})_{7} \mathrm{O}_{12}$ ranging from 52.5 to 75 mole pereent $\mathrm{Y}_{2} \mathrm{O}_{3}$. The rhombohedral phase oxidizes to a second rhombohedral phase with a nominal composition (U, $\mathrm{Y})_{8} \mathrm{O}_{15}$ at temperatures below $1000^{\circ} \mathrm{C}$. This phase transforms to a FCC phase after heating in air above $1000^{\circ} \mathrm{C}$. The solubility of $\mathrm{UO}_{2}$ in the $\mathrm{BCC}$ phase is about 14 mole percent between $1000^{\circ}$ and $1700^{\circ} \mathrm{C}$ but decreases to 0 mole percent as the uranium approaches the hexavalent oxidation state. The solubility of $\mathrm{Y}_{2} \mathrm{O}_{3}$ in the $\mathrm{FCC}$ solid solution ranges from 0 to 50 mole percent $\mathrm{Y}_{2} \mathrm{O}_{3}$ under reducing conditions and from 33 to 60 mole percent $\mathrm{Y}_{2} \mathrm{O}_{3}$ under oxidizing conditions at $1000^{\circ} \mathrm{C}$.

At temperatures above $1000^{\circ} \mathrm{C}$, the FCC solid solution is limited by a filled fluorite lattice of composition $(\mathrm{U}, \mathrm{Y}) \mathrm{O}_{2}$. Oxidation at low temperatures $\left(<300^{\circ} \mathrm{C}\right)$ permits additional oxygen to be retained in the structure to a composition approaching (U, $\mathrm{Y}) \mathrm{O}_{2.25}$.

Fabrication of the $\mathrm{UO}_{2.9} \cdot 3 \mathrm{Y}_{2} \mathrm{O}_{3}$ composition has been straightforward. The material sinters to 99.5 percent of theoretical when the particle size of the starting powder is generally less than 5 microns in diameter. It has been cold-formed by pressing and by extrusion including co-extrusion with BeO.

The thermal stability of $\mathrm{UO}_{2.9} \cdot 3 \mathrm{Y}_{2} \mathrm{O}_{3}$ in an oxidizing atmosphere is excellent as compared to other $\mathrm{UO}_{2}$ carrying compositions. The material remains unchanged in air to $1700^{\circ} \mathrm{C}$ for times up to 500 hours. Longer times at this temperature and correspondingly shorter times at higher temperatures in air causes the material to lose uranium as $\mathrm{UO}_{3}$, in agreement with the measured vapor pressure of $\mathrm{UO}_{3}$ over the material.

The coextrusion of $\mathrm{UO}_{2.9} \cdot 3 \mathrm{Y}_{2} \mathrm{O}_{3}$ as a cladding on the inside diameter of $\mathrm{BeO}$ tubes shows that the material has potential for use as a high specific powder self-moderating fuel element. BeO was applied as a cladding to this fuel to minimize fission product release. It is to be noted that this sandwich-type fuel element of brittle materials is possible since the thermal expansion of $\mathrm{UO}_{2} .9 \cdot 3 \mathrm{Y}_{2} \mathrm{O}_{3}$ is very nearly the same as that for $\mathrm{BeO}$.

The physical and mechanical properties of $\mathrm{UO}_{2.9} \cdot 3 \mathrm{Y}_{2} \mathrm{O}_{3}$ are similar to those of $\mathrm{UO}_{2}$. The electrical conductance shows that the material is essentially an electronic conductor with possibly some ionic contribution at high temperatures. The modulus of rupture strength measurements show that $\mathrm{UO}_{2.9} \cdot 3 \mathrm{Y}_{2} \mathrm{O}_{3}$ is somewhat stronger than the same composition in the reduced state of $\mathrm{UO}_{2.2} \cdot 3 \mathrm{Y}_{2} \mathrm{O}_{3}$. Reoxidation, however, restores the material to about the original strength.

The results of this evaluation program indicate that the $\mathrm{UO}_{2}+\mathrm{x} \cdot 3 \mathrm{Y}_{2} \mathrm{O}_{3}$ fuel composition shows promise for application in reactor systems operating for several thousand hours in the temperature range from $1500^{\circ}$ to $1700^{\circ} \mathrm{C}$. Of particular interest is the fact that this 
composition is the only known high-temperature fuel material with such stability, being capable of operating in both oxidizing and reducing atmospheres and cycling between oxidizing and reducing atmospheres without catastrophic changes in strength or physical integrity. Furthermore, the $\mathrm{UO}_{2.9} \cdot 3 \mathrm{Y}_{2} \mathrm{O}_{3}$ fuel composition as an internal fuel cladding on a tubular BeO element shows particular promise for high specific power reactor applications. 


\section{REFERENCES}

1. Franz Hund, U. Peetz, and G. Kottenhahn, "System Yttrium Oxide-Uranium Oxide $\left(\mathrm{U}_{3} \mathrm{O}_{8}\right), "$ Zeitschrift Fur Anorganische und Allgemeine Chemie, Vol. 278, 1955, pp. $184-191$.

2. E. J. Felten and E. A. Aitken, "The Mechanism and Kinetics of the Formation of $\mathrm{UO}_{2 .}$ 90-6YO 1.5 ," Journal of Inorganic and Nuclear Chemistry, Vol. 24, 1962, pp. 35-43.

3. G. A. Chase, "On the Existence of a Compound in the System Yttrium-UraniumOxygen," Acta Crystallography, Vol. 15, 1962, p. 91.

4. R. Collongues, M. Perez y Jerba, and J. Lefevre, "On the Equilibrium Phase Diagram of the Systems; $\mathrm{ZrO}_{2}$-Rare Earth Oxides," Bulletin of Society of Chemistry, France, 1961 , p. 70.

5. Franz Hund and U. Peetz, "Concerning Additional Fluorite Phases in the Mixed Oxides of Rare Earths with Uranium. Investigation of Systems: $\mathrm{La}_{2} \mathrm{O}_{3}, \mathrm{Sm}_{2} \mathrm{O}_{3}, \mathrm{Yb}_{2} \mathrm{O}_{3}$, $\mathrm{Sm}_{2} \mathrm{O}_{3}$ with $\mathrm{U}_{3} \mathrm{O}_{8}, "$ Zeitschrift Fur Anorganische und Allgemeine Chemie, Vol. 271, 1952, pp. 6-16.

6. James D. McCullough and J. D. Briton, "Rare Earth Oxide Systems: Ce ${ }^{I V}-\mathrm{Nu}^{\mathrm{III}}$, $\mathrm{Ce}^{\mathrm{IV}}-\mathrm{Pr} \mathrm{III}, \mathrm{Ce}^{\mathrm{IV}}-\mathrm{Pr}^{\mathrm{IV}}, \mathrm{Pr}^{\mathrm{IV}}-\mathrm{Nd}{ }^{\mathrm{III}}$," Journal of American Chemical Society, Vol. 74, 1950, pp. 1386-1390.

7. James D. McCullough and J. D. Briton, "X-ray Studies of Rare Earth Oxide Systems, II: The Oxide System: $\mathrm{Ce}^{\mathrm{IV}}-\mathrm{Sm}^{\mathrm{III}}, \mathrm{Ce}^{\mathrm{IV}}-\mathrm{Y}^{\mathrm{II}}, \mathrm{Pr}^{\mathrm{IV}}-\mathrm{YIII}$, and Pr $\mathrm{Pr}_{-}^{\mathrm{III}}$, "Journal of American Chemical Society, Vol. 74, 1952, pp. 5225-5227.

8. J. Stuart Anderson, I. F. Ferguson, and L. E. J. Roberts, "Anionic Vacancies in Fluorite-Type Oxides," Journal of Inorganic and Nuclear Chemistry, Vol. 1, 1955, pp. 340-341.

9. I. F. Ferguson and P. Fogg, "The Oxides of Uranium. Part VIII: The System Uranium Dioxide-Yttria," Journal of American Chemical Society, Vol. 726, 1957, p. 3679.

10. D. C. Hill, "Phase Relations and Crystal Chemistry in the System Uranium OxideLanthanum Oxide," Journal of American Ceramic Society, Vol. 45, 1962, p. 258.

11. W. B. Wilson, C. A. Alexander, and A. F. Gerds, "Stabilization of $\mathrm{UO}_{2}$," Journal Inorganic and Nuclear Chemistry, Vol. 20, 1961, p. 242.

12. L. Eyring and N. C. Baenziger, "Structure and Related Properties of the Oxides of Praseodymium," Journal of Applied Physics, Vol. 33, 1962, pp. 428-433.

13. N. C. Baenziger, H. A. Eick, H. S. Schuldt, and L. Eyring, "Terbium Oxides, III. X-ray Diffractions Studies of Several Stable Phases," Journal of American Chemical Society, Vol. 83, 1961, pp. 2219-2223.

14. J. Belle, Editor, Uranium Dioxide: Properties and Nuclear Applications, Superintendent of Documents, Washington 25, D. C., pp. 232-270.

15. S. Aronson and J. Belle, "The Nature of Non-Stoichiometry in Urania-Base Solid Solutions," Westinghouse Electric Corporation, WAPD-T-1294, March 1961.

16. E. F. Juenke, "A Thermogravimetric Study of the Oxidation of Urania-Yttria Solid Solutions," GE-NMPO, July 13, 1961.

17. R. Broz and A. A. Clavel, "Evaluation of Vibratory Ball Milling for Comminuting F-116," GE-ANPD, DC 61-3-122, March 23, 1961. 
18. D. G. Salyards, "Results of Some Laboratory Water Vapor Corrosion Tests of BeO," GE-ANPD, APEX-760, September 1961.

19. "Pluto Quarterly Report No. 13," University of California, UCRL-7079, (SRD), October 4, 1962, p. 153.

20. W. D. Kingery, J. Francl, R. L. Coble, and T. Vasetos, "Thermal Conductivity (X) Data for Several Pure Oxide Materials Corrected to Zero Porosity," Journal of American Ceramic Society, Vol. 37, No. 2, February 1954, p. 107.

21. Carl Wagner, "Beitragzur Theurie des Anlaufvorgangs," Zeitschrift Fur Physik. Chemie, Vol. B21, 1933, p. 25, and "Galvanische Zellen mit festen Elektrolyten mit gemischter Stromleitung," Zeitschrift Fur Elektrochemie, Vol. 60, 1956, p. 4.

22. R. K. Williardson, J. W. Moody, and H. L. Goering, "The Electrical Properties of Uranium Oxides," Journal of Inorganic and Nuclear Chemistry, Vol. 6, 1958, pp. 19-33.

23. J. E. McConnelee, "Modulus of Rupture Testing Methods Evaluation," GE-ANPD, DC 59-12-20, December 1, 1959.

24. "Ceramic Reactor Materials," GE-ANPD, APEX-914 (SRD), June 1962, pp. 182-211.

25. B. A. Chandler and J. B. McConnelee, "Thermal Stress Evaluation of Ceramic Fuel Elements," GE-NMPO, TM 63-4-2, April 1, 1963, submitted for publication in the Journal of Nuclear Materials. 


\section{ADVANCED TECHNOLOGY SERVICES \\ GENERAL (86) ELCTRIC}

